\title{
ANÁLISE MORFOLÓGICA E ESTUDO DOS SIALÓLITOS POR MEIO DAS MICROSCOPIAS ÓPTICA E DE POLARIZAÇÃO
}

ROSÁRIO DE ARRUDA MOURA ZEDEBSKI

\begin{abstract}
Dissertação apresentada à Faculdade de Odontologia de Bauru da Universidade de São Paulo, como parte dos requisitos para obtenção do título de Mestre em Odontologia, área de Patologia Bucal.
\end{abstract}

(Edição revisada)

BAURU

2003 


\section{ANÁLISE MORFOLÓGICA E ESTUDO DOS SIALÓLITOS POR MEIO DAS MICROSCOPIAS ÓPTICA E DE POLARIZAÇÃO}

ROSÁRIO DE ARRUDA MOURA ZEDEBSKI

Dissertação apresentada à Faculdade de Odontologia de Bauru da Universidade de São Paulo, como parte dos requisitos para obtenção do título de Mestre em Odontologia, área de Patologia Bucal.

Orientador: Professor Doutor Luís Antônio de Assis Taveira

(Edição revisada)

BAURU 


\section{Ficha Técnica:}

Rosário de Arruda Moura Zedebski: concepção original, execução, digitação e fotomicrografia.

Luís Antônio de Assis Taveira: concepção original, orientação e revisão final. Alberto Consolaro: concepção original, fotomicrografia e co-orientação.

José Roberto Pereira Lauris: orientação da análise estatística.

Edson Miguel Zedebski: formatação e digitação.

Valdir João Afonso: revisão final e vernáculo.

Maria Cristina Carrara Felippe: auxílio administrativo e técnico.

Fátima Aparecida Silveira: serviços laboratoriais.

Centro de cópias Toshiba: serviço de cópias e encadernação.

\section{ZEDEBSKI, Rosário de Arruda Moura}

Z22a Análise morfológica e estudo dos sialólitos através das microscopias óptica e de polarização/ Rosário de Arruda Moura Zedebski.-- Bauru, 2003. xvi , 108 p. : il. ; $30 \mathrm{~cm}$.

Dissertação (Mestrado) -- Faculdade de Odontologia de Bauru. Universidade de São Paulo.

Orientador: Prof. Dr. Luís Antônio de Assis Taveira

Co-orientador: Prof. Dr. Alberto Consolaro

Autorizo, exclusivamente para fins acadêmicos e científicos, a reprodução total ou parcial desta dissertação/tese, por processos fotocopiadores e outros meios eletrônicos.

Assinatura:

Bauru, 26 de junho de 2003.

Aprovado pelo Comitê de Ética em Pesquisa da Faculdade de Odontologia de BaurutUSP.

Protocolo: 010/2003.

Data: 26 de fevereiro de 2003. 


\section{ROSÁRIO DE ARRUDA MOURA ZEDEBSKI}

07 de janeiro de 1963

Ponta Grossa - Paraná

Filiação

$1982-1985$

$1986-2000$

$1996-2000$

$1997-1998$

$1997-1999$

$1998-2000$

$2001-2003$

Associações
Data e local de nascimento

Amaury Coelho de Arruda Moura

Lígia Nadal de Arruda Moura

Curso de Graduação em Odontologia pela Universidade Estadual de Ponta Grossa UEPG

Atuação como cirurgiã-dentista em Consultório particular, clínica geral e cirurgia

Estágio como cirurgiã auxiliar na área de Cirurgia e Traumatologia Bucomaxilofacial no Hospital Vicentino - Ponta Grossa

Professora auxiliar convidada do Curso de Aperfeiçoamento em Cirurgia da Escola de Aperfeiçoamento Profissional da Associação Brasileira de Odontologia de Ponta Grossa

Estágio como cirurgiã auxiliar na área de Cirurgia e Traumatologia Bucomaxilofacial na Santa Casa de Misericórdia - Ponta Grossa

Estágio Supervisionado na disciplina de Cirurgia e Traumatologia Bucomaxilofacial da Universidade Estadual de Ponta Grossa - UEPG

Mestrado em Odontologia, área de Patologia Bucal, na Faculdade de Odontologia de Bauru - USP

Associação Brasileira de Odontologia 
"O débil, acovardado, indeciso e servil não conhece, nem pode conhecer, o generoso impulso que guia aquele que confia em si mesmo, e cujo prazer não é o de ter conseguido a vitória, senão de se sentir capaz de conquistá-la!"

W. Shakespeare 
Dedico esse trabalho ao meu esposo Edson Miguel, pelo amor, paciência, apoio e compreensão incondicionais, combustível fundamental para esta conquista. 
"Disse uma vez: a vida me espanta. E o eco respondeu-me: canta!"

Botrel 


\section{AGRADECIMENTOS}

Ao Professor Doutor Luís Antônio de Assis Taveira,

pela orientação deste trabalho, pela paciência, confiança, estímulo e amizade, o meu reconhecimento e, com muito carinho, o meu muito obrigado! 
Ao Professor Doutor Alberto Consolaro, pela coorientação deste trabalho, pela oportunidade, amizade e exemplo de rigor científico, o meu reconhecimento e o meu muito obrigado! 
Às Professoras Doutora Denise Tostes Oliveira e

Doutora Vanessa Soares Lara, pela amizade e apoio constantes, o meu reconhecimento e o meu muito obrigado! 


\section{À MINHA FAMÍLIA}

Ao meu esposo Edson Miguel pela constante prova de amor em jamais cercear meus ideais, em nome da realização do "nosso" projeto de vida.

Aos meus pais, Amaury e Lígia, que além do infinito amor, tiveram a ousadia e a bravura de nos ensinar não apenas com palavras, mas com seus exemplos.

Às minhas irmãs, Rita, Rosana e Giovana, pelo constante apoio, pelo carinho e pela nossa união.

Aos meus Príncipes e Princesas, pelo amor e pela confiança incondicional.

Aos meus sogros, Josafat e Izidora, pela compreensão, pelo carinho e pelas orações. 


\section{AOS MEUS AMIGOS E COLEGAS}

Ao meu amigo Washington Rodrigues Camargo, pelo apoio, por confiar em mim e me ensinar a dizer "Hoje vai ser um lindo dia!"...

Aos amigos Luciana Dorochenko Martins e Maurício Zardo, pelo incentivo constante e por nossa preciosa amizade.

Aos amigos e colegas Valdomiro, Rosa, Carolina e Lídia, pelo convívio e pelo aprendizado.

Aos funcionários da Patologia da FOB-USP, Valdir João, Maria Cristina, Fátima Aparecida e Bernadete, pela acolhida, pela paciência e pelo sorriso amigo.

A todos os colegas Pós-graduados e Pós-graduandos, Jazzmina, Braz, Sandra, Daniel, Simone, Fernanda, Mariza, Jussara, Tarcília, Telma, Laurindo e Mirian, também, Maria Renata, Andréa, João Adolfo, Tânia, Maria Fernanda e Aline, e ainda aos recém chegados Tiago, Lidiane, Renata, Renato, Camila, Renata C., Luciana e Bethânia, o meu muito obrigado pelo convívio e pela troca de experiências. 
Aos funcionários da Secretaria da Pós-graduação da FOB-USP, Giane, Aurélio, Ana Letícia e Solange, pela atenção e disponibilidade sempre.

A todos os funcionários da Biblioteca da FOB-USP, particularmente, Rita de Cássia, Ademir, Ana Paula, Jane e César, pela atenção e profissionalismo.

A todos os funcionários da reprografia, em especial, Lígia, Vanessa e Salvador, o meu muito obrigado. 


\section{AGRADECIMENTOS INSTITUCIONAIS}

À Faculdade de Odontologia de Bauru, Universidade de São Paulo.

À Direção da Faculdade de Odontologia de Bauru, Universidade de São Paulo, na pessoa da Diretora Professora Dra. Maria Fidela de Lima Navarro.

À Comissão de Pós-Graduação da Faculdade de Odontologia de Bauru, Universidade de São Paulo, na pessoa de seu presidente Professor Dr. José Carlos Pereira.

À Biblioteca da Faculdade de Odontologia de Bauru, Universidade de São Paulo.

Ao Departamento de Morfologia, Estomatologia e Fisiologia da Faculdade de Odontologia de Ribeirão Preto, Universidade de São Paulo, na pessoa do Professor Doutor Paulo Tambasco de Oliveira, pelo desprendimento e atenção, também pela confiança em nós depositada.

Ao Departamento de Biologia Celular do Instituto de Biologia da Universidade de Campinas - UNICAMP, na pessoa do Professor Doutor Benedicto de Campos Vidal, pelo exemplo de dedicação à Ciência.

À CAPES pelo auxílio pecuniário. 


\section{A DEUS eu agradeço o precioso dom da vida...}

os meus ouvidos para que eu possa compartilhar a arte da música...

os meus olhos para que eu possa assistir ao nascer e ao pôr do sol...

e a minha sensibilidade para perceber essas maravilhas que estão ao meu alcance todos os dias! 


\section{SUMÁRIO}

RESUMO $\quad$ xvi

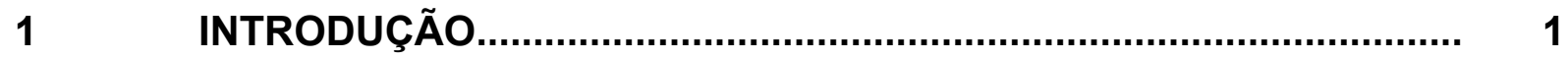

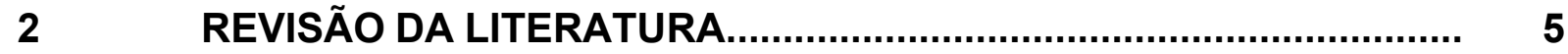

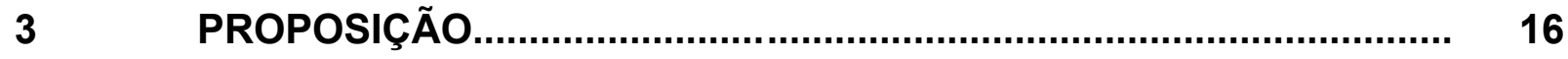

$4 \quad$ MATERIAL E MÉTODOS .............................................................. 18

$4.1 \quad$ Obtenção e seleção da amostragem................................................. 19

$4.2 \quad$ Critérios de inclusão da amostra...................................................... 20

$4.3 \quad$ Caracterização da amostra............................................................... 20

$4.4 \quad$ Aspectos histotécnicos................................................................ 22

4.4.1 Microtomia.................................................................................. 22

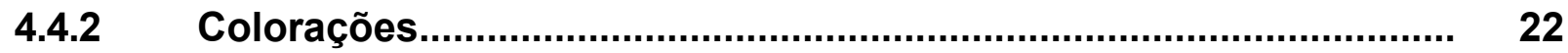

4.4.2.1 Hematoxilina-eosina de Harris (H.E.)......................................... 22

4.4.2.2 Brown e Brenn (B.B.)............................................................. 22

4.4.2.2.1 Soluções utilizadas.................................................................... 22

4.4.2.2.2 Protocolo utilizado......................................................................... 24

4.4.2.3 Lâminas para observação sob microscopia de polarização........... 25

$4.5 \quad$ Análise microscópica descritiva..................................................... 25

$4.6 \quad$ Análise estatística................................................................ 30

$5 \quad$ RESULTADOS..................................................................... 31

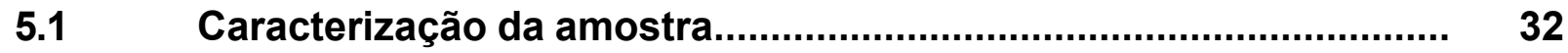

$5.2 \quad$ Análise microscópica............................................................... 35

5.2.1 Ao microscópio de luz comum................................................ 35

5.2.2 Ao microscópio de luz polarizada............................................... 54

Análise estatística................................................................ 70

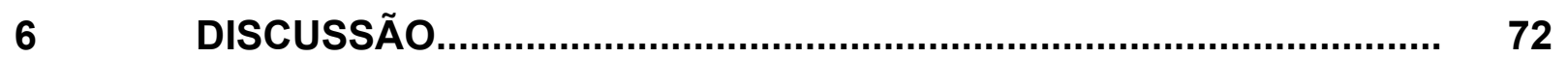

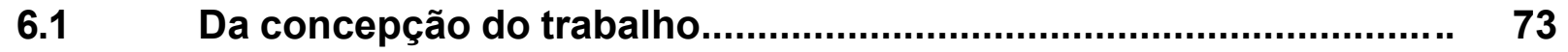

6.2 Da metodologia empregada.............................................................. 74

6.3 Dos resultados obtidos............................................................... 77

6.4 Das implicações clínicas........................................................... 86

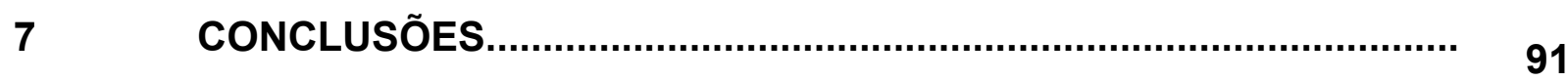

REFERÊNCIAS BIBLIOGRÁFICAS........................................................ 93

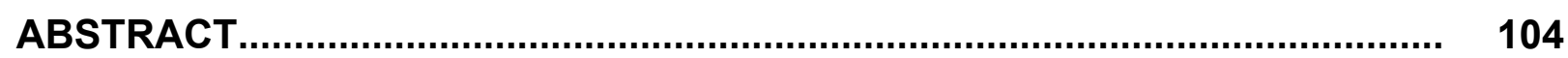

APÊNDICES..................................................................................... 106 


\section{RESUMO}

Propôs-se analisar os sialólitos pelas microscopias óptica comum e de luz polarizada. Utilizaram-se 15 casos, cujos blocos, lâminas e fichas de envio das peças cirúrgicas eram provenientes dos arquivos do Laboratório de Anatomia Patológica do Departamento de Estomatologia, disciplina de Patologia da Faculdade de Odontologia de Bauru, Universidade de São Paulo. À microscopia óptica comum os espécimes foram analisados por meio das colorações hematoxilina-eosina de Harris e de Brown e Brenn. Observou-se que os sialólitos não têm estrutura uniforme, variando sua morfologia não apenas no mesmo espécime como também de um espécime para outro. O padrão lamelar de organização foi predominante tanto ao microscópio óptico comum como ao microscópio de luz polarizada. Houve a evidenciação de bactérias em todos os espécimes. Por meio da luz polarizada estabeleceu-se uma classificação para os padrões encontrados: linear, puntiforme, mosaico, radiado, homogêneo e misto. Nos espécimes que apresentavam tecido mole (26,6\% da amostra) detectou-se a presença de mineralizações estromais puntiformes à luz polarizada. 
1 INTRODUÇÃO 


\section{INTRODUÇÃO}

Sialadenite é a inflamação que ocorre nas glândulas salivares, podendo ser sua origem de causas variadas infecciosas ou não $37,42,53,81,93,105$. A maioria das infecções bacterianas, causadoras da sialadenite, origina-se de uma obstrução ou diminuição do fluxo salivar, permitindo assim a disseminação retrógrada de bactérias através do sistema ductal $22,56,80,86,105$. O bloqueio do ducto pode ser causado por sialolitíase, constrições congênitas ou por compressão de um tumor adjacente ${ }^{35,80,93}$.

Sialolitíase é o termo utilizado para descrever a formação de cálculos e conseqüente bloqueio do fluxo salivar, no ducto excretor de saliva ou no próprio corpo da glândula ${ }^{16,35,92,106}$; esses cálculos, denominados sialólitos, são formados por uma porção orgânica e uma porção inorgânica, variando em tamanho desde microscópicos a cinco ou seis centímetros em seu maior eixo ${ }^{11,16,21,36,38,47,59,92,110,124}$. Geralmente são esféricos ou ovais quando formados no interior da glândula e alongados se formados intraductalmente ${ }^{10,16}$.

A causa dos sialólitos é desconhecida ${ }^{54,80,92}$, seu desenvolvimento não está relacionado a qualquer desordem sistêmica no metabolismo de cálcio e fósforo ${ }^{58,80,89}$.

Sendo mais comum sua presença nas glândulas submandibulares, os sialólitos podem ocorrer nas parótidas, sublinguais, bem como nas glândulas salivares acessórias de lábios, mucosa jugal, língua e palato ${ }^{5,43,44,51,58,66,81,84,89,95,125}$. Acredita-se que sua maior ocorrência nas glândulas submandibulares seja devido à viscosidade aumentada de sua saliva, bem como ao curso de seu ducto principal ser ascendente, longo e irregular ${ }^{43,66,125,127}$. 
Os sialólitos podem ser únicos ou múltiplos, localizando-se em qualquer ponto do trajeto do ducto ou dentro da própria glândula ${ }^{80,106}$. Os cálculos pequenos, às vezes, se localizados na parte mais periférica do ducto, podem ser removidos pela massagem local até sua expulsão ${ }^{106}$; os maiores quase sempre exigem remoção cirúrgica; se estiverem próximos ou na intimidade da glândula, particularmente quando múltiplos, poderá ser necessária até a extirpação da glândula $66,106,125$.

As tomadas radiográficas oclusais são as mais apropriadas para a visualização de sialólitos localizados na porção terminal do ducto submandibular; nas radiografias panorâmicas ou periapicais o cálculo pode aparecer superposto à mandíbula podendo ser confundido com uma lesão intra-óssea. Múltiplos cálculos na parótida podem mimetizar, radiograficamente, linfonodos parotídeos calcificados, como pode ocorrer na tuberculose ${ }^{52,80,105}$.

Nem todos os cálculos salivares podem ser detectados em radiografias convencionais devido ao grau de mineralização diminuído, nesses casos é indicada a realização de uma sialografia ${ }^{37,52}$, ou seja, a injeção retrógrada de um material radiopaco no sistema de ductos da glândula salivar e o estudo de sua distribuição por meio de uma radiografia, a sialografia é contra-indicada em sialadenite aguda ${ }^{106}$. A cintilografia ${ }^{102}$, também tem sido utilizada como substituição da sialografia ${ }^{48}$. Outras técnicas mais avançadas como ultrassonografia ${ }^{37,82,102}$, sialoendoscopia ${ }^{74,78,126}$, litotripsia ${ }^{50}$, tomografia computadorizada, imagem por ressonância magnética ${ }^{92}$ ou sialolitectomia com Laser de $\mathrm{CO}_{2}{ }^{8}$, associadas ${ }^{79,82,102}$ ou não, têm sido cada vez mais utilizadas, algumas apenas para diagnóstico, outras como tratamento. Uma técnica não muito atual, porém, citada e utilizada em 
diagnóstico diferencial para carcinoma mucoepidermóide de alto grau é a citologia por aspiração com agulha fina ${ }^{37,113}$.

Cortes desmineralizados dessas estruturas nos mostram padrões semelhantes aos padrões encontrados em cálculos de outros sistemas excretórios (rins, bexiga e vesícula biliar): um núcleo de substância orgânica é rodeado por lamelas de material mineralizado dispostas em camadas concêntricas, às vezes observando-se padrão homogêneo ${ }^{1,2,54,92,106,114}$. Sua composição é semelhante à composição dos cálculos dentários ${ }^{70,77}$. Bactérias são vistas apenas na superfície externa dos sialólitos ${ }^{1,2,3,5,54,70,77}$. Se o ducto associado também for analisado, freqüentemente mostrará metaplasia de células escamosas, oncocíticas ou mucosas. Também é evidente uma inflamação periductal ${ }^{1,5,58,80}$.

Pelo exposto alguns questionamentos ainda pairam sobre os sialólitos e que talvez possam influenciar no comportamento de seus tecidos circunvizinhos como, por exemplo, sua morfologia e presença de bactérias em superfície, daí o motivo deste estudo. 
2 REVISÃO DA LITERATURA 


\section{REVISÃO DA LITERATURA}

Neste capítulo buscourse analisar trabalhos realizados sobre o assunto, resgatados dos bancos de dados disponíveis, referentes ao período de 1839 a 2002, a partir de palavras-chave como sialólito, cálculo do ducto salivar, litíase salivar, sialolitíase e cálculo salivar. Os trabalhos fora deste período foram resgatados de referências obtidas dos arquivos preexistentes de separatas ou por constarem nos trabalhos resgatados. O capítulo será organizado por assuntos.

Dá-se o nome de cálculos ${ }^{20}$ (latim calculus = pedra de contar) ou litíase ${ }^{68}$ (grego lithos = pedra) às massas esferoidais, ovóides ou facetadas, sólidas, concretas e compactas, de consistência argilosa a pétrea, que se formam no interior de órgãos ocos, cavidades naturais do organismo, condutos naturais, no interior de vasos ou no próprio corpo da glândula; um núcleo de substância orgânica é rodeado por lamelas de material mineralizado, dispostas em camadas. Como regra geral de nomenclatura, utiliza-se um termo designativo do local de formação ou origem, acrescido do sufixo litíase para denominar a ocorrência do fenômeno e do sufixo lito para denominar o cálculo. Sialolitíase é o termo utilizado para descrever o fenômeno de formação de cálculos no sistema ductal da glândula salivar, o cálculo é o sialólito ${ }^{16,92,108,109}$.

Designados como "cálculos especiais", foram primeiramente descritos por SCHERER ${ }^{101}$ em 1737, referindo-se aos sialólitos das glândulas salivares maiores.

Em alguns relatos também foi encontrado o termo ptiálito ${ }^{83,88}$, derivado do grego ptial, que significa saliva, referindo-se a sialólito. 
A maioria dos sialólitos é encontrada em adultos $^{22,46,63,66,67,69,72,81,86,89,99,125}$, com discreta predileção pelo gênero masculino ${ }^{43,107,118}$. Podem ocorrer múltiplas lesões ${ }^{23,65}$, porém o envolvimento bilateral é raro. Em alguns casos são assintomáticos e apenas descobertos em exames de rotina ${ }^{22}$.

O cálculo salivar pode causar tumefação da glândula salivar afetada, às vezes, aumentado durante o ato da mastigação, acompanhado de dor transitória. A obstrução ductal pelo sialólito causa diminuição ou estagnação do fluxo salivar, permitindo a disseminação retrógrada de bactérias através do sistema ductal. Essas infecções são manifestadas pela drenagem de pus por meio dos ductos excretores $^{22,42,53,66,80}$. Quando a ocorrência é em glândulas salivares acessórias, pode assemelhar-se, clinicamente, a mucocele ${ }^{5,72}$, tornando-se essencial a biópsia da lesão ${ }^{5}$.

Os cálculos salivares podem apresentar tamanho que varia entre microscópicos a cinco ou seis centímetros em seu maior eixo ${ }^{11,21,36,38,47,59,110,118,124}$. A observância da variação na morfologia, bem como no grau de mineralização dos sialólitos, particularmente em suas áreas periféricas, são também de grande valia clínica, visto nem sempre a imagem radiográfica corresponder ao tamanho real do cálculo salivar².

As glândulas salivares submandibulares e seu sistema ductal são os mais freqüentemente acometidos pela presença de sialólitos, representando $85 \%$ a $95 \%$ dos casos; de $5 \%$ a $10 \%$ dos casos ocorrem nas parótidas e menos de $5 \%$ nas glândulas sublinguais ${ }^{42,43,66,81,118,125}$. As glândulas salivares acessórias são também acometidas $5,44,58,72,82,84,89,95$. A composição e morfologia dos sialólitos tanto em glândulas salivares maiores quanto em menores é igual| $5,16,22,40,44,58,72,77,89,95,117$. 
A patogenia dos sialólitos tem sido amplamente discutida e muitas sugestões de núcleos iniciais, ao redor dos quais o cálculo salivar pudesse desenvolver-se, têm sido apresentadas: fungos $^{60}$, bactérias $^{1,49,77,96}$, corpos estranhos $^{73,85,87,98,125}$ e células epiteliais descamadas ${ }^{1,16,39}$. A hipersecreção de

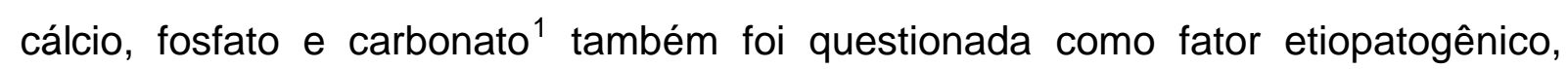
entretanto sabe-se que nenhuma doença ou alteração sistêmica tem correlação com a formação de sialólitos ${ }^{58,89}$.

Segundo TAKAHASHI et al. ${ }^{114}$, quatro teorias destacam-se a fim de explicar a patogenia dos sialólitos: teoria bacteriana ${ }^{25,96}$ : primeiramente ocorre a infecção bacteriana retrógrada no ducto excretor da glândula. O núcleo formado por bactérias, células epiteliais descamadas, produtos da decomposição bacteriana e leucócitos gradativamente recebe aposição de sais de cálcio, formando o cálculo salivar $^{112}$; teoria da inflamação: a composição e as propriedades da saliva são alteradas como resultado de inflamação na glândula salivar ou ducto. Ocorre degeneração do epitélio glandular e os sais de cálcio, contidos na saliva estagnada, depositam-se ao redor do epitélio ductal descamado ou de leucócitos ${ }^{25,61}$; teoria do corpo estranho ${ }^{25}$ : qualquer corpo estranho como osso de peixe, cabelo, cerda da escova dental, espinho, palha de trigo ou uma pequena pena, acidentalmente podem penetrar no ducto excretor salivar, funcionando como um núcleo de deposição de sais minerais $25,73,85,87,98,125$; teoria do trauma local ${ }^{25}$ : alguns autores sugerem que as intervenções cirúrgicas na região da glândula submandibular poderiam induzir a formação de sialólitos ${ }^{25,34}$; outros admitem que simples contusões locais poderiam desencadear o processo de formação dos cálculos saliva res ${ }^{7}$. 
HARRILL et al. ${ }^{40}$, em 1959, sugeriram a formação de um gel mucóide, ao redor do qual os sais minerais iriam agregando-se, semelhantemente aos urólitos, estes com maior tendência à laminação concêntrica que os sialólitos.

ANNEROTH et al. ${ }^{1}$, em 1978, propuseram que a formação do cálculo é baseada em um núcleo formado pela degeneração coloidoquímica das proteínas e da mucina salivares e sua gradual mineralização. O gel formado é transformado em núcleo cristalino, inorgânico, como resultado da deposição de sais minerais. Quando o núcleo está formado, hidroxiapatita deposita-se ao redor, ritmicamente, resultando um crescimento gradual e um padrão lamelar. Essa teoria parece explicar a grande freqüência de sialólitos nas glândulas submandibulares em comparação com as parótidas: o pré-requisito para a formação do "gel mucóide" e sua mineralização é mais favorável no sistema de ductos da glândula submandibular que é longo, irregular e ascendente em seu curso, facilitando a estagnação da saliva ${ }^{43,83,118}$.

Considerando todas essas teorias, alguns autores concluíram que os sialólitos são causados pela combinação de fatores predisponentes locais, mecânicos e bioquímicos ${ }^{25,43,56,114}$.

O papel dos fosfolipídios como mecanismo inicial da mineralização também toma lugar nas discussões ${ }^{111}$. BOSKEY et al. ${ }^{14}$, em 1981, propuseram que os fosfatos fosfolipídicos complexos e proteolipídios estivessem envolvidos em mineralizações biológicas. Sabe-se que a saliva contém pequena quantidade de lipídios $^{111}$, enquanto a concentração destes é alta em cálculo salivar, ${ }^{4,14,15,30,71,111}$. Observou-se nos resultados de ENNEVER; VOGEL; BENSON ${ }^{30}$, que a fonte de lipídios necessária para a mineralização, advinha dos componentes de membrana derivados das bactérias observadas na camada mais externa dos sialólitos. 
EPIVATIANOS et al. ${ }^{31}$, em 1986, observaram pequenas mineralizações intracelulares em células de glândulas salivares de gatos bem como no interior de macrófagos situados entre as células acinares. Microanálises nessas mineralizações revelaram a presença de cálcio e fósforo nos cristais. Os autores sugeriram a presença destes microcálculos como fator significante a ser considerado na etiologia de sialólitos em humanos ${ }^{115}$, existe semelhança na morfologia entre os cristais encontrados no interior de células acinares de glândulas salivares de gatos e os encontrados em humanos ${ }^{31,42,122}$.

Microcálculos, ou micrólitos, são encontrados tanto em glândulas salivares normais quanto em sialadenites ${ }^{31,32,42,122}$.

Ao microscópio eletrônico, a superfície dos salólitos é irregular, nodosa ou granular. $\mathrm{Na}$ camada mais externa, observam-se estruturas globulares uniformemente organizadas, conferindo aspecto regular à superfície ${ }^{10,114}$. Estes glóbulos também são observados na camada imediatamente inferior à externa, demonstrando pequenas proeminências, sugerindo que o crescimento do sialólito se faz a expensas da fusão dessas estruturas, como múltiplos centros de mineralização ${ }^{70,114}$

Nas superfícies de corte, observa-se substância homogênea central, desestruturada, como um núcleo, rodeada de camadas relativamente concêntricas, de várias espessuras, alternadamente claras e escuras ${ }^{1,10,40,43,100,117}$; em grande aumento, as linhas claras indicam porções bem mineralizadas e as escuras, porções pouco mineralizadas. Esta arquitetura lamelar, também identificada em cortes ao microscópio óptico ${ }^{1,51,114}$, representa a expressão morfológica de deposição rítmica de material, podendo ser comparada ao Fenômeno de Liesegang ${ }^{54,125}$. A periferia 
dos sialólitos mostra-se como zona condensada com alta densidade eletrônica, mostrando uma matriz granular ou fibrosa ${ }^{114}$.

Bactérias foram vistas, em variados graus de mineralização, na periferia de cálculos salivares enquanto nas porções centrais não foram observadas estruturas bacterianas ${ }^{1,2,3,5,54,70,77}$.

Pesquisas in vitro com microorganismos isolados da placa bacteriana dental, têm demonstrado dois padrões de mineralização: intra e extracelular ${ }^{29}$, identificados por difração de raios x como sendo hidroxiapatita. SCHROEDER ${ }^{104}$, em 1969, demonstrou em cálculo dentário dois tipos de mineralização, denominando-as de tipo a e tipo b. A mineralização do tipo "a", era formada apenas na presença ou associação com microorganismos, enquanto que a do tipo "b", aparentemente não estava diretamente relacionada aos microorganismos.

Os microorganismos em degeneração, mineralizados ou não, são morfologicamente idênticos às estruturas chamadas de "glóbulos" por HÖHLING et al. ${ }^{45}$, em 1968. O padrão de mineralização dos microorganismos em cálculo salivar é muito semelhante ao padrão observado no cálculo dentário ${ }^{28,70,77,97}$.

Na parte central dos sialólitos, observam-se corpos esferóides com baixa densidade eletrônica, algumas vezes, apresentando pequenos cristais em sua superfície. Esses corpos esferóides aparecem tanto nas áreas bem mineralizadas quanto nas pouco mineralizadas, onde o conteúdo de matriz orgânica é maior. Ao microscópio eletrônico observa-se a presença de pequenos cristais em forma de agulha na superfície destes corpos, o que nas áreas mais mineralizadas acentua-se, cobrindo praticamente toda a superfície das estruturas, como se estivessem englobando-as. Esta morfologia e tamanho de cristais coincidem com os cristais de

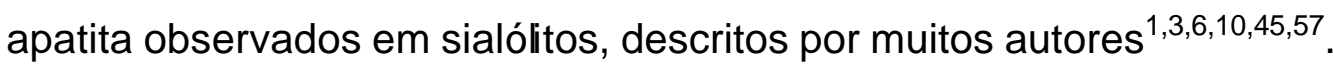


Os componentes inorgânicos são em grande parte cristalinos e principalmente compostos por fosfato de cálcio $(70 \%)$ na forma de apatita $^{2,3,10,19,40,57,66,70,76,98,114}$, carbonato de cálcio (10\%) e ainda pequenas quantidades de outros componentes estão presentes $3,57,70,114$. A composição inclui: cálcio, fósforo, oxigênio e pequenas quantidades de hidrogênio, magnésio, zinco, ferro, cobre e manganês ${ }^{27,40,43,76}$, sódio, alumínio, silício, enxofre, cloro, potássio ${ }^{43,76}$, e ainda, cromo $^{43}$. O termo apatita refere-se a um grupo de compostos fosfatocomplexos que ocorre biologicamente, onde são análogos quimicamente e possuem estrutura espacial semelhante ${ }^{10}$.

Tanto nas porções centrais como na periferia do cálculo salivar podemos observar a presença de apatita ${ }^{6,100}$. Em alguns casos pode ser observado whitlockite $6,19,76,100,114$ ou âTCP (beta tricálcio fosfato), o que em 1958, BLATT et al. ${ }^{10}$, consideraram como sendo um artefato térmico derivado dos procedimentos para obtenção da difração de raios x. JENSEN; DANO ${ }^{57}$, em 1952, também encontraram de dois a quatro por cento de calcita cristalina em cálculo salivar. Ácido úrico foi descrito em sialólito de glândula parótida em um caso de paciente apresentando gota $^{10}$. SAKAE; YAMAMOTO; HIRAI ${ }^{100}$, em 1981, mapearam a superfície de uma seção de sialólito, mostrando a distribuição simultânea de três minerais, todos fosfatos de cálcio: brucita (hidróxido de magnésio trigonal), whitlockite e apatita; sugerindo que a deposição de brucita seria nos estádios prematuros da formação do sialólito, transformando-se, então, em whitlockite e ou apatita.

Sabe-se que, quimicamente, hidroxiapatita e whitlockite dificilmente ocorrem em estado puro nos tecidos biológicos e sim combinados com vários íons $^{57,75,103}$. A whitlockite ocorre apenas em mineralizações patológicas como nos sialólitos e urólitos ${ }^{6,98}$, nota-se também a presença deste mineral na cárie. 0 
processo de deposição mineral na maioria dos processos patológicos é similar ao de mineralização orgânica normal ${ }^{14,98}$.

Em 1968 HOLING; SCHOPFER ${ }^{45}$ observaram a distância entre os centros de mineralização em tíbia de frango e sialólito, sugerindo semelhança entre o padrão de mineralização em tecidos de origem colágena e não colágena.

Para estudar a distribuição dos componentes minerais em sialólitos, alguns autores ${ }^{2,43,100}$ utilizaram a técnica microrradiográfica encontrando grande variação de padrões de absorção. Concluíram que por meio desta técnica é impossível distinguir os diferentes minerais que possuem semelhantes características de absorção dos feixes.

A análise por difração de raios $x$ mostrou que a porção central dos sialólitos apresenta-se radiolucente, sem microdifração, envolta pela periferia radiopaca, não uniformemente organizada, ora apresentando-se lamelar, ora em "favo de mel" ou, ainda, aleatoriamente disposta $2,6,19,33,76,95,100$. Em alguns casos existe mais de um centro radiolucente ${ }^{2,6,95}$. Os padrões da apatita e da whitlockite foram bem evidenciados ${ }^{2,19,76,100}$. Outra técnica para a aplicação da microdifração de raios x é a difração de pulverização que, utilizada em sialólitos ${ }^{10,40,76,95}$, confirmou a presença dos dois componentes minerais principais: apatita e, em menor quantidade, whitlockite $2,10,57$.

Por meio da energia dispersiva de raios $\mathrm{x}$, espectroscopia, foram demonstradas $^{76,95,122}$ as proporções dos diversos elementos constituintes dos sialólitos.

A matriz orgânica dos cálculos salivares é constituída de diferentes proteínas e carboidratos ${ }^{10,40}$, também possuindo pequenas quantidades de lipídios, incluindo ácidos graxos, colesterol, triglicérides e fosfolipídios ${ }^{4,14,15,111}$. Estudos 
qualitativo e quantitativo para presença de lipídios em matriz orgânica de sialólito, foram realizados em 1982 por SLOMIANY et al. ${ }^{111}$, detectando 57\% de lipídios com pH neutro, 40\% de glicolipídios e 3\% de fosfolipídios. A coloração de OTAN, ósmio tetróxido-alfa-naftilamina, foi utilizada por ANNEROTH et al. ${ }^{4}$, em 1977, para a demonstração da presença de duas classes principais de fosfolipídios: hidrofóbicos e hidrofílicos; os fosfolipídios hidrofóbicos coram-se em negro enquanto os hidrofílicos são corados em vermelho-alaranjado. Por meio desta pesquisa detectou-se como principal fosfolipídio hidrofílico o fosfofingosídio, enquanto como principal fosfolipídio hidrofóbico o colesterol.

Os carboidratos encontrados na matriz orgânica de sialólitos foram: galactose, glucose, mannose, rhamnose e fucose, também presentes em matrizes advindas de urólitos $^{40,98}$.

Na coloração de hematoxilina-eosina de Harris (H.E.), a matriz orgânica cora-se pouco com hematoxilina enquanto que com azul de toluidina aquosa observa-se coloração azul uniforme, com pequenas áreas em vermelho purpúreo $3,5,40,58$.

Os cristais são átomos arranjados de forma a exibir padrão tridimensional $^{10}$ e em tecidos mineralizados são geralmente alongados e algumas vezes similarmente orientados, o que pouco ocorre nos cálculos salivares onde o padrão dominante de orientação dos cristais é aleatório ${ }^{2}$. Os cristais observados em sialólitos são tão pequenos quanto aqueles encontrados em outras mineralizações biológicas, indicando que as condições para precipitação de apatita são desfavoráveis, devido, em parte, à relativa alta concentração de íons carbonato.

Os cristais nos sialólitos também foram analisados sob luz polarizada: alguns autores não evidenciaram birrefringência nos espécimes examinados ${ }^{10,115}$. 
TRAINI et al. ${ }^{121}$ observando a presença de estruturas cristalinas discutiram a gênese de um sialólito. Em análise de 56 casos de cálculo salivar, LAFORGIA et al. ${ }^{63}$ destacaram a distribuição topográfica das áreas que continham substância mineralizada, detectando a ausência desta substância nas áreas centrais dos sialólitos. 
3 PROPOSIÇÃO 


\section{PROPOSIÇÃO}

Com base na literatura pertinente e a partir de lâminas e blocos obtidos dos arquivos do Laboratório de Anatomia Patológica do Departamento de Estomatologia, disciplina de Patologia da Faculdade de Odontologia de Bauru, Universidade de São Paulo, propusemo-nos a:

3.1 Caracterizar os aspectos morfológicos dos sialólitos, sob microscopia óptica comum;

3.2 Estudar os aspectos particulares de suas estruturas, sob microscopia de luz polarizada;

3.3 Evidenciar a presença de bactérias nos sialólitos. 


\section{MATERIAL E MÉTODOS}

\subsection{OBTENÇÃO E SELEÇÃO DA AMOSTRAGEM:}

A amostra foi constituída de cortes microscópicos montados em lâminas e peças cirúrgicas incluídas em blocos de parafina pertencentes aos arquivos do Laboratório de Anatomia Patológica do Departamento de Estomatologia, disciplina de Patologia da Faculdade de Odontologia de Bauru, Universidade de São Paulo. Os espécimes, perfazendo um total de 15 casos de sialólitos, são provenientes das diferentes clínicas da Faculdade de Odontologia de Bauru, de outros centros de ensino e de consultórios particulares.

A seleção da amostragem obedeceu à ordem cronológica de entrada nos registros da disciplina de Patologia desde 1963 até 2002. Foram resgatados todos os casos de Sialólito cadastrados, a partir de seus respectivos laudos anatomopatológicos, descrevendo inclusive as características registradas na clínica e na análise microscópica óptica.

Os cortes observados com coloração hematoxilina-eosina de Harris (H.E.) deveriam estar preservados e não apresentar artefatos de técnica, favorecendo uma análise morfológica criteriosa. Em alguns casos foi necessária a confecção de novos cortes para esta coloração.

Para coloração Brown e Brenn (B.B.) foi necessária a confecção de novos cortes para todos os espécimes, bem como para análise pela microscopia de polarização, neste caso, sem coloração ${ }^{123}$. 


\subsection{CRITÉRIOS DE INCLUSÃO DA AMOSTRA:}

Foram adotados os seguintes critérios:

- Laudos com diagnóstico microscópico sugestivo, compatível ou conclusivo de Sialólito, podendo estar associado à outra lesão;

- Laudos com diagnóstico microscópico sugestivo, compatível ou conclusivo de Cálculo salivar, podendo estar associado à outra lesão;

- Casos em que seus respectivos blocos possibilitassem a confecção de novos cortes.

\subsection{CARACTERIZAÇÃO DA AMOSTRA:}

A amostra foi caracterizada de acordo com a distribuição nos seguintes parâmetros: gênero, idade, localização da lesão, sintomatologia, tumefação, tempo de evolução, fatores etiológicos associados como trauma local ou inflamação recorrente e relatos radiográficos. Os dados obtidos foram organizados em tabela específica como no exemplo a seguir e expostos no capítulo de resultados. 
Tabela 1 - Modelo de tabela idealizado para registro dos dados gerais resgatados de resumos clínicos contidos nas requisições de solicitação de exame anatomopatológico

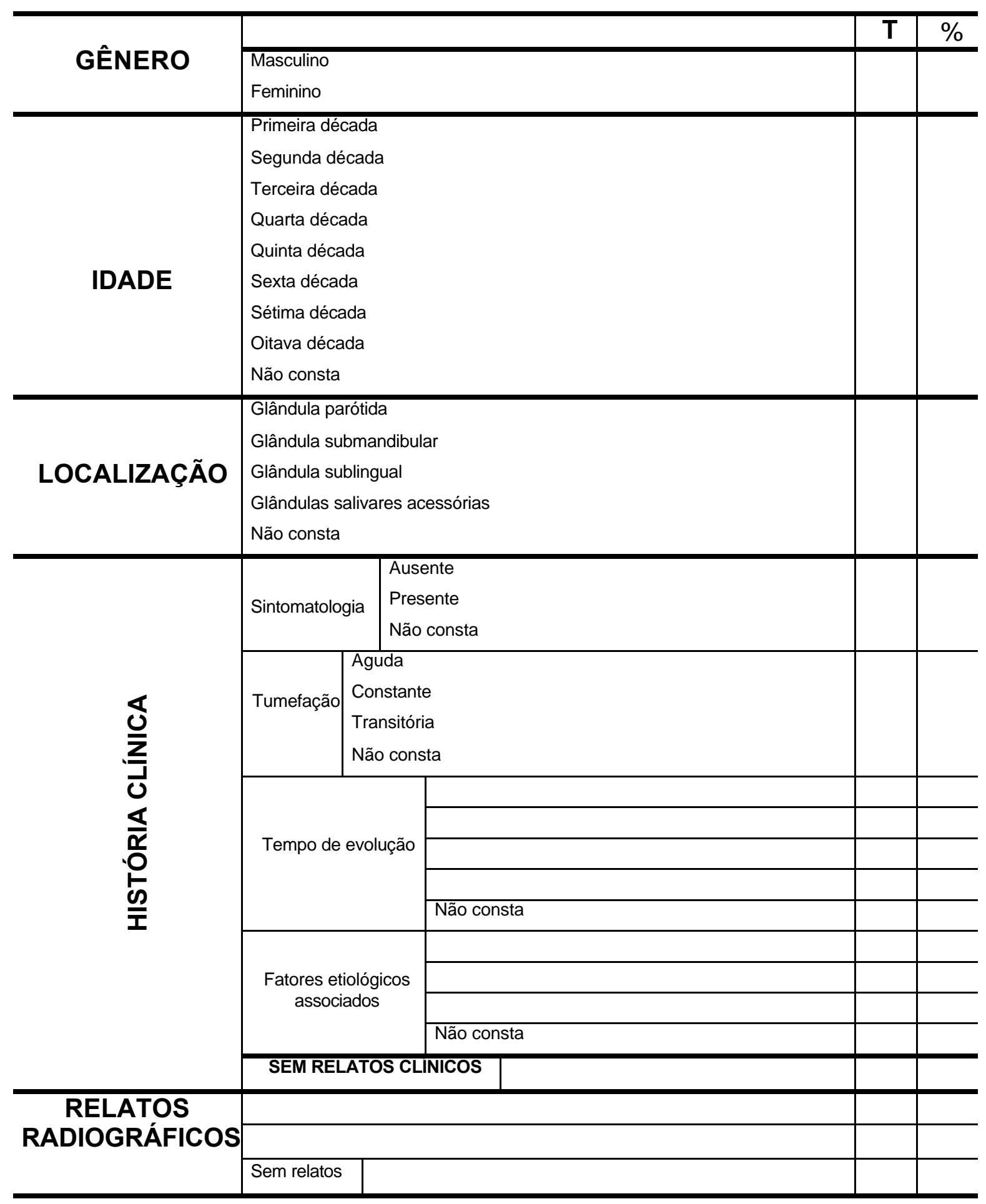




\subsection{ASPECTOS HISTOTÉCNICOS:}

\subsubsection{Microtomia:}

Cortes de $5 \mu \mathrm{m}$ de espessura foram obtidos utilizando-se um micrótomo Leica RM-2165. A partir da superfície de corte preexistente nos blocos, foram realizados cortes seriados, até a obtenção de duas lâminas para cada espécime sendo uma para coloração Brown e Brenn (B.B.) e outra para observação em microscópio de polarização. Em alguns casos foi feita uma terceira lâmina para coloração em hematoxilina-eosina de Harris (H.E.), pois a lâmina do arquivo não favorecia uma análise morfológica criteriosa.

\subsubsection{Colorações:}

\subsubsection{Hematoxilina-eosina de Harris (H.E.):}

O protocolo utilizado foi o mesmo dos procedimentos de rotina do Laboratório de Anatomia Patológica do Departamento de Estomatologia, disciplina de Patologia da Faculdade de Odontologia de Bauru, Universidade de São Paulo.

\subsubsection{Brown e Brenn (B.B.):}

4.4.2.2.1 Soluções utilizadas:

a) Hematoxilina de Harris

Hematoxilina, 1g;

Álcool absoluto, 10ml;

Alúmen de potássio, $20 \mathrm{~g}$;

Água destilada, 200ml;

- $\quad$ Óxido de mercúrio amarelo, 0,5g. 
b) lodo de Gram 1\% (Lugol)

- lodo, 1g;

- $\quad$ lodeto de potássio, 2g;

- Água destilada, 300ml.

c) Éter-Acetona

- Éter, 80ml;

- Acetona, 120ml.

d) Ácido pícrico + Acetona

- $\quad$ Ácido pícrico, 0,1g;

- Acetona, 100ml.

e) Solução de Galego

- Formaldeído, 1ml;

- Ácido acético glacial, 0,5ml;

- Água destilada, 50ml.

f) Fucsina Básica (estoque)

- Fucsina, 0,25g;

- Água destilada, 100ml.

g) Solução de trabalho

- Solução de estoque, $1 \mathrm{ml}$;

- Água destilada, 10ml;

- Solução em repouso por 24 horas;

- Filtrar antes do uso. 
h) Cristal violeta a $1 \%$

- Cristal violeta, 1g;

- Álcool etílico, 10ml;

- Ácido carbólico, 2g;

- Água destilada, 100ml;

- Solução em repouso por 24 horas;

- Filtrar antes do uso.

4.4.2.2.2 Protocolo utilizado:

a) Desparafinizar e hidratar;

b) Corar com hematoxilina de Harris por cinco minutos;

c) Passar no diferenciador por um minuto;

d) Lavar em água corrente por cinco minutos;

e) Secar as bordas da lâmina com papel filtro, evitando ressecar o corte;

f) Corar com cristal violeta por dois minutos;

g) Escorrer o excesso de corante e cobrir os cortes com lugol por um minuto;

h) Escorrer o excesso da solução, diferenciar os cortes em éter + acetona até não ter mais corante;

i) Lavar as lâminas rapidamente em água destilada e secar com papel filtro, sem ressecar os cortes;

j) Corar com solução de trabalho fucsina por três minutos;

k) Escorrer o excesso do corante, lavar rapidamente com água destilada, secar as lâminas sem ressecar os cortes;

I) Diferenciar na solução de Galego por três minutos;

m) Lavar as lâminas em água destilada e secá-las sem ressecar os cortes; 
n) Mergulhar em seguida em acetona por dez segundos a um minuto;

o) Diferenciar em ácido pícrico + acetona até que o tecido tome coloração róseaamarelada por dez segundos;

p) Imergir três vezes em acetona pura sob leve agitação para remover completamente o ácido pícrico;

q) Lavar em mistura de partes iguais acetona + xilol por 15 segundos;

r) Clarear em xilol, dez banhos;

s) Montar com resina permont.

\subsubsection{Lâminas para observação sob microscopia de polarização:}

Estas lâminas não foram coradas. Após a desparafinização foram montadas com lamínula e resina permont.

\subsection{ANÁLISE MICROSCÓPICA DESCRITIVA:}

Ao microscópio óptico comum as lâminas foram analisadas do menor ao maior aumento, seqüencialmente. Cada caso foi analisado inicialmente em hematoxilina-eosina de Harris (H.E.) e, na seqüência, em coloração Brown e Brenn (B.B.). A análise foi feita de forma descritiva e os dados coletados foram demonstrados em tabelas elaboradas previamente, como os exemplos apresentados a seguir: 
Tabela 2 - Modelo de tabela idealizado para registro dos achados microscópicos referentes aos cortes corados em hematoxilina-eosina de Harris (H.E.)

\begin{tabular}{|c|c|c|c|c|c|c|c|c|c|c|c|c|c|c|c|c|c|c|c|c|c|}
\hline \multicolumn{22}{|c|}{\begin{tabular}{rl|l|l|l|l|l|l|l|l|l|l|l|l|l|l|l|l|l|} 
ESPECIME & 14 & 2 & 3 & 4 & 5 & 6 & 7 & 8 & 9 & 10 & 11 & 12 & 13 & 14 & 15 & $\mathrm{~T}$ & $\%$ \\
\end{tabular}} \\
\hline \multicolumn{22}{|c|}{\begin{tabular}{l|l|l|}
$\circ$ & $=$ & Um só centro de mineralização
\end{tabular}} \\
\hline \multirow{16}{*}{$\frac{0}{\underline{E}}$} & \multirow{4}{*}{ 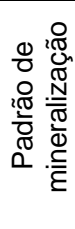 } & \multirow{2}{*}{ 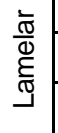 } & \multicolumn{5}{|c|}{ Mais de um centro de mineralização } & & & & & & & & & & & & & & \\
\hline & & & & & & & & & & & & & & & & & \\
\hline & & \multicolumn{6}{|c|}{ Homogêneo } & & & & & & & & & & & & & & \\
\hline & & \multicolumn{6}{|c|}{ Misto } & & & & & & & & & & & & & & \\
\hline & \multirow{8}{*}{ 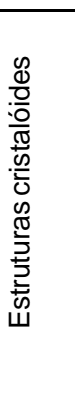 } & \multirow{7}{*}{ 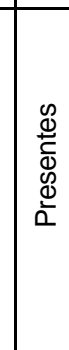 } & \multirow{2}{*}{\multicolumn{2}{|c|}{ Freqüência }} & Escas & SSOS & & & & & & & & & & & & & & & \\
\hline & & & & & \multicolumn{3}{|c|}{ Abundantes } & & & & & & & & & & & & & & \\
\hline & & & \multirow{3}{*}{\multicolumn{2}{|c|}{ Localização }} & \multicolumn{3}{|c|}{ Entre todas as lamelas } & & & & & & & & & & & & & & \\
\hline & & & & & \multicolumn{3}{|c|}{ Entre as lamelas externas } & & & & & & & & & & & & & & \\
\hline & & & & & \multicolumn{3}{|c|}{ Apenas na periferia } & & & & & & & & & & & & & & \\
\hline & & & \multirow{2}{*}{\multicolumn{2}{|c|}{ Disposição }} & \multicolumn{3}{|c|}{ Aleatórios } & & & & & & & & & & & & & & \\
\hline & & & & & \multicolumn{3}{|c|}{ Em grupos } & & & & & & & & & & & & & & \\
\hline & & \multicolumn{6}{|c|}{ Ausentes } & & & & & & & & & & & & & & \\
\hline & & \multirow{2}{*}{\multicolumn{3}{|c|}{ Agregadas }} & Colônia & & & & & & & & & & & & & & & & \\
\hline & . & & & & Biofilm & & & & & & & & & & & & & & & & \\
\hline & 苂 & & & & Nas po & prçõe & s centrais & & & & & & & & & & & & & & \\
\hline & & & _ocalização & & Apenas & s na & periferia & & & & & & & & & & & & & & \\
\hline & & & & & & Norm & & & & & & & & & & & & & & & \\
\hline & & & & & Atro & fia a & acinar & & & & & & & & & & & & & & \\
\hline & & $\bar{\sigma}$ & & & Necro & ose t & tecidual & & & & & & & & & & & & & & \\
\hline & & 묻 & & & & & ormais & & & & & & & & & & & & & & \\
\hline & & $\frac{\pi}{0}$ & & & & $\overline{\mathrm{Com}}$ & dilatação & & & & & & & & & & & & & & \\
\hline لب & & :응 & $\frac{0}{0}$ & & Fnitélio & de & Células & & & & & & & & & & & & & & \\
\hline$\stackrel{0}{\Sigma}$ & 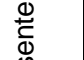 & & & & evestime & ento & Células & & & & & & & & & & & & & & \\
\hline 요 & $\stackrel{0}{2}$ & & & & & & $\begin{array}{l}\text { Células } \\
\text { mucosas }\end{array}$ & & & & & & & & & & & & & & \\
\hline U & & & & & & Fibr & roso & & & & & & & & & & & & & & \\
\hline & & $\stackrel{P}{i}$ & Carac & erris & sticas & Fro & uxo & & & & & & & & & & & & & & \\
\hline & & $\cdot \frac{\vec{c}}{0}$ & & & & & Mononuclear & & & & & & & & & & & & & & \\
\hline & & $\begin{array}{l}0 \\
ㅇ ㅡ ㅇ ~\end{array}$ & 응 $\frac{\overline{0}}{\frac{0}{\pi}}$ & & onstituilç & & Polimorfonuclear & & & & & & & & & & & & & & \\
\hline & & $\stackrel{8}{-}$ & 衰 & & & & Difusa & & & & & & & & & & & & & & \\
\hline & & & & & IStribulç & & Focal & & & & & & & & & & & & & & \\
\hline & & & & & Ausente & & & & & & & & & & & & & & & & \\
\hline
\end{tabular}


Tabela 3 - Modelo de tabela idealizado para registro dos achados microscópicos referentes aos cortes corados em Brown e Brenn (B.B.)

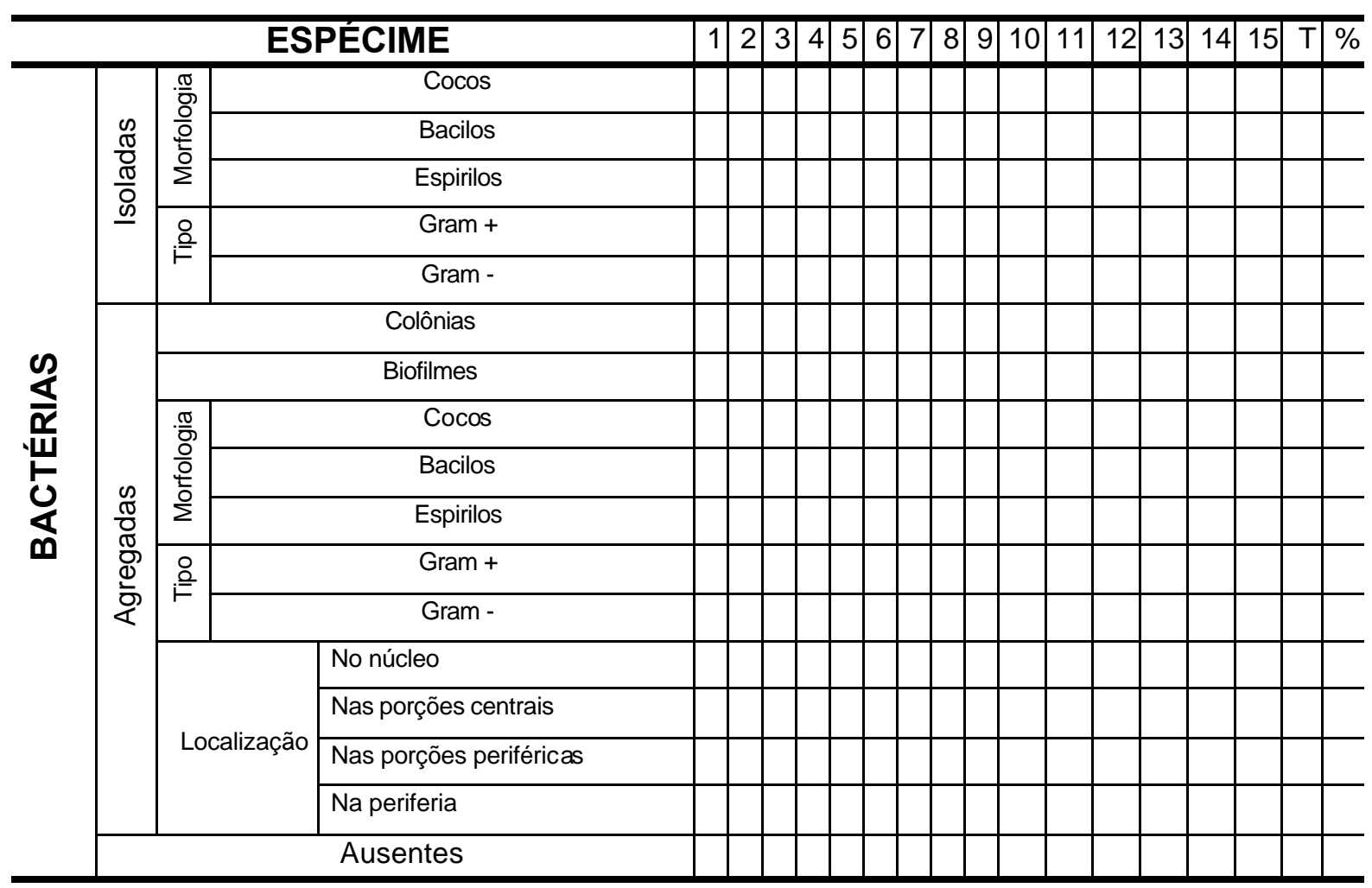


O microscópio de polarização distingue-se dos demais pela sua óptica cujos cristais devem ser isentos de tensão. Além do mais, as objetivas devem ser do tipo neofluar que permitem maiores aberturas numéricas, oferecendo mais brilho e maior poder de resolução. Estas objetivas têm anéis que permitem a centralização de sua óptica com o condensador e o objeto. Os filtros polarizadores são em número de dois: polarizador e analisador. O filtro polarizador é montado de tal sorte que permita rotação e movimentação a fim de ser colocado ou removido no trajeto da luz, quando a luz já trafegou através desse polarizador a radiação é polarizada perpendicularmente em um único plano; o filtro analisador é situado acima das objetivas e abaixo das oculares, permitindo que a luz vinda plano-polarizada (com vetor elétrico vibrando em um só plano) encontre o plano de polarização do analisador perpendicular à sua direção de vibração, absơvendo-a. Da mesma forma, haverá passagem de luz pelo analisador toda vez que os planos de polarização estiverem inclinados um com respeito ao outro; nestes casos a intensidade de luz observada é proporcional ao ângulo formado pelos planos do polarizador e analisador, ou seja, a intensidade será máxima quando eles forem paralelos entre $\mathrm{si}^{123}$.

Ao microscópio de luz polarizada as lâminas sem coloração foram analisadas em data distinta, agendada de acordo com a disponibilidade do Departamento de Morfologia, Estomatologia e Fisiologia da Faculdade de Odontologia de Ribeirão Preto, FORP-USP. Os dados coletados foram demonstrados em tabela elaborada previamente, como o exemplo que segue: 
Tabela 4 - Modelo de tabela idealizado para registro dos achados microscópicos referentes aos cortes sem coloração, examinados ao microscópio de luz polarizada

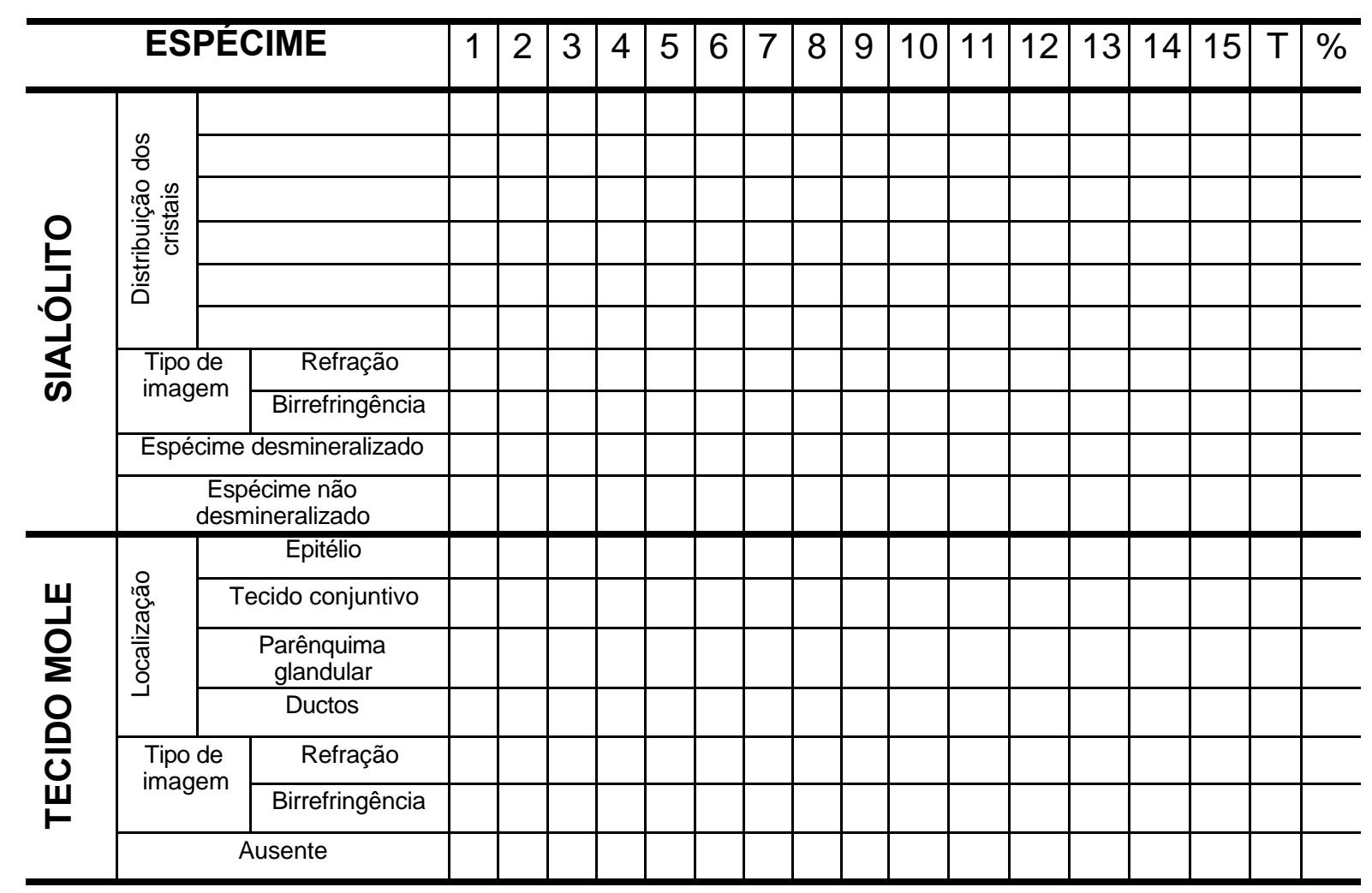

Para a análise microscópica óptica comum, foi utilizado um microscópio Leica-DMLSI 198; para a microscopia óptica de luz polarizada foi utilizado um microscópio Jenaval Carl Zeiss - Jena, Oberkochen, German. As fotomicrografias foram obtidas pelo fotomicroscópio Carl Zeiss tanto à microscopia óptica comum quanto à microscopia óptica de luz polarizada. 


\subsection{ANÁLISE ESTATÍSTICA:}

Para a análise dos dados obtidos foi empregada estatística descritiva com uso de tabelas com dados de freqüências absolutas e relativas. Após 21 dias todas as análises foram repetidas para aplicação do índice Kappa ${ }^{64}$. Foram escolhidos os seguintes critérios para a aplicação deste índice:

a) Padrão de mineralização em hematoxilina-eosina de Harris (H.E.);

b) Classificação quanto à norfologia das bactérias agregadas na coloração de Brown e Brenn (B.B.);

c) Distribuição dos cristais nos padrões estabelecidos, em microscopia de luz polarizada;

d) Tipo de imagem observado dentro dos padrões estabelecidos: refração ou birrefringência.

O índice Kappa ${ }^{64}$ preconiza uma avaliação do nível de concordância de um mesmo examinador, conforme a figura abaixo:

Coeficiente Kappa

$$
<0,00
$$

$0,00-0,20$

$0,21-0,40$

$0,41-0,60$

$0,61-0,80$

$0,81-1,00$

\section{Nível de concordância}

Baixo

Médio

Moderado

Substancial

Quase perfeito 


\section{RESULTADOS}

Neste capítulo, os dados obtidos serão apresentados levando-se em conta a morfologia dos sialólitos e a presença de bactérias, a partir da análise microscópica óptica comum de cortes de tecidos corados pelas técnicas da hematoxilina-eosina de Harris e de Brown e Brenn, como também sua morfologia ao microscópio de luz polarizada. Foram analisados quinze espécimes. A caracterização da amostra foi feita por meio dos dados coletados nas fichas de envio para análise do material.

\subsection{CARACTERIZAÇÃO DA AMOSTRA:}

Houve discreta predominância do gênero feminino (60\%) sobre o masculino (40\%). Quanto à fase da vida, a alteração ocorreu principalmente entre a terceira e sétima décadas $(66,6 \%)$ de vida, observando-se apenas um caso na primeira década $(6,6 \%)$ e dois casos na oitava década $(13,3 \%)$. Em dois casos $(13,3 \%)$ não havia relato sobre a idade do paciente.

Quanto à localização da lesão, dez casos $(66,6 \%)$ ocorreram na glândula submandibular, um único caso na parótida $(6,6 \%)$ e dois casos em glândulas salivares menores $(13,3)$. Em dois casos $(13,3 \%)$ não havia relato da localização da lesão. 
A sintomatologia dolorosa com tumefação aguda estava presente em um único caso $(6,6 \%)$; tumefação transitória sem sintomatologia dolorosa observourse em três casos (20\%). Em onze casos (73,3\%) não havia informações quanto à sintomatologia e à presença de tumefação.

Quanto ao tempo de evolução houve grande variação: de 6 meses a 20 anos, sendo que 11 casos $(73,3 \%)$ não relataram o tempo de evolução das lesões.

Três espécimes (20\%) estavam relacionados à presença de drenagem ora de coleção purulenta, ora de material viscoso e, em um caso, à presença de prótese total $(6,6 \%)$. Houve apenas um relato de imagem radiográfica como massa radiopaca na região do ducto da glândula. Sete casos $(46,6 \%)$ não apresentaram qualquer descrição de história clínica. 
Tabela 1 - Dados gerais da amostra resgatados a partir de resumos clínicos obtidos na requisição do exame anatomopatológico que é enviado juntamente com a peça cirúrgica

\begin{tabular}{|c|c|c|c|c|c|}
\hline \multirow{2}{*}{ GÊNERO } & & $\mathbf{T}$ & $\%$ \\
\hline & \multicolumn{3}{|l|}{$\begin{array}{l}\text { Masculino } \\
\text { Feminino }\end{array}$} & $\begin{array}{l}6 \\
9\end{array}$ & $\begin{array}{l}40,0 \\
60,0\end{array}$ \\
\hline IDADE & $\begin{array}{l}\text { Primeira déc } \\
\text { Segunda dé } \\
\text { Terceira déc } \\
\text { Quarta déca } \\
\text { Quinta déca } \\
\text { Sexta décao } \\
\text { Sétima déca } \\
\text { Oitava déca } \\
\text { Não consto }\end{array}$ & $\begin{array}{l}\text { cada } \\
\text { cada } \\
\text { cada } \\
\text { ada } \\
\text { da } \\
\text { da } \\
\text { da } \\
\text { da } \\
d\end{array}$ & & $\begin{array}{l}1 \\
- \\
3 \\
1 \\
1 \\
2 \\
3 \\
2 \\
2\end{array}$ & $\begin{array}{r}6,6 \\
- \\
20,0 \\
6,6 \\
6,6 \\
13,3 \\
20,0 \\
13,3 \\
13,3\end{array}$ \\
\hline LOCALIZAÇÃO & $\begin{array}{l}\text { Glândula pa } \\
\text { Glândula sul } \\
\text { Glândula sul } \\
\text { Glândulas s } \\
\text { Não constou }\end{array}$ & $\begin{array}{l}\text { rótida } \\
\text { bmandibu } \\
\text { blingual } \\
\text { alivares a } \\
\text { a }\end{array}$ & ssórias & $\begin{array}{c}1 \\
10 \\
- \\
2 \\
2\end{array}$ & $\begin{array}{r}6,6 \\
66,6 \\
- \\
13,3 \\
13,3\end{array}$ \\
\hline \multirow{5}{*}{ 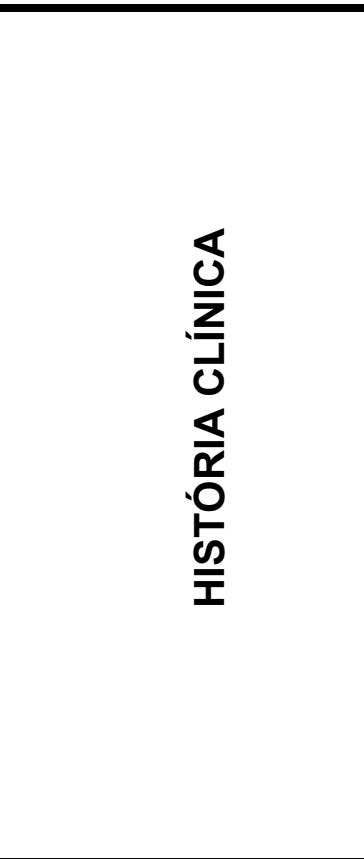 } & Sintomatologia & \multicolumn{2}{|c|}{\begin{tabular}{l|l} 
a & Ausente \\
Presente \\
Não constou
\end{tabular}} & $\begin{array}{c}3 \\
1 \\
11\end{array}$ & $\begin{array}{r}20,0 \\
6,6 \\
73,3\end{array}$ \\
\hline & Tumefação & \multicolumn{2}{|c|}{$\begin{array}{l}\text { Aguda } \\
\text { Constante } \\
\text { Transitória } \\
\text { Não constou }\end{array}$} & $\begin{array}{c}1 \\
- \\
3 \\
11\end{array}$ & $\begin{array}{r}6,6 \\
- \\
20,0 \\
73,3\end{array}$ \\
\hline & \multicolumn{2}{|c|}{ Tempo de evolução } & \begin{tabular}{|l|}
20 anos \\
15 anos \\
6 anos \\
6 meses \\
Não constou
\end{tabular} & $\begin{array}{c}1 \\
1 \\
1 \\
1 \\
11\end{array}$ & $\begin{array}{r}6,6 \\
6,6 \\
6,6 \\
6,6 \\
73,3\end{array}$ \\
\hline & \multicolumn{2}{|c|}{$\begin{array}{l}\text { Fatores etiológicos } \\
\text { associados }\end{array}$} & $\begin{array}{l}\text { Drenagem purulenta } \\
\text { Drenagem de substância viscosa e esbranquiçada } \\
\text { Presença de prótese total } \\
\text { Não constou }\end{array}$ & $\begin{array}{c}2 \\
1 \\
1 \\
11\end{array}$ & $\begin{array}{r}13,3 \\
6,6 \\
6,6 \\
73,3\end{array}$ \\
\hline & \multicolumn{3}{|c|}{ SEM RELATOS CLINICOS } & 7 & 46,6 \\
\hline RELATOS & \multicolumn{3}{|c|}{ Massa radiopaca na regiẫo do ducto da glândula } & 1 & $\overline{6,6}$ \\
\hline RADIOGRAFICOS & \multicolumn{3}{|l|}{ Sem relatos } & 14 & 93,3 \\
\hline
\end{tabular}




\subsection{ANÁLISE MICROSCÓPICA:}

\subsubsection{Ao microscópio de luz comum:}

$\mathrm{Na}$ coloração de hematoxilina-eosina de Harris (H.E.) os sialólitos apresentavam-se eosinófilos permeados por áreas basofílicas. Em dez casos $(66,6 \%)$ observoutse padrão de organização lamelar e concêntrico, sendo quatro $(26,6 \%)$ com um único centro e seis $(40 \%)$ com mais de um centro de mineralização; em quatro casos $(26,6 \%)$ observourse aspecto homogêneo de mineralização e em um único espécime (6,6\%) padrão misto de mineralização. As Figuras 1, 2, 3, 4 e 5 evidenciam os principais achados relativos a essa análise.

No aumento com imersão, identificou-se a presença de pequenas estruturas cristalóides em oito casos (53,3\%), em sete destes $(46,6 \%)$, os cristalóides apareciam aleatoriamente e, em um caso (6,6\%), em grupos. Quanto à localização, em três casos (20\%) os cristalóides apareciam em todas as porções do sialólito, em quatro casos $(26,6 \%)$ apresentavam essas estruturas apenas nas lamelas mais externas e um único espécime (6,6\%) mostrou cristalóides na periferia.

Em todos os casos (100\%) foram observados aglomerados bacterianos actinomices símile (actinomices-like) exibindo estreita relação com os fragmentos, particularmente as camadas mais externas desses fragmentos, e, em algumas ocasiões, organizadas em biofilmes microbianos (Figuras 7, 8a e 8b). 
$\mathrm{Na}$ coloração de Brown e Brenn esses aglomerados bacterianos mostraram-se com discreta predominância de Gram-positivos com relação aos Gram-negativos (Figuras 9, 10, 11 e 12). Oito casos (53,3\%) sem predominância entre os grupos apresentaram colônias dos dois tipos: Gram-positivas e Gramnegativas; em cinco outros (33,3\%) se observou predominância de Gram-positivas e dois (13,3\%) com predominância de Gram-negativas.

A grande maioria dos aglomerados bacterianos estava presente nas porções periféricas dos espécimes. Em apenas um caso $(6,6 \%)$ notourse a presença de colônias no núcleo central do sialólito e em outros dois $(13,3 \%)$ essas colônias estavam presentes também entre as lamelas próximas do núcleo; nestes três últimos casos (20\%) não houve predominância entre Gram-positivas e Gram-negativas para essa região do espécime.

Os morfotipos bacterianos observados com maior freqüência nos espécimes foram cocos e espirilos (43,3\% e 38,3\% respectivamente), bacilos também foram observados (Figura 13), porém em menor freqüência $(18,3 \%)$. As bactérias Gram-positivas apresentavam-se mais individualizadas, em azul ou roxo, enquanto as Gram-negativas em forma de borrões avermelhados.

Dos 15 espécimes examinados apenas quatro (26,6\%) apresentaram tecido mole do tipo conjuntivo e glandular (Figuras 5, 6 e 8). Enquanto tecido glandular foi observado nos quatro casos, tecido conjuntivo fibroso foi observado em dois casos e tecido conjuntivo frouxo nos outros dois.

Dilatação ductal foi observada nos quatro casos $(100 \%, n=4)$ e atrofia acinar em dois espécimes $(50 \%, n=4)$. O epitélio de revestimento dos ductos dilatados apresentou células escamosas, oncocíticas e mucosas. Em um espécime observaram-se os três tipos de alteração no epitélio de revestimento; outro caso 
apresentou-se com células escamosas e oncocíticas; um deles apresentou apenas células escamosas e, ainda, outro apresentou epitélio de revestimento com aspecto de normalidade.

O infiltrado inflamatório observado constituiurse, predominantemente, de mononucleares $(75 \%, n=4)$, com distribuição difusa em todos os espécimes. 
Tabela 2 - Registro dos achados microscópicos referentes aos cortes corados em hematoxilina-eosina de Harris (H.E.)

\begin{tabular}{|c|c|c|c|c|c|c|c|c|c|c|c|c|c|c|c|c|c|c|c|c|c|c|c|}
\hline \multicolumn{7}{|c|}{ ESPECIME } & 1 & 2 & 3 & 4 & 5 & 6 & 7 & 8 & 9 & 10 & 11 & 12 & 13 & 14 & 15 & $\mathbf{T}$ & $\%$ \\
\hline \multirow{17}{*}{$\frac{\text { 음 }}{\frac{1}{0}}$} & \multirow{5}{*}{ 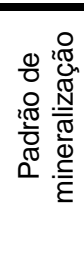 } & \multirow{3}{*}{ 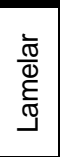 } & \multicolumn{4}{|c|}{ Um só centro de mineralização } & & & & $x$ & $\mathrm{X}$ & & & & & $X$ & & & & $X$ & & 4 & 26,6 \\
\hline & & & \multicolumn{4}{|c|}{ Mais de um centro de mineralização } & $x$ & & & & & $x$ & & & & & $x$ & & & & $x$ & 4 & 26,6 \\
\hline & & & \multicolumn{4}{|c|}{ Um centro maior e vários menores } & & & $x$ & & & & & & & & & $X$ & & & & 2 & $\overline{13,3}$ \\
\hline & & \multicolumn{5}{|c|}{ Homogêneo } & & $x$ & & & & & $x$ & $x$ & & & & & $x$ & & & 4 & 26,6 \\
\hline & & \multicolumn{5}{|c|}{ Misto } & & & & & & & & & $x$ & & & & & & & 1 & 6,6 \\
\hline & \multirow{8}{*}{ 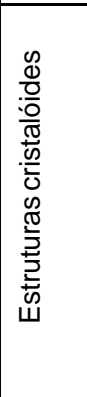 } & \multirow{7}{*}{ 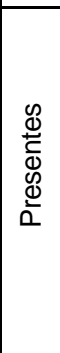 } & \multirow{2}{*}{\multicolumn{2}{|c|}{ Freqüência }} & \multirow{2}{*}{\multicolumn{2}{|c|}{\begin{tabular}{|l|} 
Escassos \\
Abundantes
\end{tabular}}} & $x$ & & $\mathrm{X}$ & $x$ & $x$ & & & & $x$ & $X$ & $X$ & & & $X$ & & 8 & 53,3 \\
\hline & & & & & & & & & & & & & & & & & & & & & & - & - \\
\hline & & & \multirow{3}{*}{\multicolumn{2}{|c|}{ Localização }} & \multicolumn{2}{|c|}{ Entre todas as lamelas } & & & $x$ & & & & & & & $x$ & $x$ & & & & & 3 & 20,0 \\
\hline & & & & & \multicolumn{2}{|c|}{\begin{tabular}{|l} 
Entre as lamelas externas \\
\end{tabular}} & $x$ & & & $x$ & & & & & $x$ & & & & & $x$ & & 4 & 26,6 \\
\hline & & & & & \multicolumn{2}{|c|}{ Apenas na periferia } & & & & & $x \mid$ & & & & & & & & & & & 1 & 6,6 \\
\hline & & & \multirow{2}{*}{\multicolumn{2}{|c|}{ Disposição }} & \multicolumn{2}{|c|}{ Aleatórios } & $\mathrm{X}$ & & $\mathrm{X}$ & $x$ & $x$ & & & & $x$ & $X$ & $x$ & & & & & 7 & 46,6 \\
\hline & & & & & \multicolumn{2}{|c|}{ Em grupos } & & & & & & & & & & & & & & $x$ & & 1 & $\overline{6,6}$ \\
\hline & & \multicolumn{5}{|c|}{ Ausentes } & & $x$ & & & & $x$ & $x$ & $\mathrm{X}$ & & & & $x$ & $\mathrm{X}$ & & $\mathrm{X}$ & 7 & 46,6 \\
\hline & & & & & Colôn & & $\mathrm{X}$ & $x$ & $\mathrm{X}$ & $x$ & $x \mid$ & $x$ & $\mathrm{X}$ & $\mathrm{x}$ & $x$ & $X$ & $x$ & $\mathrm{x}$ & $\mathrm{x}$ & $x$ & $\mathrm{x}$ & 15 & 100,0 \\
\hline & $\frac{\pi}{\frac{\pi}{2}}$ & & Agrega & & Biofiln & & $\mathrm{x}$ & & & $\mathrm{x}$ & & $\mathrm{x}$ & & $\mathrm{x}$ & $\mathrm{x}$ & & $\mathrm{x}$ & & & $\mathrm{x}$ & & 7 & 46,6 \\
\hline & $\underset{\tilde{D}}{\tilde{D}}$ & & 1 oliz & & Nas $p$ & orções centrais & $x$ & $x$ & $x$ & $x$ & & $x$ & $\mathrm{X}$ & & $x$ & & & $x$ & $x$ & $x$ & $\mathrm{x}$ & 11 & 73,3 \\
\hline & & & Locallze & & Apena & s na periferia & & & & & $\mathrm{x}$ & & & $\mathrm{X}$ & & $\mathrm{X}$ & $x$ & & & & & 4 & 26,6 \\
\hline & & & & & Nor & mal & & & & & & & & & & $\mathrm{X}$ & $x$ & & & & & 2 & 50,0 \\
\hline & & & & & Atrofia & acinar & & & & & & $x$ & & $\mathrm{X}$ & & & & & & & & 2 & 50,0 \\
\hline & & $\frac{\pi}{5}$ & & & Vecrose & tecidual & & & & & & & & & & & & & & & & - & - \\
\hline & & 胥 & & & & Normais & & & & & & & & & & & & & & & & - & - \\
\hline & & $\frac{0}{ㅇ ㅡ ㅇ ~}$ & \% & & Co & m dilatação & & & & & & $x$ & & $x$ & & $X$ & $x$ & & & & & 4 & 100,0 \\
\hline $\overrightarrow{\mathbf{n}}$ & $\widehat{F}$ & $\stackrel{\mathbb{\Phi}}{\vdash}$ & $\frac{0}{0}$ & & & Células escamosas & & & & & & $\mathrm{x}$ & & & & $x$ & $x$ & & & & & 3 & 75,0 \\
\hline$\underline{\Sigma}$ & $\subseteq$ & & & $\begin{array}{l}\text { Eplte } \\
\text { reves }\end{array}$ & $\begin{array}{l}\text { imento } \\
\text { imente }\end{array}$ & Células oncocíticas & & & & & & $x$ & & & & & $x$ & & & & & 2 & 50,0 \\
\hline 8 & $\begin{array}{l}\bar{T} \\
\\
D \\
0\end{array}$ & & & & & Células mucosas & & & & & & $x$ & & & & & & & & & & 1 & 25,0 \\
\hline 붕 & $\stackrel{\Phi}{0}$ & & Caract & aŕctic & & Fibroso & & & & & & $x$ & & & & $\mathrm{X}$ & & & & & & 2 & 50,0 \\
\hline Ш & & 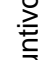 & Caract & eristic & & Frouxo & & & & & & & & $\mathrm{X}$ & & & $x$ & & & & & 2 & 50,0 \\
\hline & & : & & Con & tituicว̃ & Mononuclear & & & & & & & & $\mathrm{X}$ & & $\mathrm{X}$ & $\mathrm{X}$ & & & & & 3 & 75,0 \\
\hline & & 음 & 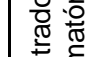 & & 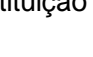 & Polimorfonuclear & & & & & & $x$ & & & & & & & & & & 1 & 25,0 \\
\hline & & $\stackrel{\mathscr{\Phi}}{\bullet}$ & 竧焉 & Rict & طนทีก̃̃ & Difusa & & & & & & $x$ & & $\mathrm{X}$ & & $X$ & $x$ & & & & & 4 & 100,0 \\
\hline & & & & DISt & bulçao & Focal & & & & & & & & & & & & & & & & - & - \\
\hline & & & & Auser & $e(n=1$ & & $X$ & $x$ & $\mathrm{X}$ & $x$ & $\mathrm{X}$ & & $\mathrm{x}$ & & $x$ & & & $x$ & $x$ & $\mathrm{X}$ & $x$ & 11 & 73,3 \\
\hline
\end{tabular}


Tabela 3 - Registro dos achados microscópicos referentes aos cortes corados pela técnica de Brown e Brenn

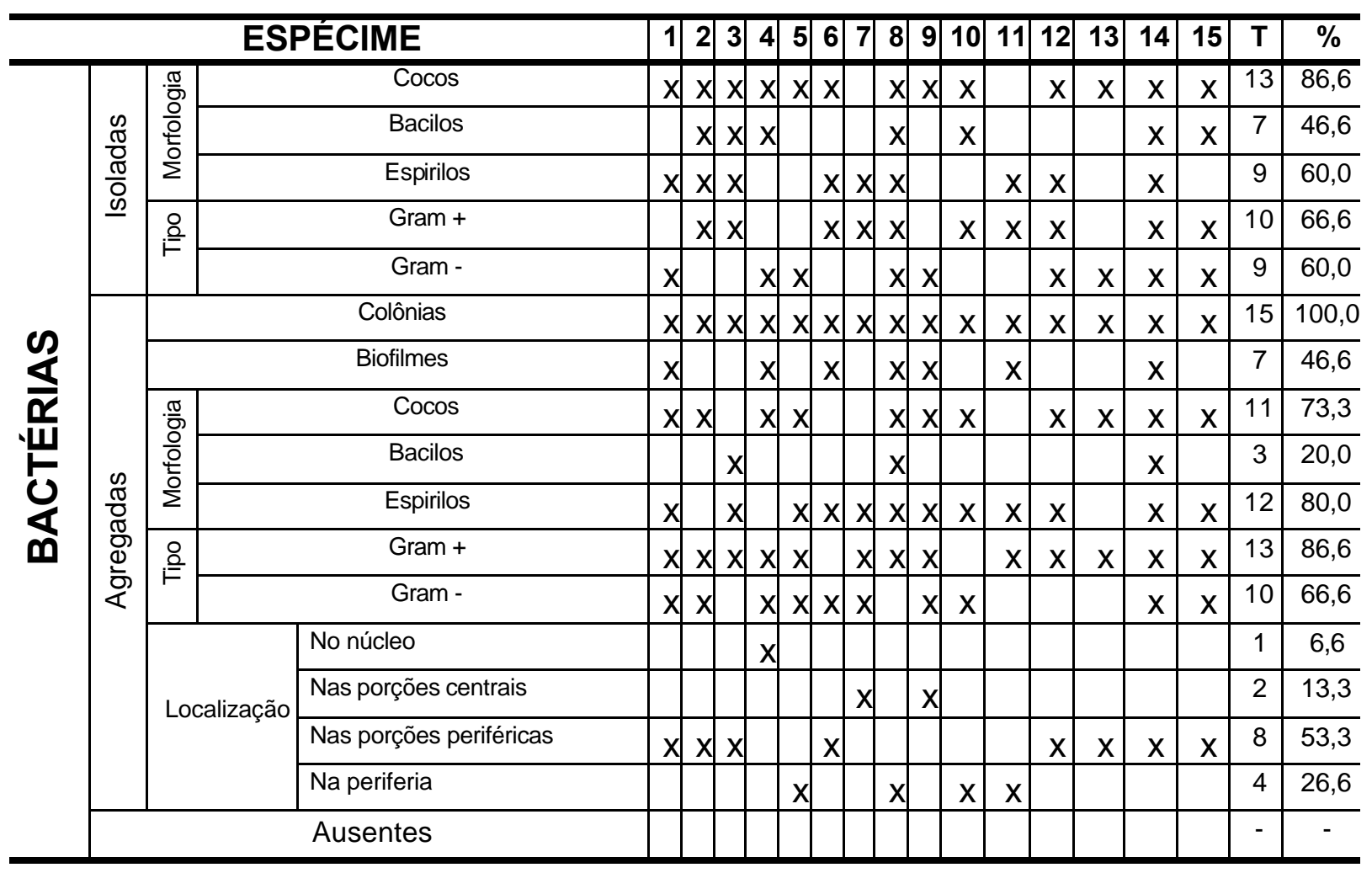



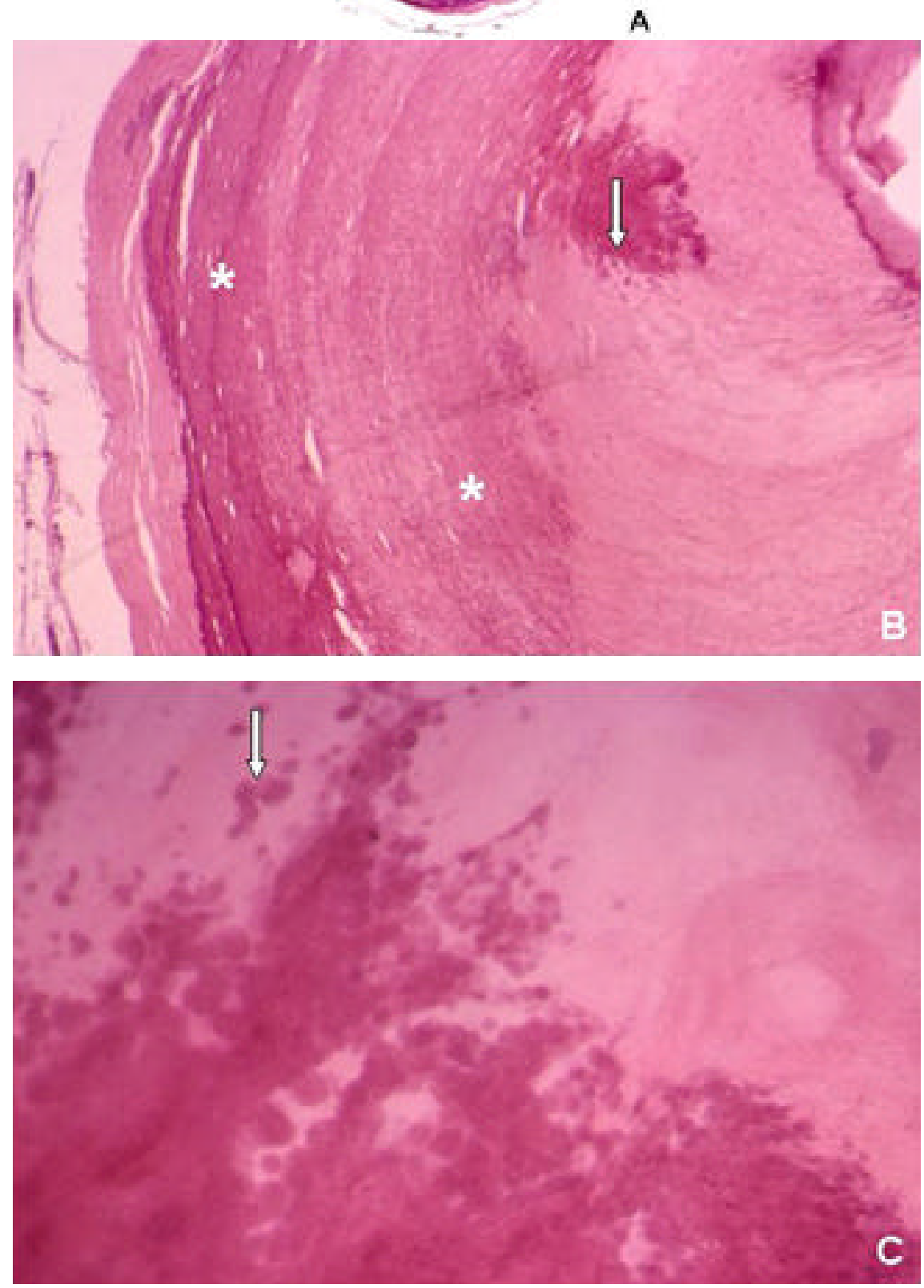

Figura 1 - Sialólito com formação concêntrica única revelando padrões diferentes de mineralização, incluindo várias camadas lineares $\left(^{*}\right)$ e formações tipo calcosferitas (setas), (H.E.; aumento original: $A=4 X ; B=10 X ; C=100 X)$ 

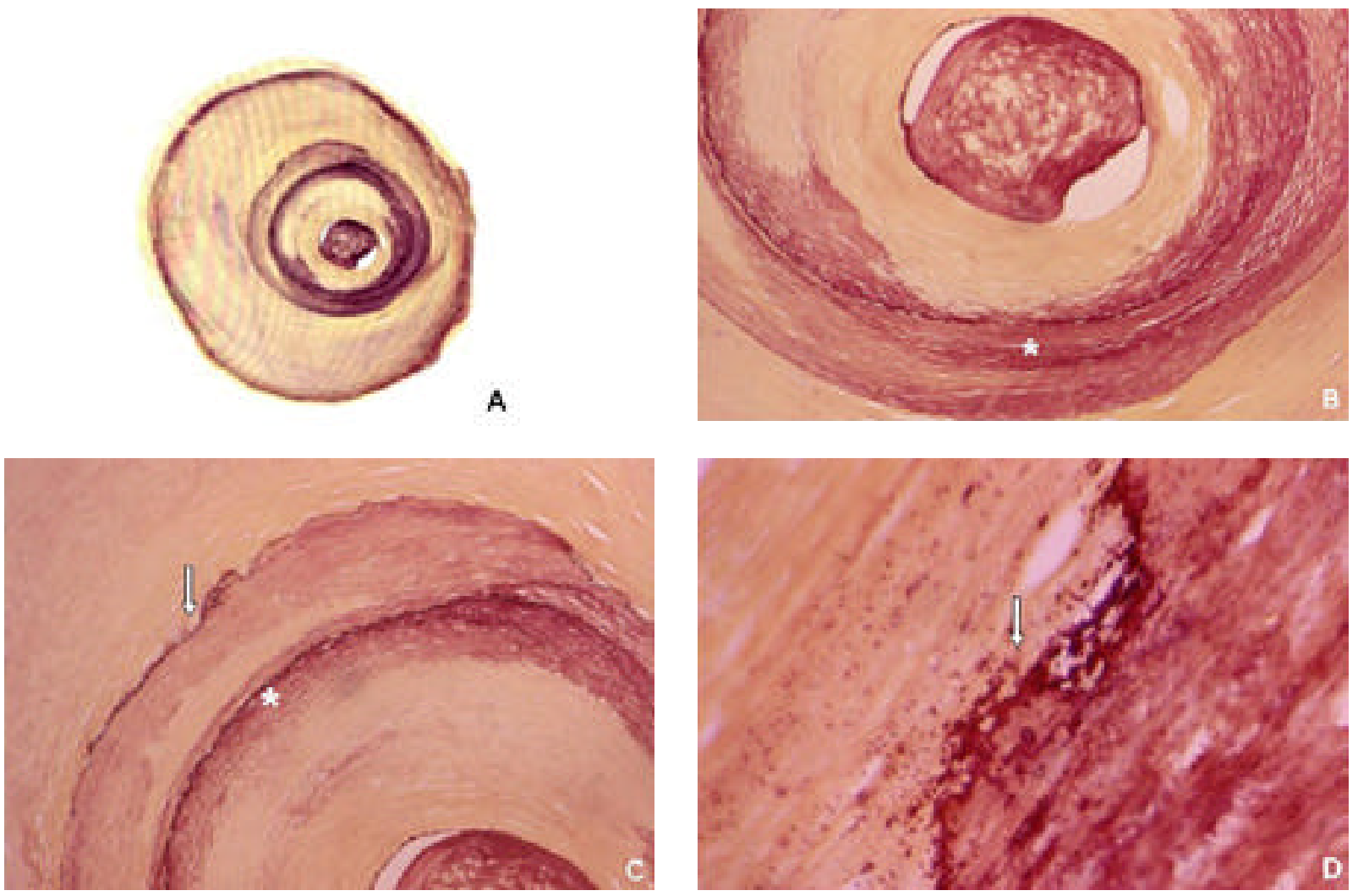

Figura 2 - Sialólito, o mesmo da figura anterior, observado pela coloração de Brown e Brenn, com formação concêntrica única revelando padrões diferentes de mineralização, incluindo várias camadas lineares $\left(^{*}\right)$ e formações tipo calcosferitas (setas), (B.B.; aumento original: $A=4 X ; B=10 X ; C=10 X$; $D=100 X)$ 

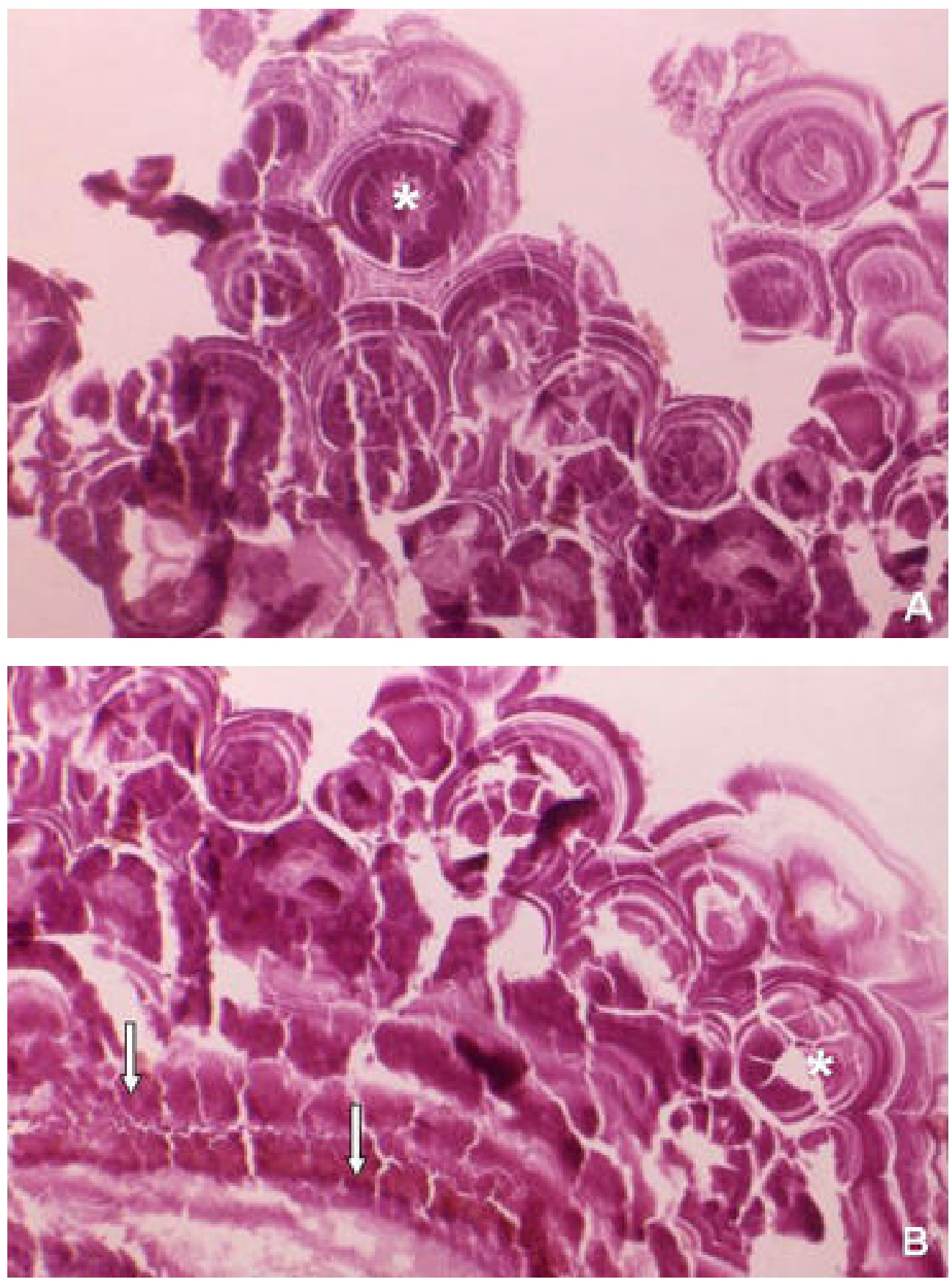

Figura 3 - Padrão com vários centros de mineralização em múltiplas pequenas formações $\left({ }^{*}\right)$ em sua periferia. Em B, internamente o sialólito apresenta uma organização lamelar mais regular, linear e maior (setas), (H.E.; aumento original: $A=40 X ; B=40 X$ ) 

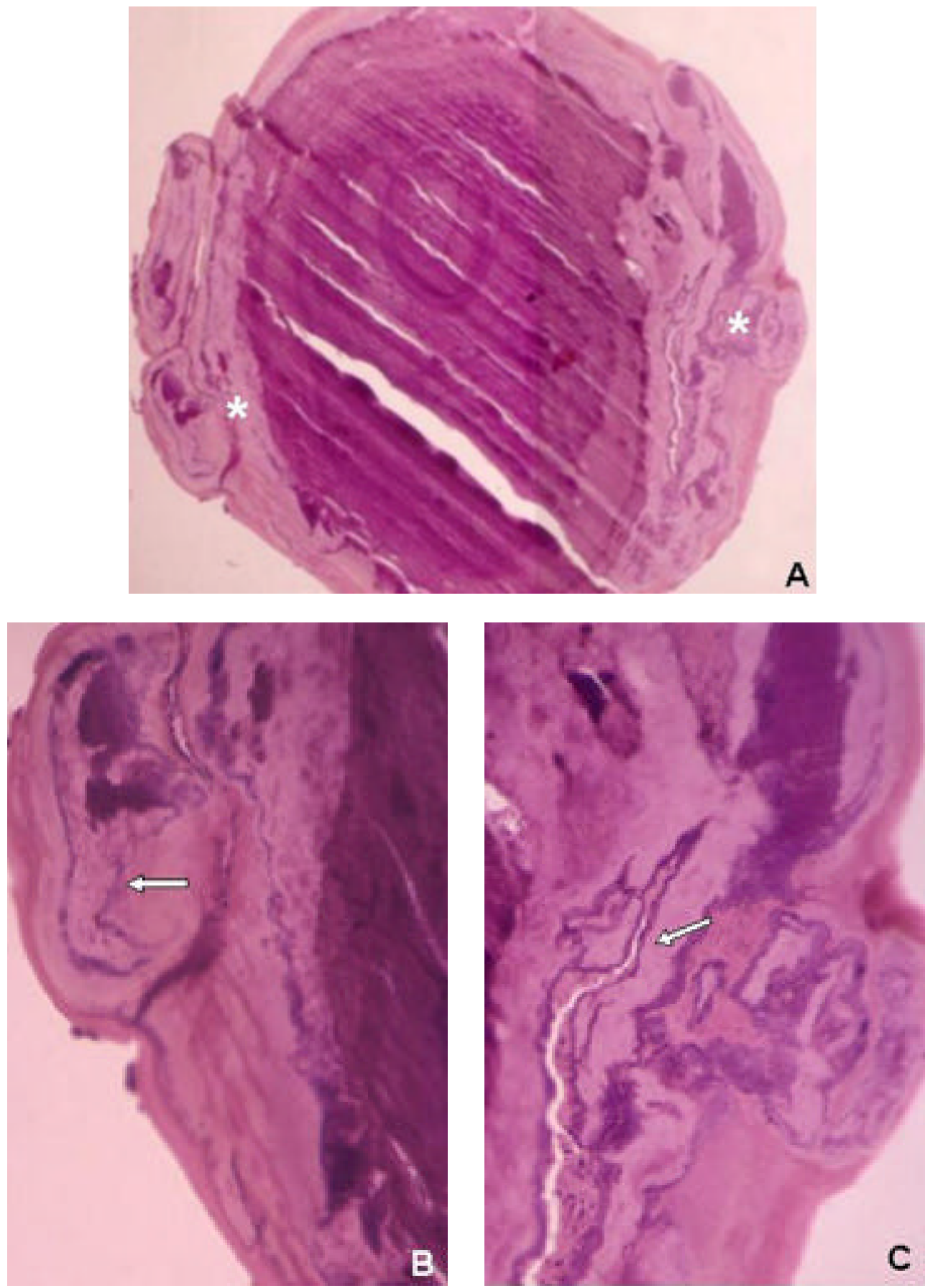

Figura 4 - Sialólito com formação concêntrica maior revelando padrões periféricos diferentes de mineralização, sugerindo união e fusão com outras formações menores $\left({ }^{*}\right)$, biofilmes microbianos entre suas camadas de aposição (setas), (H.E.; aumento original: $A=40 X ; B=100 X ; C=100 X$ ) 

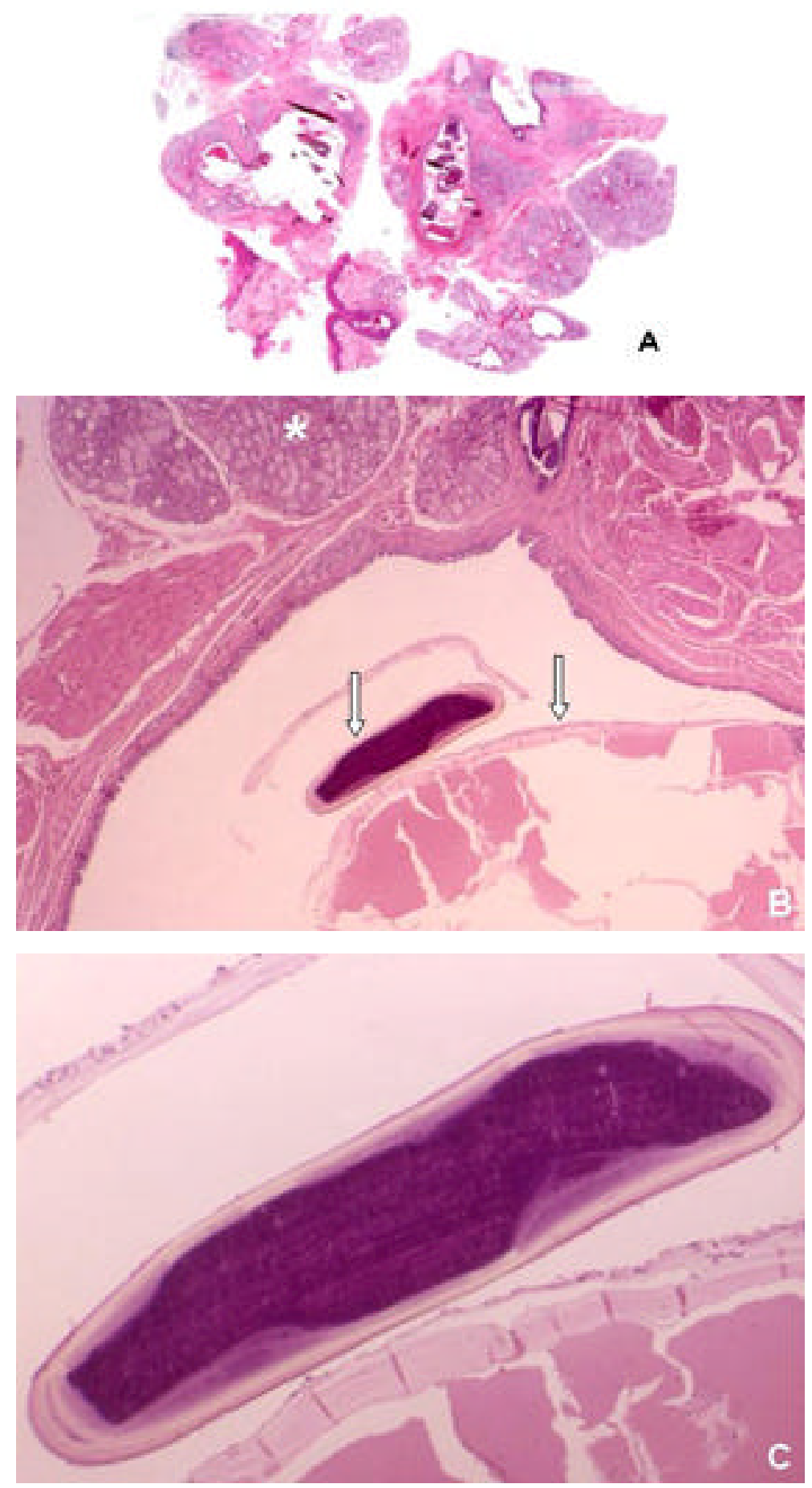

Figura 5 - Sialólito em ducto excretor dilatado da glândula observada nos cortes examinados $\left(^{\star}\right)$. O sialólito se constituía de várias formações unidas. Os padrões de cada formação eram diferentes (setas), (H.E.; aumento original: $A=4 X ; B=10 X ; C=40 X)$ 

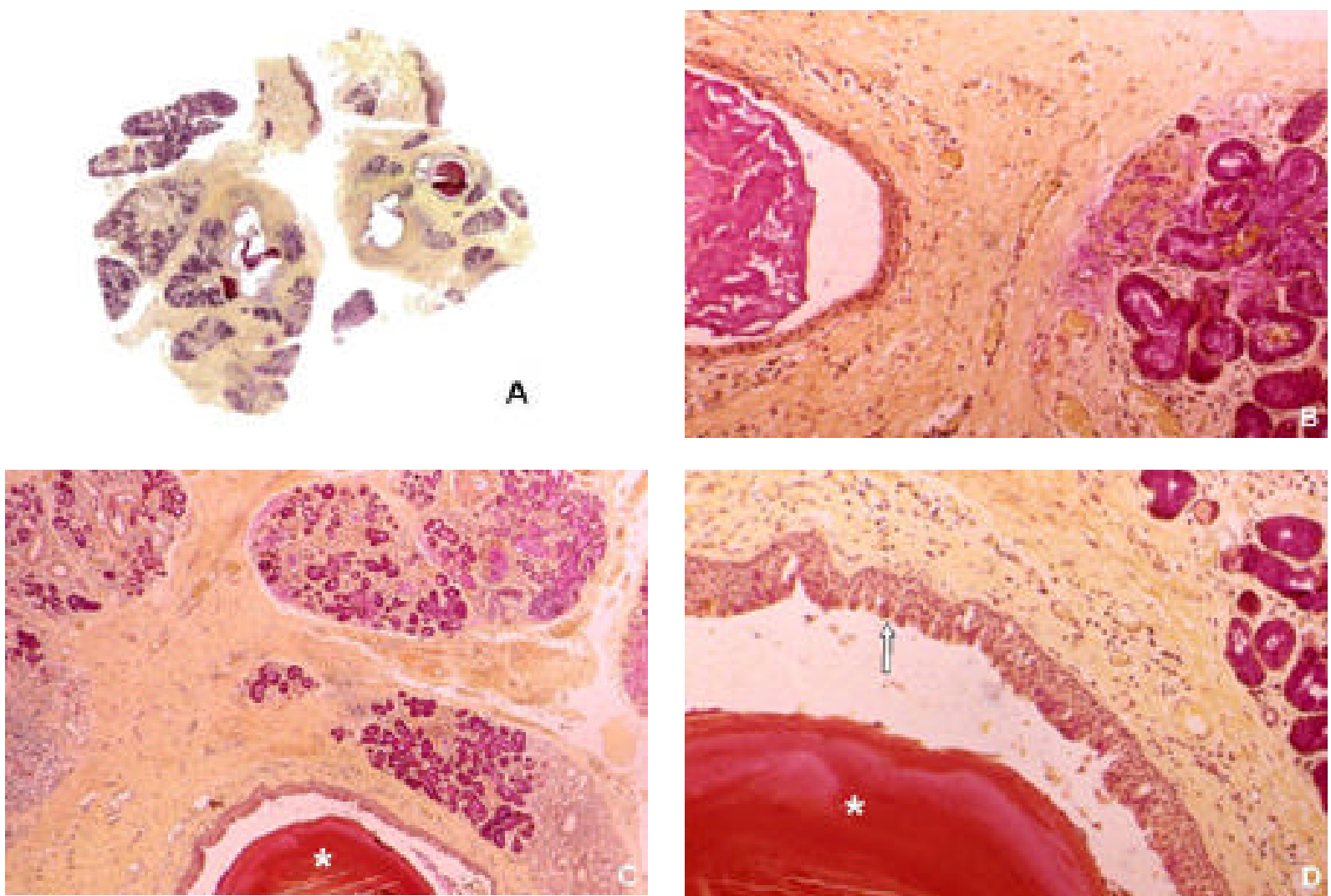

Figura 6 - Glândula salivar com ducto excretor dilatado pela presença do sialólito $\left(^{*}\right)$ com metaplasia escamosa de seu epitélio (seta), (B.B.; aumento original: $A=4 X ; B=40 X ; C=40 X ; D=100 X$ ) 

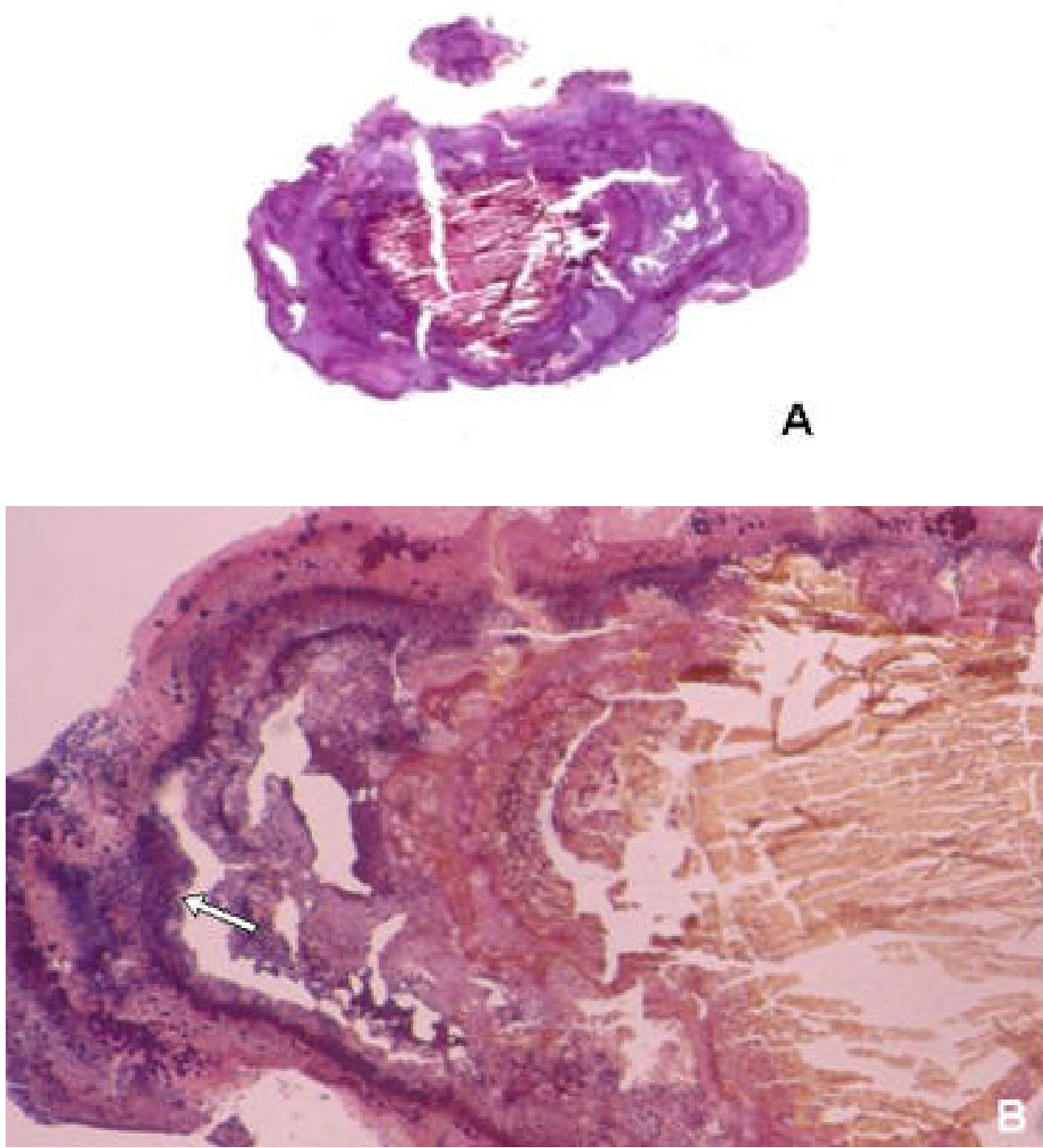

Figura 7 - Sialólito com formação concêntrica maior revelando padrões periféricos diferentes de mineralização com biofilmes microbianos entre suas camadas de aposição (seta), (B.B.; aumento original: $A=4 X ; B=40 X$ ) 

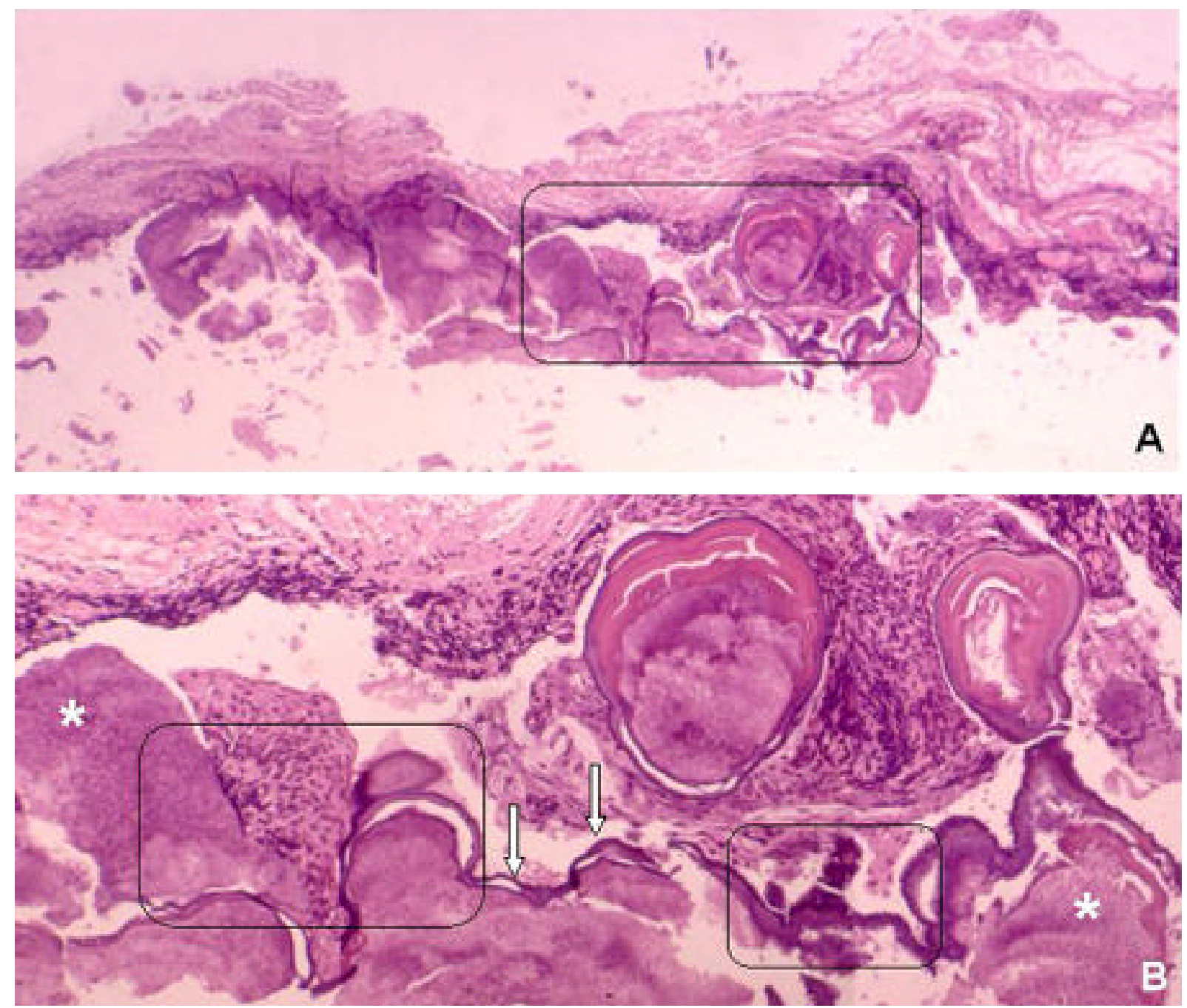

Figura 8a - Sialólitos em ducto excretor com intensa desorganização epitelial associada à rica presença de bactérias em forma de aglomerados $\left(^{*}\right) \mathrm{e}$ biofilmes microbianos (setas), (H.E.; aumento original: $A=10 X ; B=40 X$ ) 

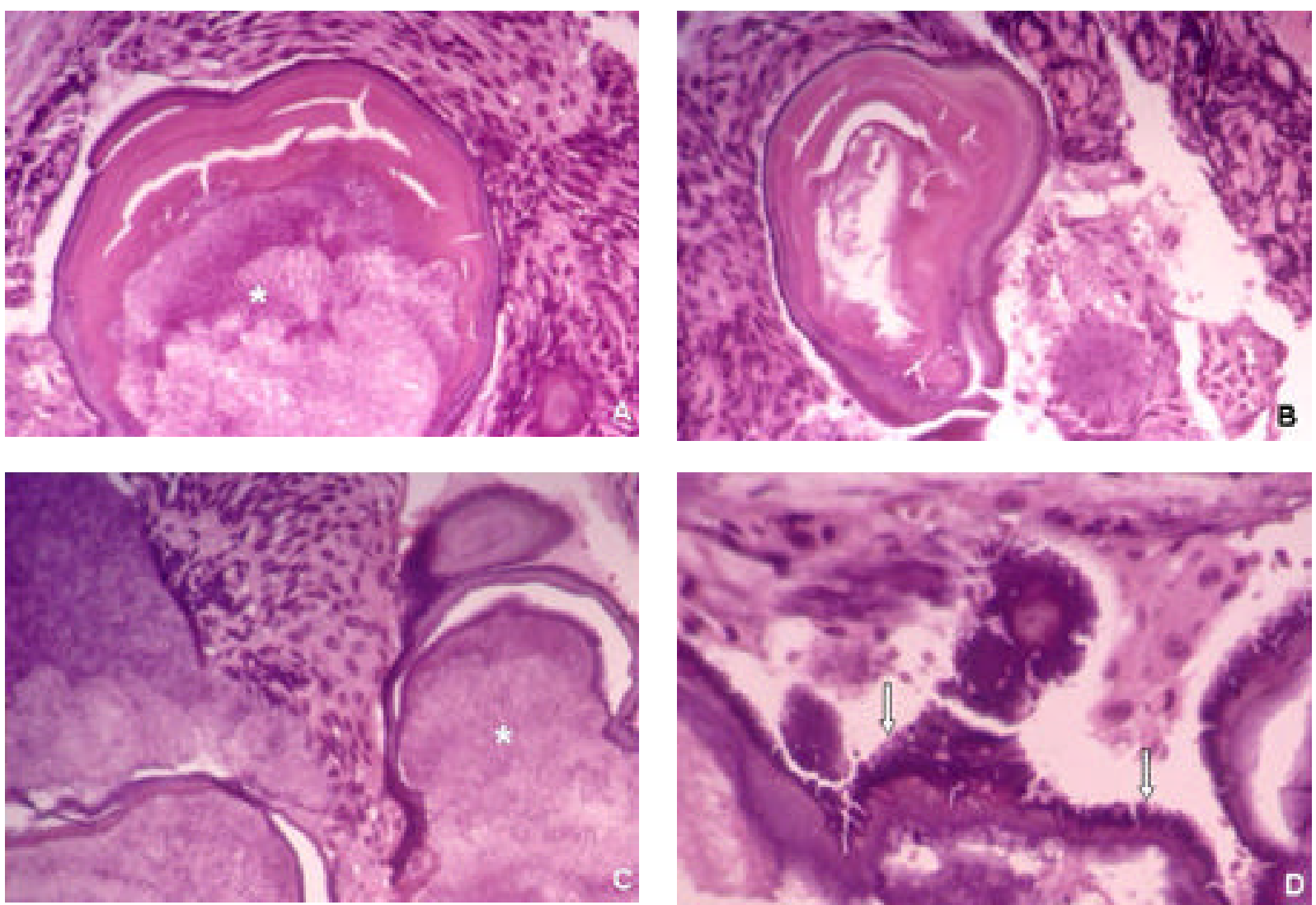

Figura 8b - Sialólitos em ducto excretor associado à rica presença de bactérias em forma de aglomerados $\left(^{*}\right)$ e biofilmes microbianos (setas). Destaca-se a forma concêntrica de deposição das camadas dos sialólitos e sua íntima associação com os aglomerados bacterianos, alguns tipo actinomices"like" e biofilmes microbianos (H.E.; aumento original: $A=100 X$; $B=100 X$; $C=100 X ; D=160 X$ ) 

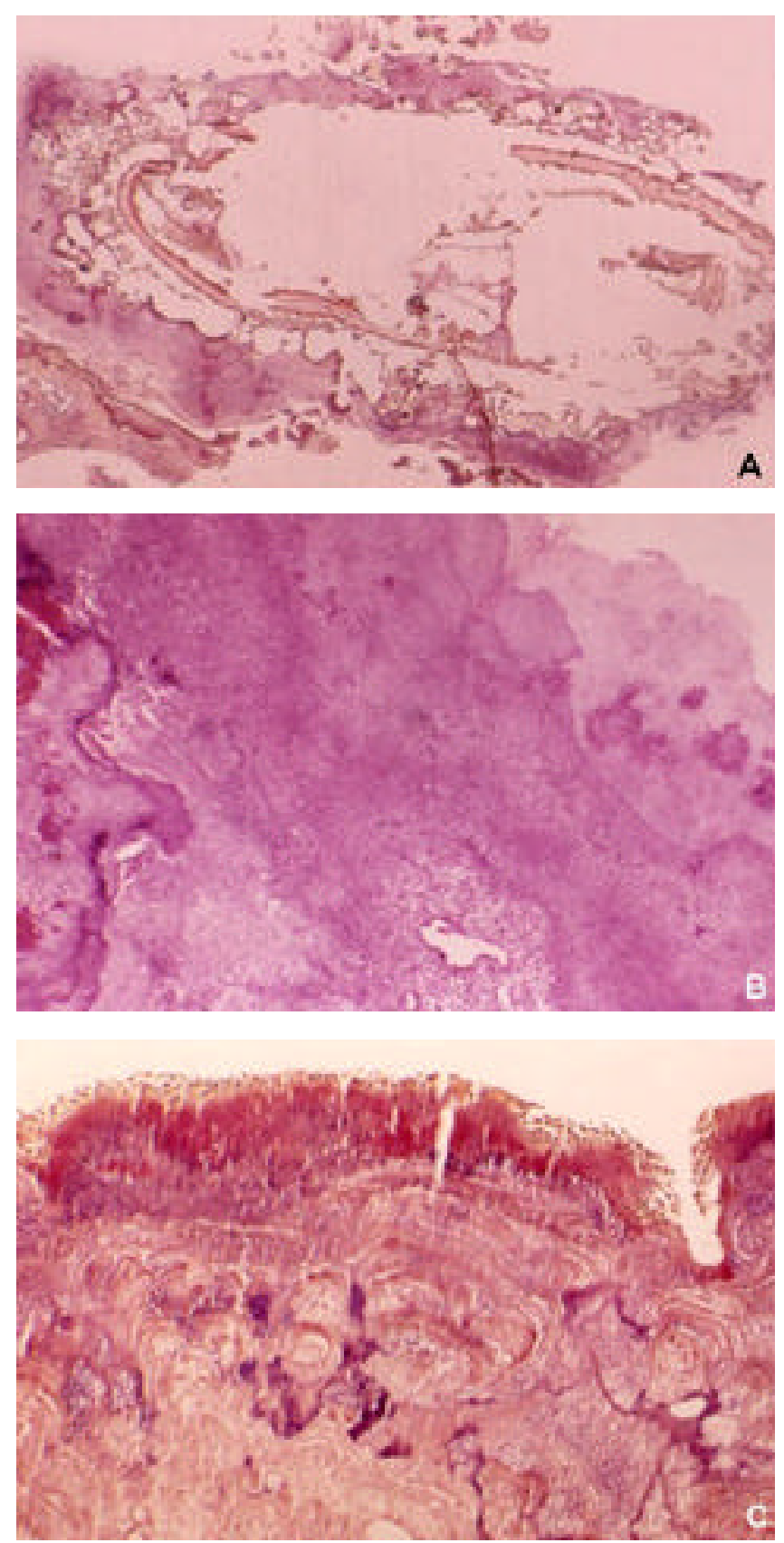

Figura 9 - Sialólito revelando a formação de anéis concêntricos de mineralização com aglomerados bacterianos e biofilmes microbianos entre suas camadas de aposição. Nos aglomerados bacterianos notam-se bactérias Gram-positivas e Gram-negativas, (B.B.; aumento original: $A=10 X ; B=40 X ; C=40 X)$ 

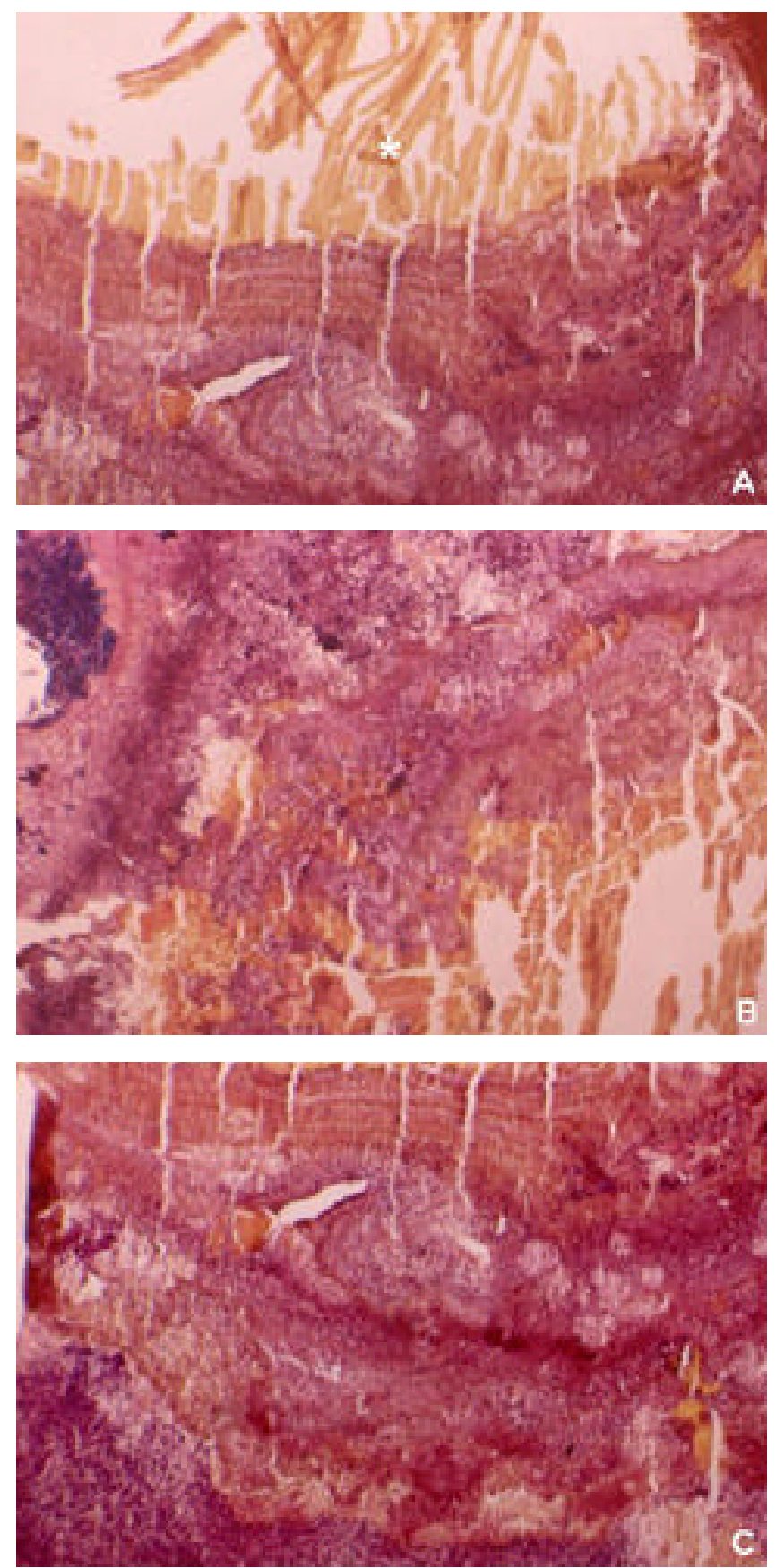

Figura 10 - Aspectos microbianos observados nos sialólitos sob a coloração de Brown e Brenn. Destaca-se a presença de locais com abundantes bactérias Gram-positivas (em azul) e Gram-negativas (em vermelho). De permeio nota-se também aspectos peculiares das camadas mineralizadas do sialólito $\left(^{*}\right)$, (B.B.; aumento original: $A=40 X ; B=40 X$; $C=40 X$ ) 

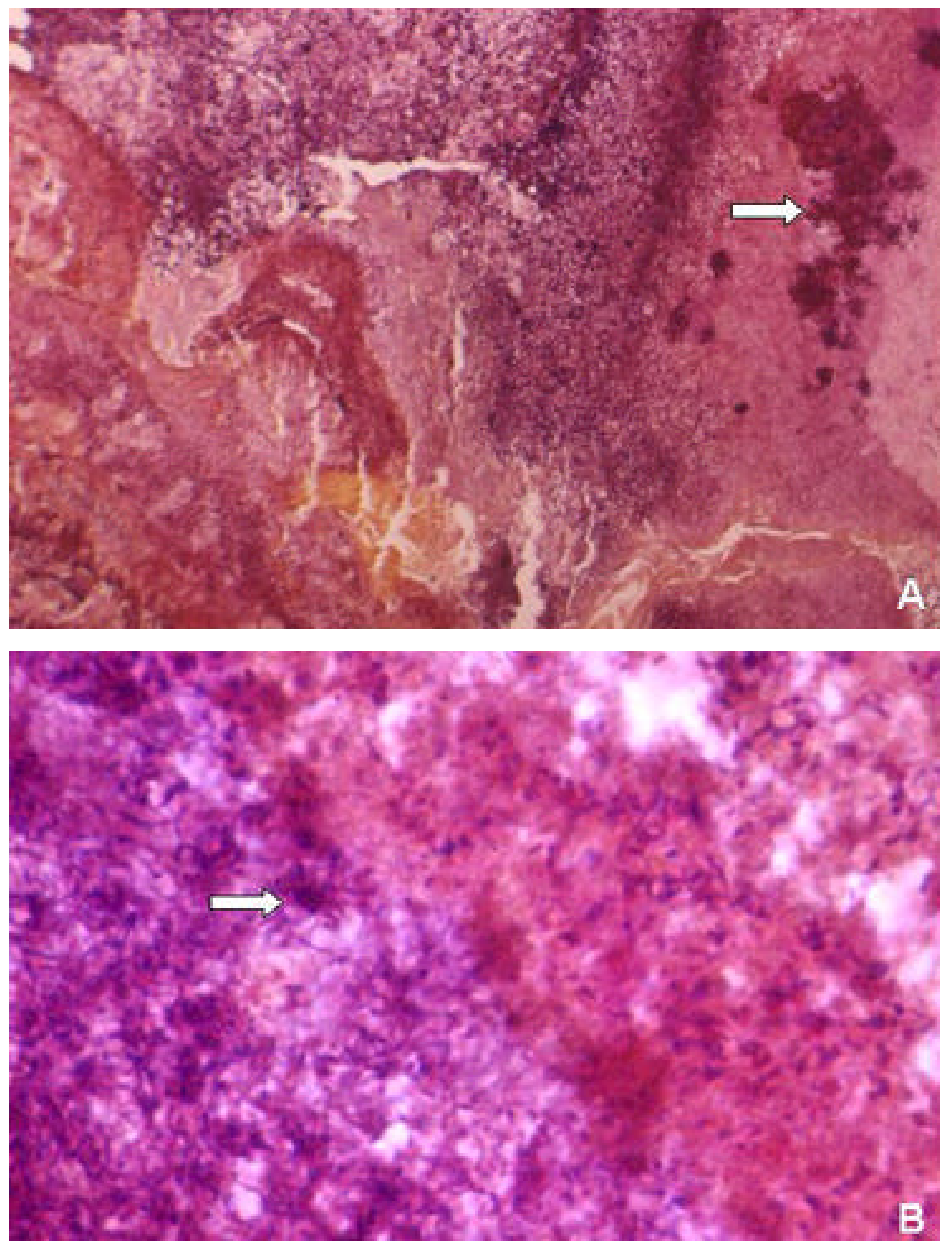

Figura 11 - Aspectos microbianos observados nos sialólitos sob a coloração de Brown e Brenn. Destaca-se a presença de locais com abundantes bactérias Gram-positivas (em azul) e Gram-negativas (em vermelho). Nota-se ainda morfologias diferentes de alguns aglomerados (setas) e de algumas bactérias como evidentes bacilos e espirilos, (B.B.; aumento original: $A=40 X ; B=100 X)$ 

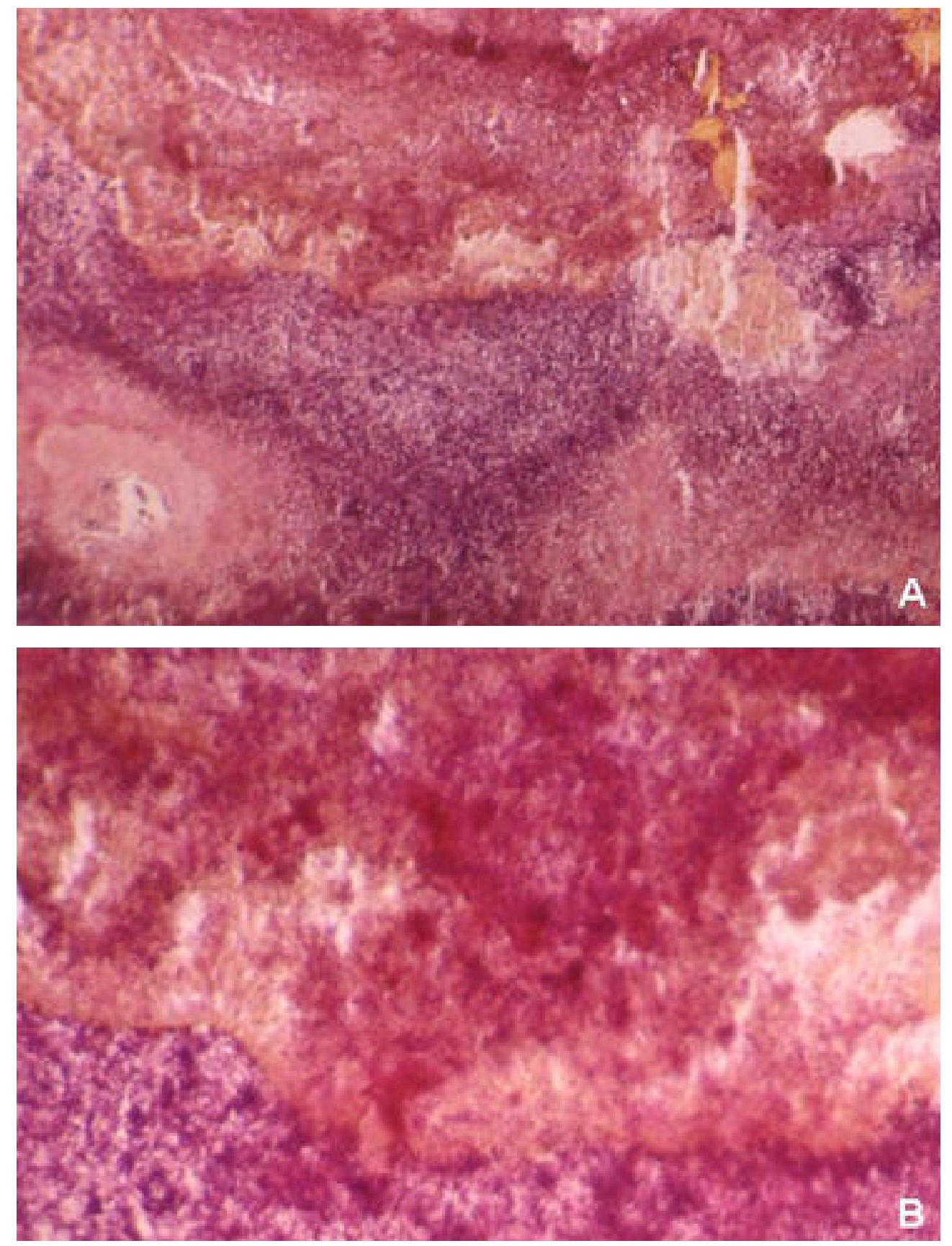

Figura 12 - Aspectos microbianos observados nos sialólitos sob a coloração de Brown e Brenn. Destaca-se a presença de locais com abundantes bactérias Gram-positivas (em azul) e Gram-negativas (em vermelho), (B.B.; aumento original: $A=40 X ; B=160 X$ ) 

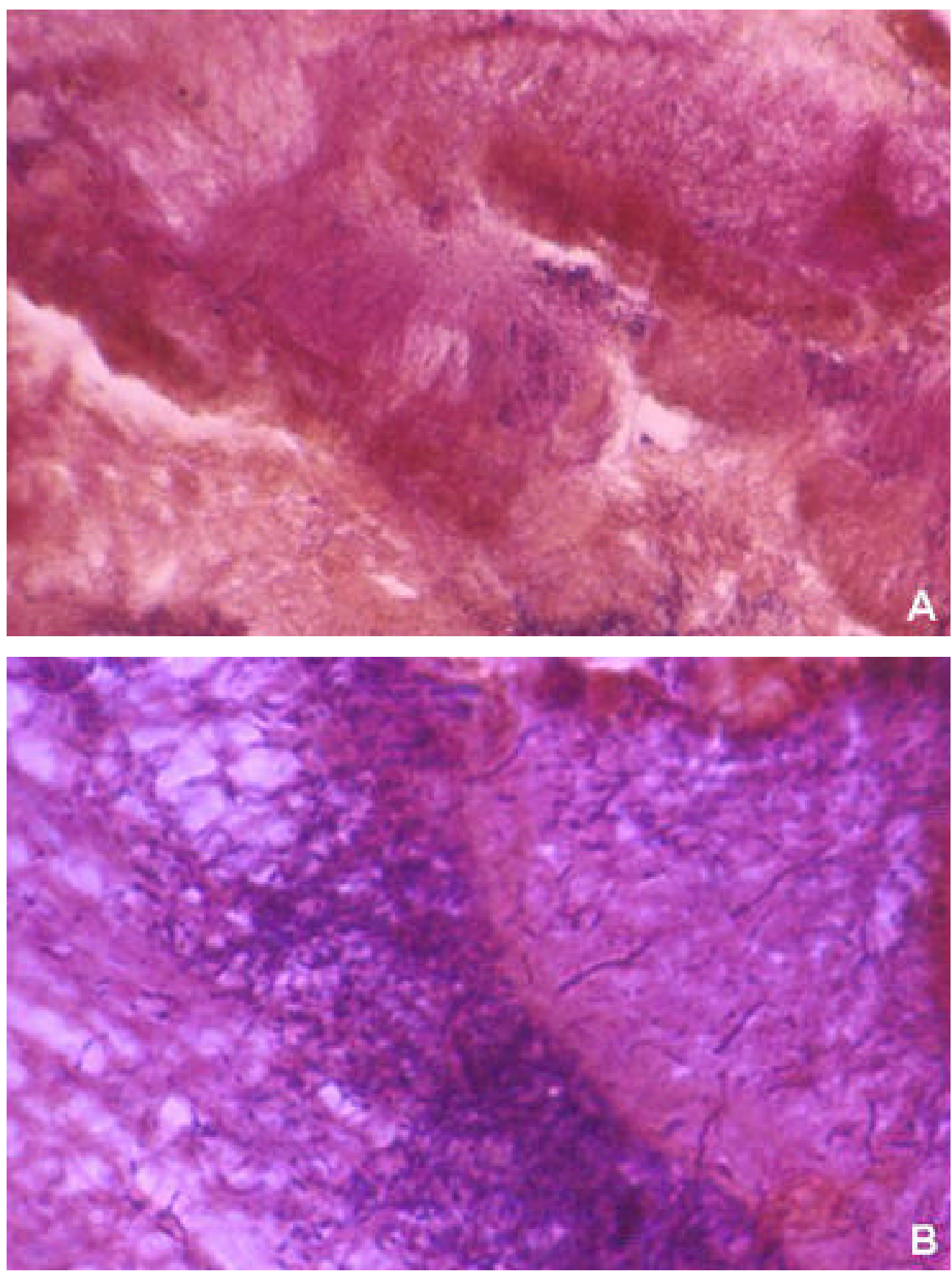

Figura 13 - Aspectos microbianos observados nos sialólitos sob a coloração de Brown e Brenn. Destaca-se a presença de locais com bactérias Grampositivas (em azul) e Gram-negativas (em vermelho). Observa-se grande quantidade de espirilos e bacilos, (B.B.; aumento original: $A=400 X ; B=400 X$ ) 


\subsubsection{Ao microscópio de luz polarizada:}

Quanto à distribuição dos cristais os sialólitos revelaram-se com organização em seis padrões: linear, puntiforme, radiado, mosaico, homogêneo e misto. Em cada padrão procurou-se uma associação morfológica que melhor descrevesse o aspecto observado.

Em cinco casos $(33,3 \%)$ o padrão de mineralização foi linear, a refração dos cristais formava estruturas lineares concêntricas, ao redor de um núcleo, descrevendo formações semelhantes a "cascas de cebola" (Figura 14). Em um espécime $(6,6 \%)$ as camadas assemelhavam-se a "ondas" ou "rajadas de vento", em outros dois $(13,3 \%)$ essas ondas se entrelaçavam ora concêntricas, ora paralelas, conferindo um aspecto de várias estruturas sobrepostas (Figura 15).

O padrão puntiforme ou focal ou, ainda, globular foi observado em dois casos (13,3\%). Nesse padrão, a refração dos cristais formava inúmeros pontos, ora aleatoriamente dispostos conferindo aspecto de "céu estrelado", ora organizados perifericamente como um "colar de diamantes", ou ainda em grupos, geralmente periféricos, dando aspecto globular à estrutura, as Figuras 16 e 17 evidenciam esse padrão.

Em um único espécime (6,6\%) observou-se um padrão radiado, nesse caso os cristais refratavam a luz polarizada como "raios de sol"; havia mais de um núcleo de mineralização no mesmo espécime, e, em todos, o padrão de organização repetiu-se (Figura 18). 
Em dois casos (13,3\%) a refração observada formava mosaicos superpostos. Nesses casos os cristais apresentavam forma bem definida, ora alongada e rombóide, ora alongada com ângulos vivos, mostrando superfícies maiores que as observadas no padrão puntiforme ou focal (Figura 19).

Dois casos $(13,3 \%)$ revelaram refração homogênea à luz polarizada onde os cristais conferiam aspecto de "trama de tecido" ao espécime, não se via nenhuma figura reconhecível, apenas um emaranhado de partículas apresentando refração (Figura 20).

Em três casos (20\%), considerados mistos, não foi possível identificar um único padrão de refração dos cristais, as estruturas mostravam-se com padrões associados ora lineares, ora globulares, com áreas de refração puntiforme ou de mosaico (Figura 21).

Nos espécimes onde havia presença de tecido mole $(26,6 \%)$ notourse alguma refração puntiforme e difusa de permeio ao conjuntivo, ao que nomeamos de puntiforme estromal (Figura 22).

Em um espécime, observourse a refração dos cristais concentrada no interior de ductos, de maneira puntiforme, porém, densamente organizada, onde interpretamos como sendo um micrólito intraductal de organização homogênea (Figura 23).

Na coloração de H.E., à luz polarizada, se viam padrões puntiformes e em mosaico, o que confirmava as observações feitas quando o sialólito era observado em luz polarizada, sem coloração (Figura 24). Nos casos onde havia presença de tecido glandular notourse refração puntiforme tanto na luz dos ductos dilatados da glândula como entre o sialólito e o ducto envolvido na sialolitíase, nestes casos, conferindo aspecto de "céu estrelado" à região envolvida (Figura 25). 
Quando os padrões puntiforme (13,3\%), radiado $(6,6 \%)$, mosaico $(13,3 \%)$ e misto (20\%) eram observados havia presença de birrefringência ${ }^{9}$; quando eram os padrões linear $(33,3 \%)$ e homogêneo $(13,3 \%)$ a serem observados havia presença de refração ${ }^{91}$ apenas. Nos espécimes que apresentavam tecido mole, independentemente do padrão de organização do sialólito, observourse birrefringência de permeio ao tecido.

Entre os 11 espécimes desmineralizados (73,3\% da amostra) apenas seis (54,5\%, n=11) apresentavam birrefringência; dos quatro espécimes não desmineralizados $(26,6 \%$ da amostra) apenas dois $(50 \%, n=4)$ mostravam birrefringência. 
Tabela 4 - Registro dos achados microscópicos referentes aos cortes sem coloração, examinados ao microscópio de luz polarizada

\begin{tabular}{|c|c|c|c|c|c|c|c|c|c|c|c|c|c|c|c|c|c|c|c|c|}
\hline \multicolumn{4}{|c|}{ ESPÉCIME } & 1 & 2 & 3 & 4 & 5 & 6 & 7 & 8 & 9 & 10 & 11 & 12 & 13 & 14 & 15 & $\mathbf{T}$ & $\%$ \\
\hline \multirow{10}{*}{ 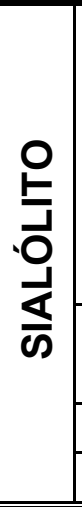 } & \multirow{6}{*}{\multicolumn{2}{|c|}{$\begin{array}{l}\text { Distribuição dos } \\
\text { cristais }\end{array}$}} & Linear & & & & $\mathrm{x}$ & & & $\mathrm{x}$ & & & $\mathrm{x}$ & & & & $x$ & $\mathrm{x}$ & 5 & 33,3 \\
\hline & & & Puntiforme & & & & & $\mathrm{x}$ & & & & & & $\mathrm{x}$ & & & & & 2 & 13,3 \\
\hline & & & Radiado & & & & & & & & $x$ & & & & & & & & 1 & 6,6 \\
\hline & & & Mosaico & & & & & & $\mathrm{x}$ & & & & & & & $\mathrm{x}$ & & & 2 & 13,3 \\
\hline & & & Homogêneo & & $x$ & $x$ & & & & & & & & & & & & & 2 & 13,3 \\
\hline & & & Misto & $x$ & & & & & & & & $x$ & & & $\mathrm{x}$ & & & & 3 & 20,0 \\
\hline & \multirow{2}{*}{\multicolumn{2}{|c|}{ Tipo de imagem }} & Refração & $\mathrm{x}$ & $x$ & $\mathrm{x}$ & $x$ & & & $x$ & & $x$ & $x$ & & $x$ & & $\mathrm{x}$ & $x$ & 10 & 66,6 \\
\hline & & & Birrefringência & $x$ & & & & $\mathrm{x}$ & $x$ & & $\mathrm{x}$ & $x$ & & $x$ & $x$ & $x$ & & & 8 & 53,3 \\
\hline & \multicolumn{3}{|c|}{ Espécime desmineralizado } & $x$ & $\mathrm{x}$ & $x$ & $\mathrm{x}$ & $\mathrm{x}$ & & $x$ & $x$ & $x$ & & $\mathrm{x}$ & $\mathrm{x}$ & & & $\bar{x}$ & 11 & 73,3 \\
\hline & \multicolumn{3}{|c|}{ Espécime não desmineralizado } & & & & & & $x$ & & & & $x$ & & & $x$ & $x$ & & 4 & 26,6 \\
\hline \multirow{7}{*}{ 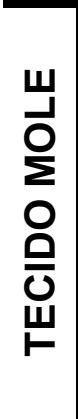 } & \multirow{6}{*}{ 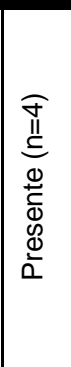 } & \multirow{4}{*}{ Localização } & Epitélio & & & & & & & & & & & & & & & & - & - \\
\hline & & & $\begin{array}{c}\text { Tecido } \\
\text { conjuntivo }\end{array}$ & & & & & & $\bar{x}$ & & $\mathrm{x}$ & & & $x$ & & & & & 3 & 75,0 \\
\hline & & & $\begin{array}{l}\text { Parênquima } \\
\text { glandular }\end{array}$ & & & & & & $x$ & & $\mathrm{x}$ & & $\mathrm{x}$ & $\mathrm{x}$ & & & & & 4 & 100,0 \\
\hline & & & Ductos & & & & & & $\mathrm{x}$ & & $\mathrm{x}$ & & $x$ & $x$ & & & & & 4 & 100,0 \\
\hline & & \multirow{2}{*}{$\begin{array}{l}\text { Tipo de } \\
\text { imagem }\end{array}$} & Refração & & & & & & & & & & & & & & & & - & - \\
\hline & & & \begin{tabular}{|l} 
Birrefringência \\
\end{tabular} & & & & & & $\mathrm{x}$ & & $\mathrm{x}$ & & $x$ & $\mathrm{x}$ & & & & & 4 & 100,0 \\
\hline & \multicolumn{3}{|c|}{ Ausente $(n=15)$} & $x$ & $x$ & $x$ & $x$ & $x$ & & $x$ & & $x$ & & & $x$ & $x$ & $x$ & $x$ & 11 & 73,3 \\
\hline
\end{tabular}



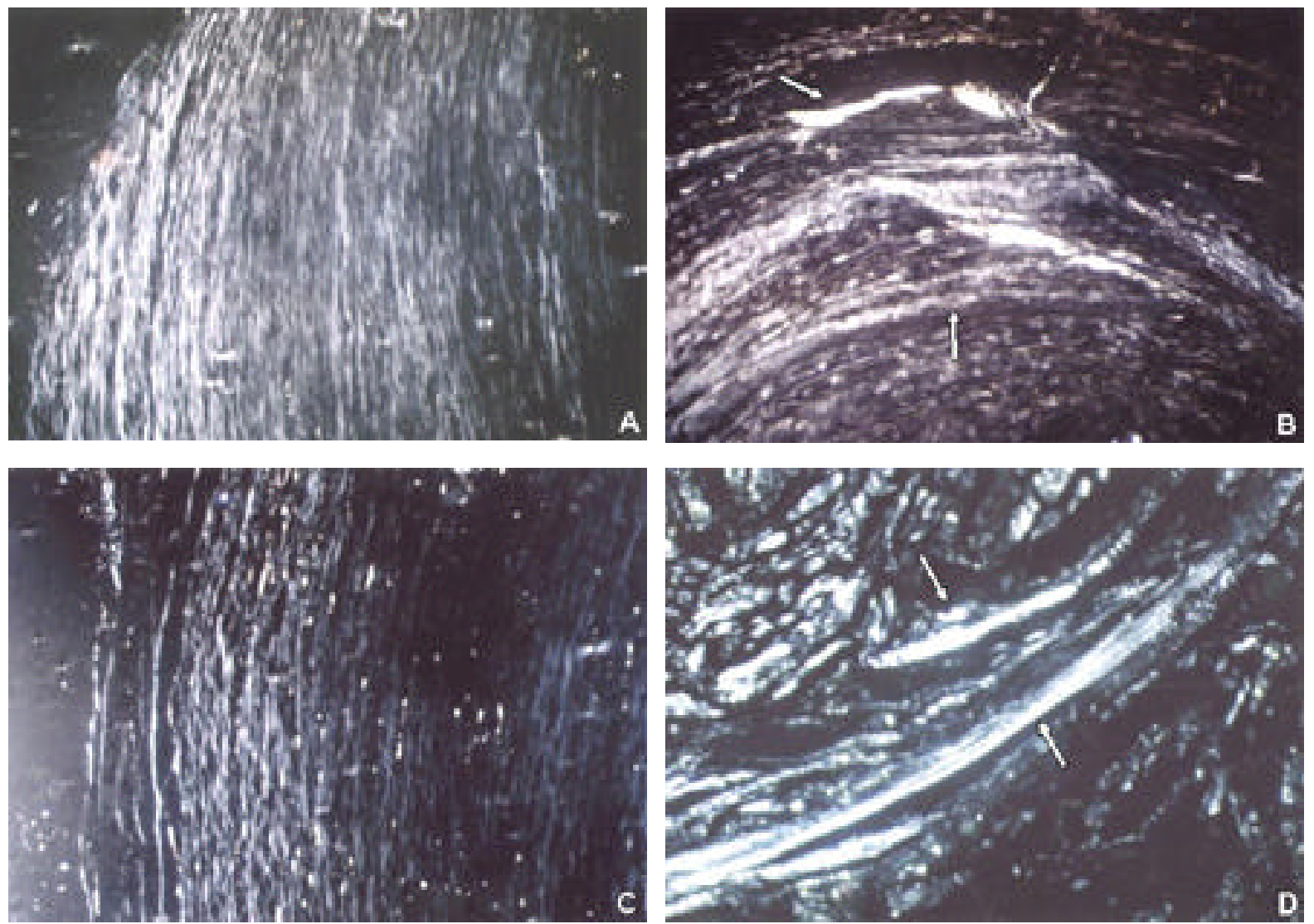

Figura 14 - À luz polarizada, o padrão dominante de mineralização observado nos sialólitos foi o linear, descrevendo camadas concêntricas com áreas de evidente densidade (setas), (aumento original: $A=12 X ; B=50 X ; C=12 X$; $D=100 X)$ 

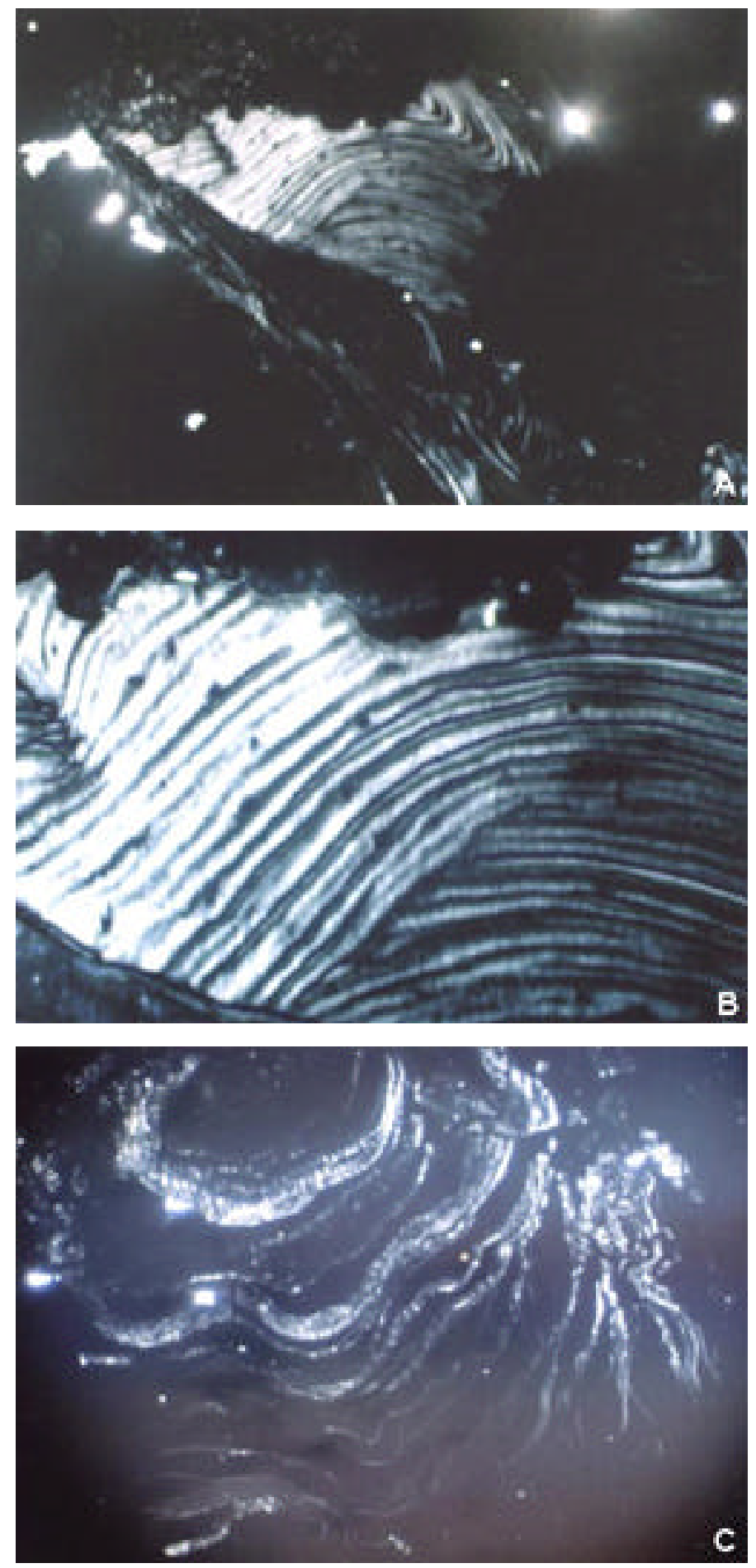

Figura 15 - O padrão de organização linear mostrou algumas variações: em um espécime as camadas estavam entrelaçadas ( $A$ e $B$ ), em outro assemelhando-se a "ondas" ou "rajadas de vento" (C), (aumento original: $A=12 X ; B=50 X ; C=12 X)$ 

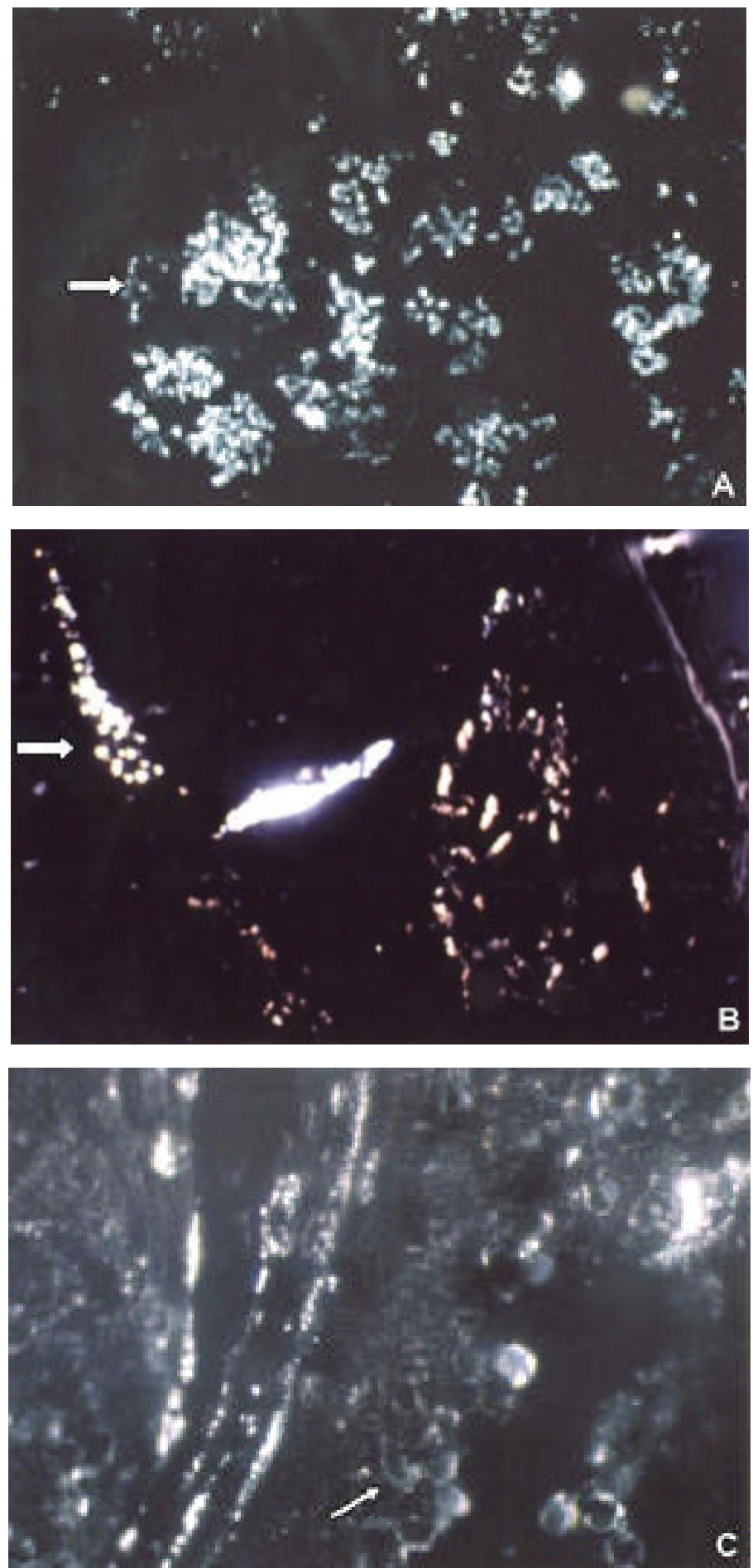

Figura 16- Padrão puntiforme ou focal. Observam-se inúmeros pontos ora aleatoriamente dispostos, ora organizados em grupos (setas), (aumento original: $A=50 X ; B=12 X ; C=50 X$ ) 


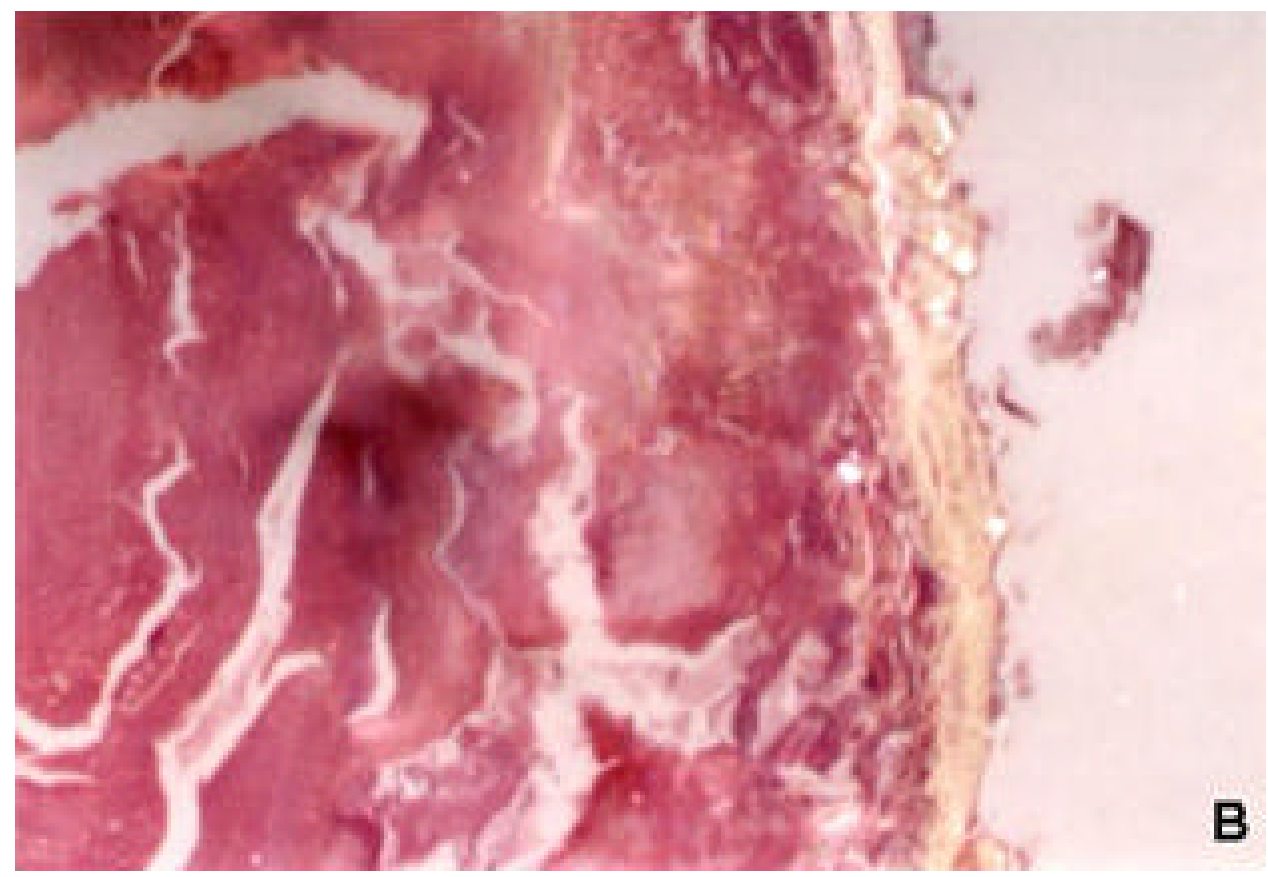

Figura 17 - Em um caso observou-se 0 padrão puntiforme organizado perifericamente como um "colar de diamantes" (A), o que confirmourse quando observamos o espécime corado em hematoxilina-eosina de Harris (H.E.) por meio de luz polarizada (B), (aumento original: $A=12 X$; $B=50 X)$ 

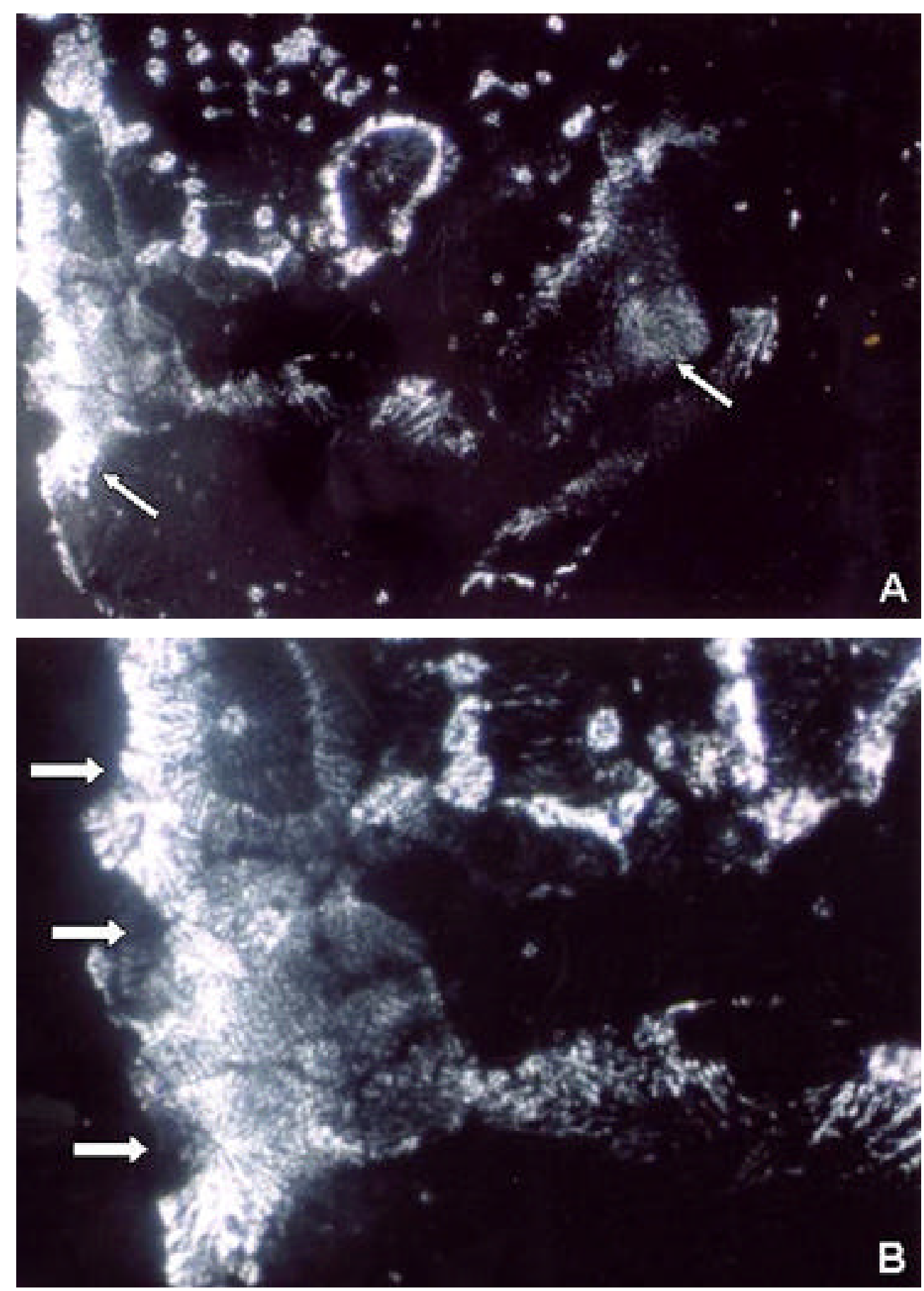

Figura 18 - Vários núcleos de mineralização foram observados em um espécime que mostrou padrão radiado de organização (setas), (aumento original: $A=12 X ; B=50 X)$ 

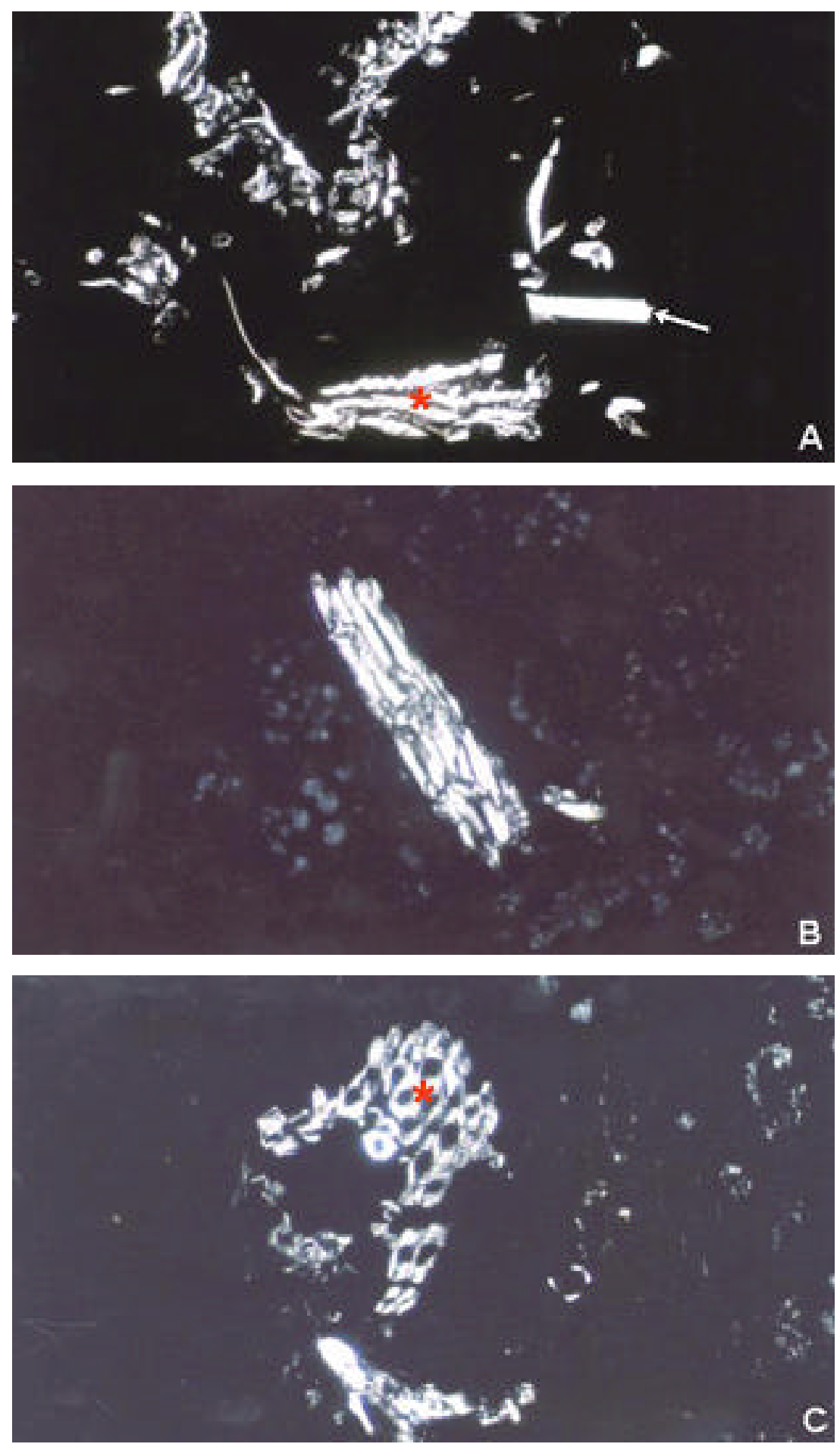

Figura 19 - Dois espécimes refratavam a luz polarizada formando mosaicos $\left({ }^{*}\right)$, alguns cristais apresentavam-se com ângulos vivos (seta), (aumento original: $A=100 X ; B=100 X ; C=160 X)$ 


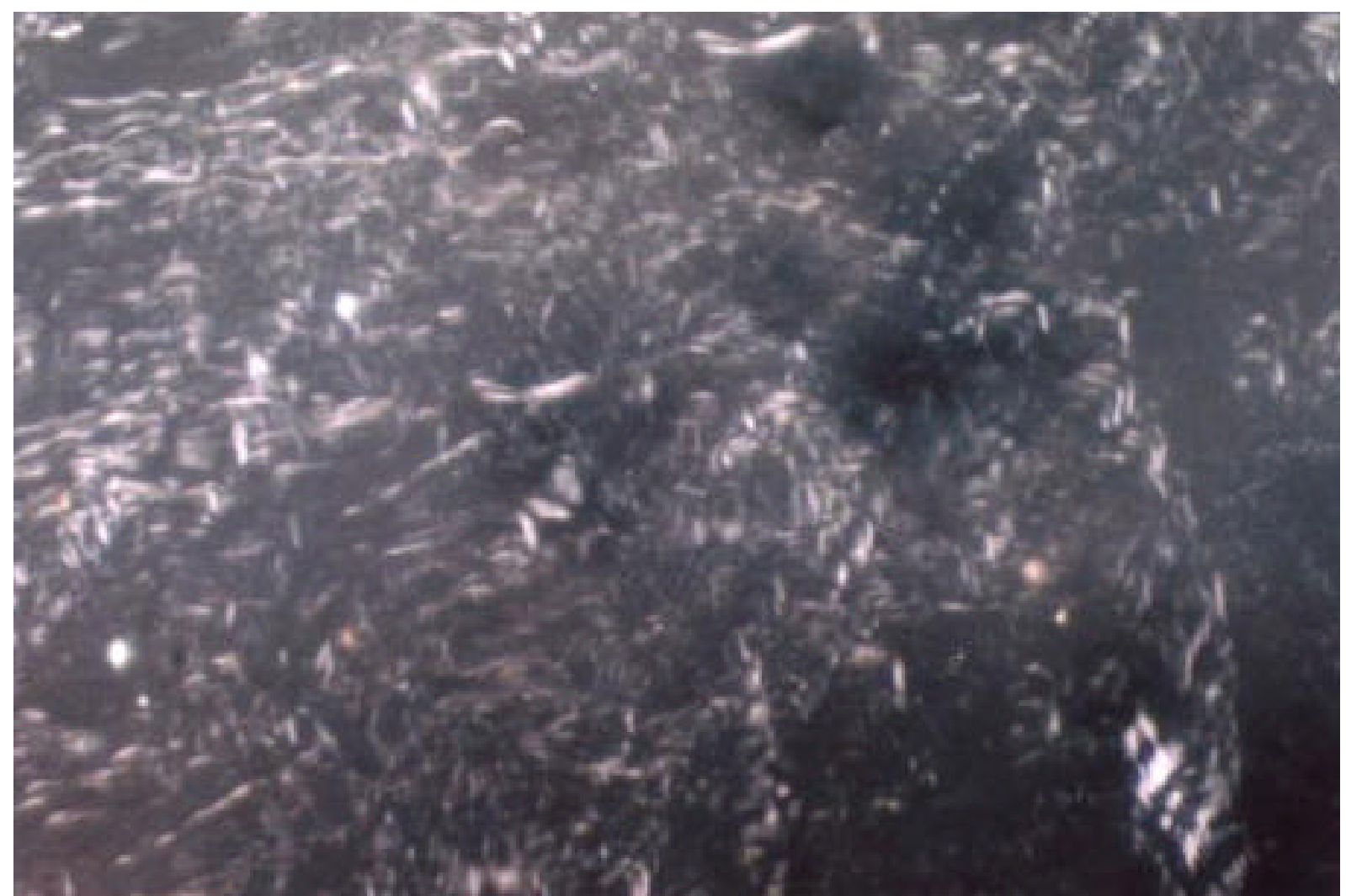

Figura 20 - Padrão homogêneo à luz polarizada. Nota-se aspecto de "trama de tecido", aumento original $100 \mathrm{X}$ 

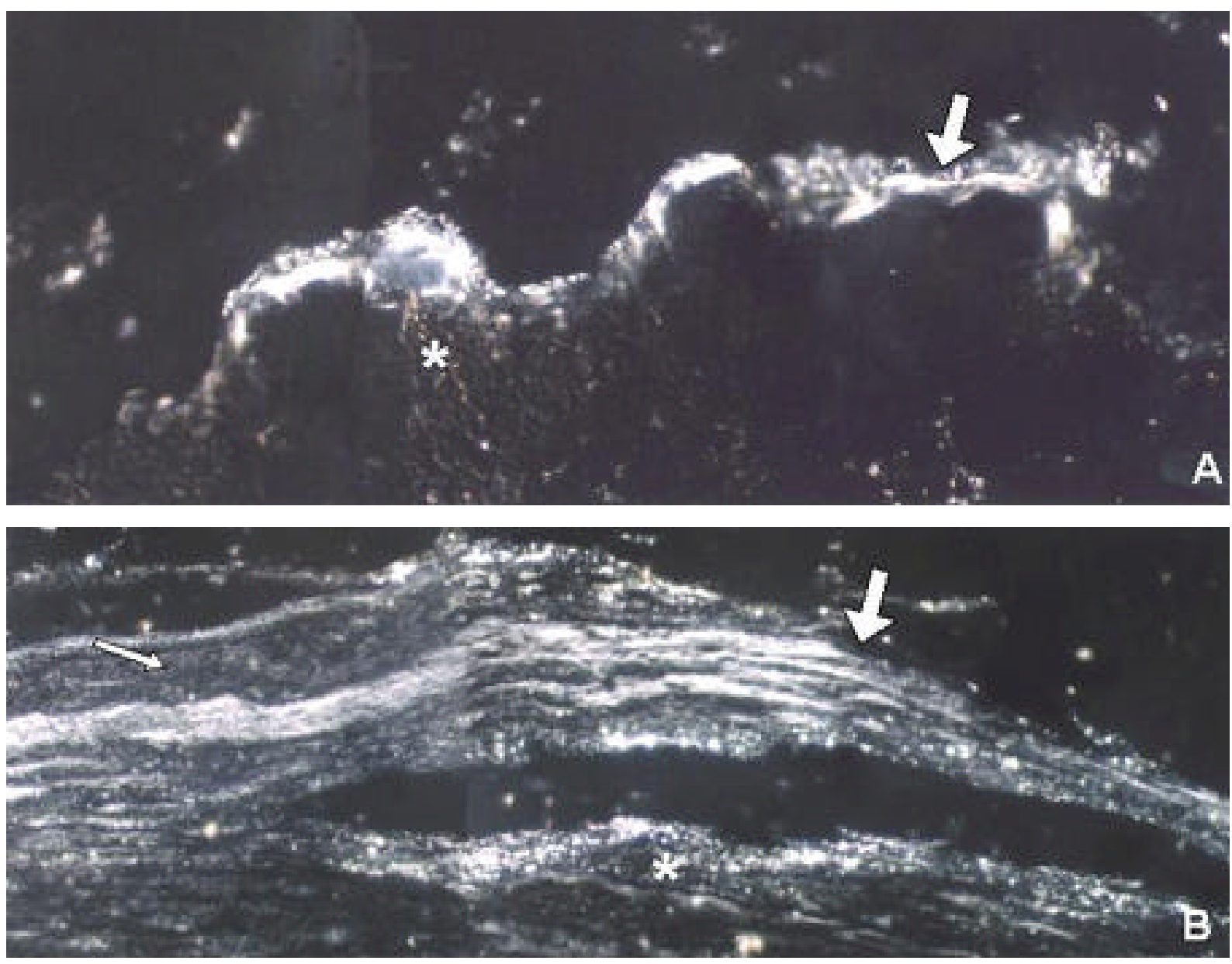

Figura 21 - Em três casos não havia um único padrão predominante de organização quando os espécimes eram observados à luz polarizada, considerados por este motivo como padrão misto. Áreas de padrão puntiforme $\left(^{*}\right)$, linear (seta maior) e homogêneo (seta menor), (aumento original: $A=50 X ; B=100 X)$ 

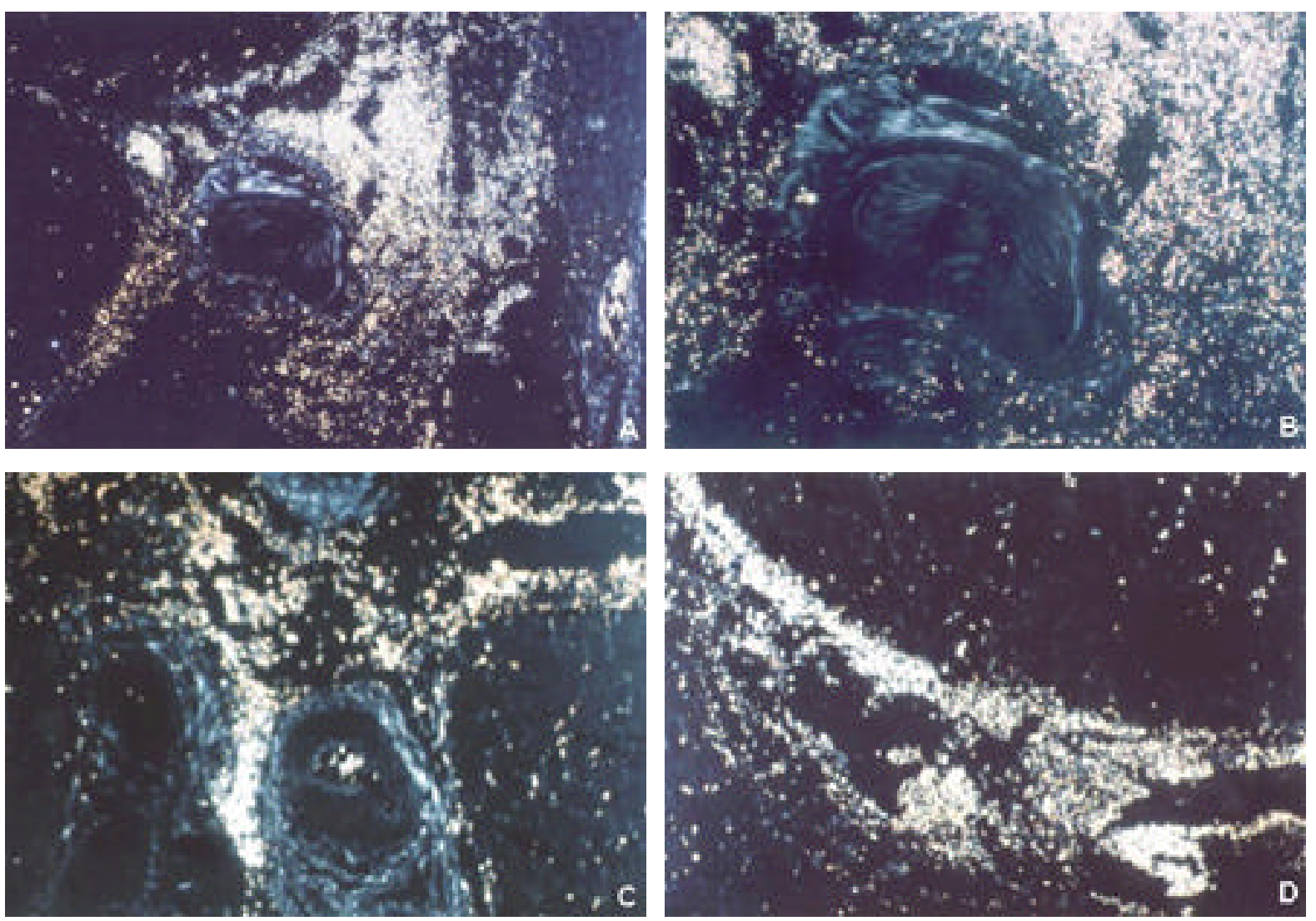

Figura 22 - Nos espécimes que apresentavam tecido mole notou-se a presença de refração puntiforme, difusa, de permeio ao conjuntivo, ao que nomeamos de puntiforme estromal, (aumento original: $A=50 X ; B=100 X$; $C=50 X ; D=50 X)$ 

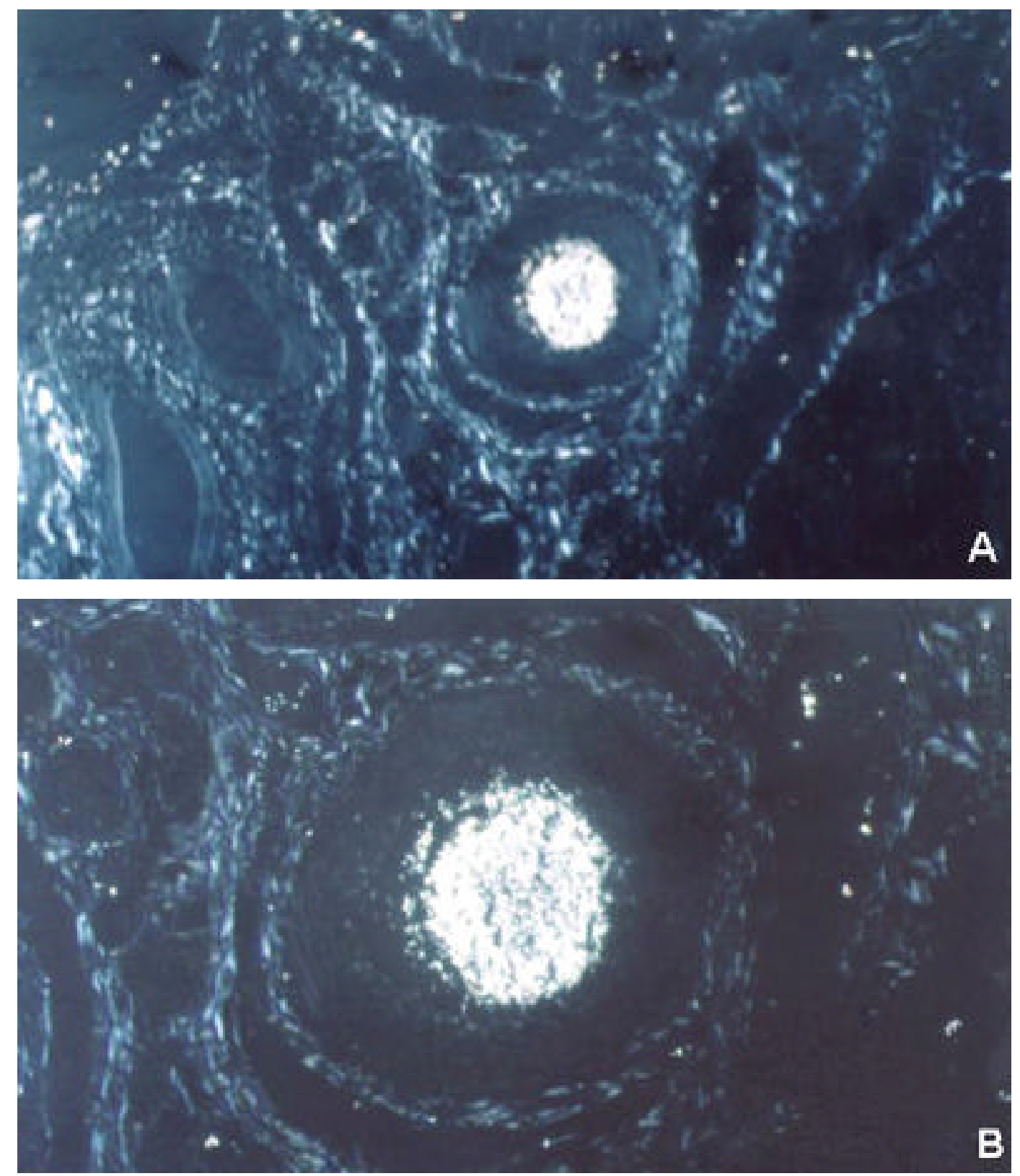

Figura 23 - Refração puntiforme, densamente organizada, constituindo um micrólito intraductal (aumento original: $A=100 X ; B=160 X$ ) 

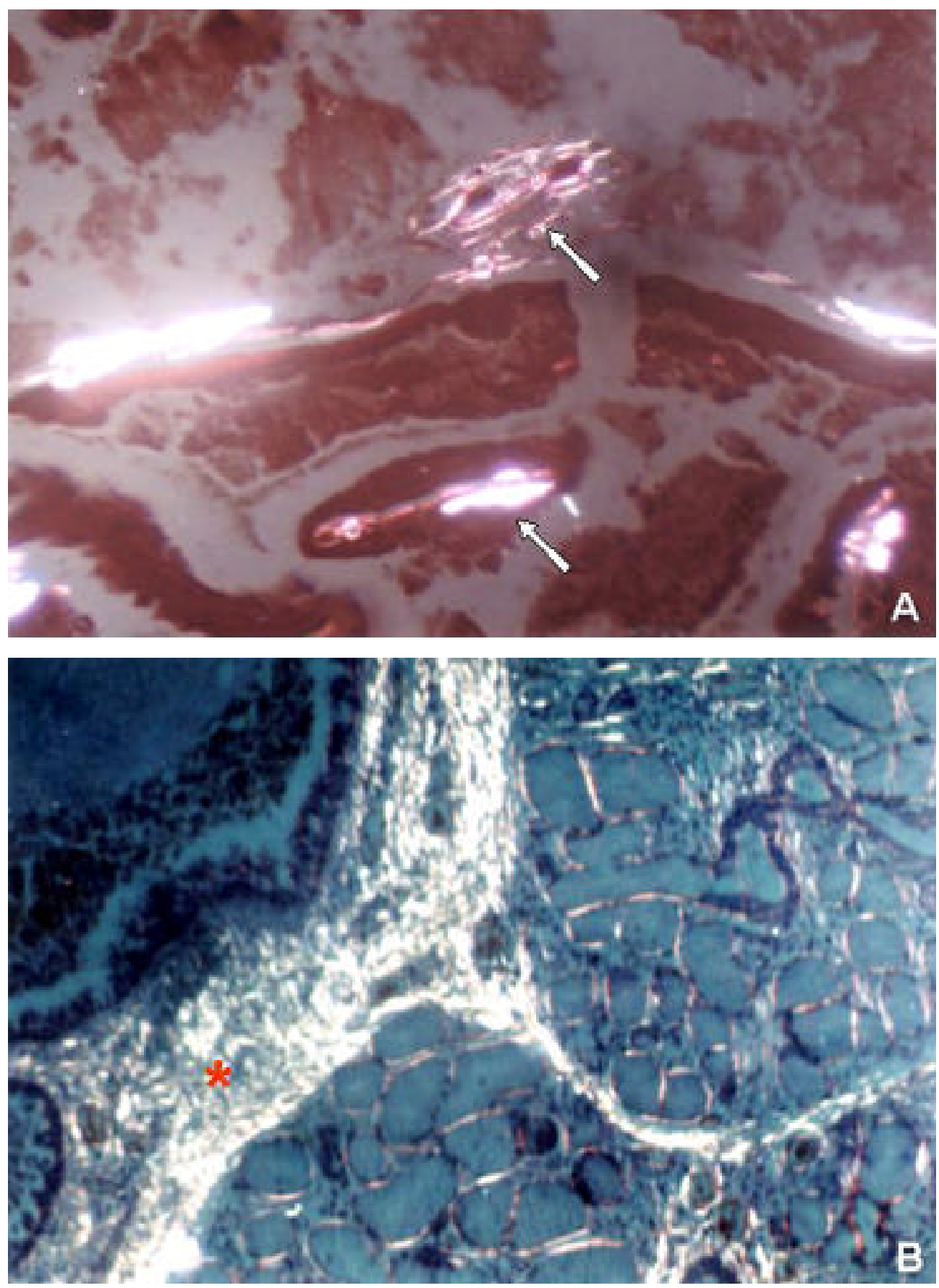

Figura 24 - Algumas lâminas coradas pela hematoxilina-eosina de Harris (H.E.) foram observadas à luz polarizada. Notaram-se padrões puntiforme $\left(^{*}\right) \mathrm{e}$ em mosaico (setas), confirmando as observações feitas à luz polarizada pela técnica original, (aumento original: $A=50 X ; B=160 X$ ) 

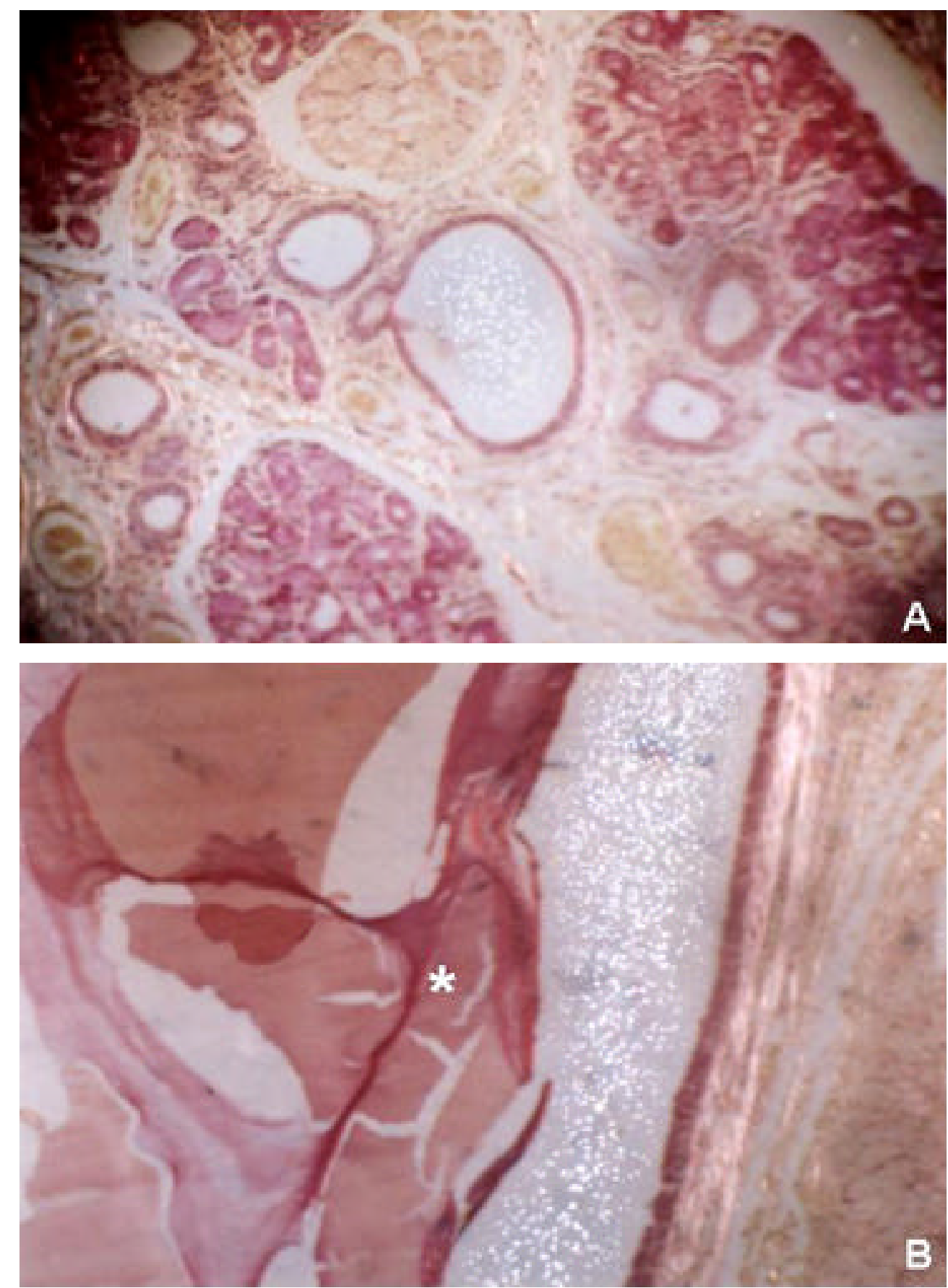

Figura 25 - Refração puntiforme presente na luz dos ductos glandulares dilatados e também entre o sialólito $\left({ }^{*}\right)$ e o epitélio ductal, conferindo aspecto de "céu estrelado" à região (aumento original: $A=50 X ; B=100 X$ ) 


\subsection{ANÁLISE ESTATÍSTICA:}

Os resultados obtidos na análise microscópica foram organizados em tabelas com dados de freqüências absolutas e relativas.

Após 21 dias, as análises foram repetidas para aplicação do índice Kappa ${ }^{64}$, utilizado para avaliação quanto ao nível de concordância de um mesmo observador, de acordo com a figura abaixo:

\begin{tabular}{|cc|}
\hline Coeficiente Kappa & Nível de concordância \\
$<0,00$ & Baixo \\
$0,00-0,20$ & Médio \\
$0,21-0,40$ & Moderado \\
$0,41-0,60$ & Substancial \\
$0,61-0,80$ & Quase perfeito \\
$0,81-1,00$ & .
\end{tabular}

Priorizaram-se os seguintes aspectos, considerados relevantes:

a) Padrão de mineralização em hematoxilina-eosina de Harris (H.E.):

Para esse critério o índice Kappa ${ }^{64}$ resultou em 0,85 , sendo o nível de concordância classificado como "quase perfeito"; 
b) Classificação quanto à morfologia das bactérias agregadas, na coloração de Brown e Brenn (B.B.):

Para esse critério o índice Kappa ${ }^{64}$ resultou em 0,76 , com nível de concordância classificado como "substancial";

c) Distribuição dos cristais nos padrões estabelecidos, em microscopia de luz polarizada:

Para esse critério o índice Kappa ${ }^{64}$ resultou em 1,00, sendo o nível de concordância classificado como "quase perfeito";

d) Tipo de imagem observado dentro dos padrões estabelecidos: refração ou birrefringência:

Para esse critério o índice Kappa ${ }^{64}$ resultou em 0,89, sendo o nível de concordância classificado como "quase perfeito". 
6 DISCUSSÃO 


\section{DISCUSSÃO}

\subsection{DA CONCEPÇÃO DO TRABALHO:}

A partir de uma reunião de checagem diagnóstica, procedimento de rotina do Serviço de Anatomia Patológica da Faculdade de Odontologia de Bauru, FOBUSP, algumas dúvidas foram surgindo com relação à morfologia e evidenciação de estruturas cristalóides que se observava em um espécime de sialólito. Com o objetivo de esclarecimento e por sugestão do Professor Doutor Alberto Consolaro iniciouse a pesquisa, com o intuito de apenas sanar aquelas dúvidas.

Sabe-se que a microscopia de luz polarizada permite a pesquisa e a determinação das anisotropias ópticas (birrefringência e dicroísmo) em tecidos biológi$\cos ^{121,123}$.

Da literatura pertinente extraíram-se apenas quatro trabalhos que utilizavam a microscopia de luz polarizada para estudo dos sialólitos ${ }^{10,63,115,121}$. Enqua nto no microscópio óptico comum e à microscopia eletrônica a morfologia dessas estruturas foi amplamente discutida e bem definida $2,5,6,10,31,40,41,43,56,58,76,77,95,100,114-117,122$, observourse uma lacuna com relação ao estudo dos sialólitos por meio de luz polarizada bem como à etiopatogenia dessas lesões, o que, nos dias atuais, ainda não está completamente esclarecida ${ }^{120}$.

O que parecia apenas resolver uma curiosidade transformourse em um dos objetivos principais deste trabalho. 


\subsection{DA METODOLOGIA EMPREGADA:}

Vários trabalhos com diferentes metodologias têm sido realizados a fim de caracterizar a estrutura dos sialólitos ${ }^{1-6,10,19,27,40,43,51-56,58,63,70,76,95,100,114-117,121,122 . ~}$

Muitas casuísticas têm sido descritas e caracterizadas em detalhes tanto em aspectos clínicos quanto microscópicos $22,23,42,53,56,58,63,66,67,69,81,86,89,105,107,125$.

Para avaliação da morfologia, sob vários aspectos, as colorações que poderiam ter sido utilizadas neste estudo são: Hematoxilina-eosina de Harris, coloração básica para morfologia; Azul alciano, os sialólitos coram-se em vermelho-alaranjado claro com pontos bem definidos em azul; von Kossa evidencia estruturas que contenham material mineralizado, em marrom escuro; Ácido periódico de Schiff (PAS) cora estruturas ricas em polissacarídeos como glicogênio e mucopolissacarídeos de células mucosas, bem como tecido conjuntivo; Azul de toluidina, que confere uma cor homogênea azul à matriz orgânica com pequenas áreas purpúreas; preto do Sudão indica a presença de lipídios na matriz orgânica; vermelho Congo evidencia birrefringência; Azul da Prússia, utilizado para evidenciar a presença de espiroquetas; Mucicarmim, ta mbém chamado corante de Mayer, para coloração de fungos; Orcein para evidenciação de fibras elásticas; van Gieson, evidenciador de substância colágena; Reação de Millon, que evidencia proteínas e Brown e Brenn, para evidenciação de bactérias.

Dois dos principais objetivos de nosso estudo eram a evidenciação de bactérias e a observação de estruturas cristalóides. Alguns blocos da nossa amostra apresentavam material escasso, dessa maneira não poderíamos correr o risco de 
algum espécime não fazer parte de alguma das análises. Alguns trabaIhos $^{32,40,52,115,116}$ que utilizaram as colorações PAS, azul da Prússia, azul alciano, mucicarmim, orcein, van Gieson, vermelho Congo e reação de Millon não obtiveram resultados satisfatórios para a evidenciação de cristalóides, porém os sialólitos coraram-se intensamente com hematoxilina-eosina de Harris e von Kossa. A maioria dos trabalhos que objetivou a evidenciação de bactérias, teve bons resultados utilizando a coloração de Brown e Brenn $2,3,5,12,13,58,94$.

Optamos por uma coloração que nos fornecesse subsídios para um estudo geral (hematoxilina-eosina de Harris), outra que evidenciasse as bactérias (Brown e Brenn) e outros cortes que nos permitissem a observação de cristais por meio da microscopia de polarização, nesse caso sem coloração. Dessa maneira bdos os espécimes participaram de todas as análises.

A escolha da análise microscópica óptica inicial pelo método mais utilizado: hematoxilina-eosina de Harris, deveurse ao fato de que estaríamos discutindo morfologia e essa coloração serve de suporte para qualquer estudo. Com essa técnica podemos também observar colônias e biofilmes microbianos, porém a detecção precisa de bactérias em tecidos não é possível pela H.E., especialmente quando individualizadas e distribuídas na forma planctônica.

A técnica mais utilizada para detecção de morfotipos bacterianos é a de Gram modificado para tecidos incluídos em parafina a partir dos trabalhos de Brown; Brenn $^{17}$, sendo conhecida atualmente como técnica de coloração de Brown e Brenn $^{17,18,119}$ e utilizada em vários estudos $2,3,5,12,13,58,94$; esta técnica de coloração permite visualizar a distribuição das bactérias na forma planctônica, em colônias, em biofilmes microbianos e no interior de células inflamatórias. Além de várias formas de organização bacteriana, ela permite também detectá-las de permeio às várias por- 
ções dos sialólitos. As bactérias Gram-positivas coram-se em azul ou roxo e as Gram-negativas coram-se em vermelho claro; os núcleos celulares coram-se em vermelho ou rosa intenso e outros elementos teciduais, como o citoplasma celular, coram-se em amarelo.

Apenas quatro trabalhos utilizaram microscopia de luz polarizada no estudo dos sialólitos. O primeiro, em 1958, de BLATT et al. $^{10}$, usou a microscopia de polarização apenas como complemento para a técnica de difração de raios $\mathrm{x}$ em pulverização, não citando detalhes quanto aos resultados das observações feitas pela microscopia de polarização. Em 1986, TAKEDA ${ }^{115}$ após submeter cortes dos espécimes a várias colorações fez suas considerações e, com relação à microscopia de luz polarizada, apenas citou que aqueles sialólitos não apresentavam birrefringência $^{9}$.

LAFORGIA et al. ${ }^{63}$, em 1989, realizaram análise morfológica e microestrutural em 56 sialólitos e por meio da microscopia de luz polarizada evidenciaram a distribuição das áreas que continham substância mineralizada nos espécimes.

Em 2001, TRAINI et al. ${ }^{121}$ analisaram um único sialólito de glândula submandibular utilizando os microscópios eletrônico e óptico de luz polarizada, revelando a detecção de birrefringência ${ }^{9}$ no espécime.

Devido às dúvidas surgidas a partir dessas publicações como, por exemplo: quais são os diferentes padrões de mineralização que podemos observar ou se a distribuição dos cristais, observada pela luz polarizada, mostra contornos semeIhantes aos observados em H.E., optamos por utilizar a microscopia de luz polarizada para completar e auxiliar a caracterização microscópica da nossa amostra. 


\subsection{DOS RESULTADOS OBTIDOS:}

Na caracterização da amostra houve discreta predominância do gênero feminino, o que diverge dos resultados apresentados em algumas casuísti$\operatorname{cas}^{5,22,42,46,53,56,63,66,89,118}$ e concorda com outros autores ${ }^{58,69}$. Essa maior prevalê ncia do gênero feminino não nos parece significante, podendo ser comparada aos resultados obtidos pelo segundo grupo de autores já que os resultados são baseados em relatos clínicos, muitas vezes apresentando dados incompletos.

Quanto à idade, a amostra observada foi acorde com outras casuísticas $^{5,42,56,58,66,69,89,118}$ em que a população afetada pela sialolitíase encontrou-se numa faixa etária adulta, ocorrendo apenas um caso em criança, este, na literatura tido como raro $46,63,69,107$.

O grupo de glândulas salivares mais afetadas, as submandibulares, também foi compatível com as observações feitas em outros trabalhos já publica$\operatorname{dos}^{10,46,63,66,69,86}$ e o acometimento dos outros grupos de glândulas salivares, proporcionalmente, também coincidiu.

A história clínica pobremente apresentada, muitas vezes inexistente, confere dificuldade para caracterização da amostra neste quesito. Seria audacioso, senão pouco científico, discutirmos sobre dados tão incompletos. Tomemos como exemplo o tempo de evolução das lesões: variando de alguns meses a 20 anos, poderíamos concluir, precipitada e equivocadamente, como sendo tempo de ampla variação; não podemos esquecer que dos 15 espécimes apenas quatro apresentavam essa informação, ou seja, aproximadamente $26,6 \%$ de informação não seriam suficientes para emissão de qualquer comentário relativo também aos outros $73,3 \%$ da amostra, podendo os extremos de tempo (6 meses e 20 anos) ser exceção. 
O mesmo ocorreu com relação aos relatos radiográficos onde apenas um caso trazia informações a respeito. Essa falta de história clínica poderia sugerir que sialolitíase, quando sendo uma das sugestões diagnósticas do clínico, não é associada a nenhuma maior anormalidade sistêmica, sendo, portanto, tratada apenas bcalmente.

Os sialólitos não têm estrutura uniforme, sua morfologia varia extensivamente não apenas no mesmo espécime como de um espécime para outro, independentemente se advindos das glândulas salivares maiores ou das glândulas salivares menores ${ }^{1}$

Alguns sialólitos mostram estrutura lamelar, com exceção da porção central ou núcleo que se mostra homogênea, com camadas alternadas basofílicas e eosinofílicas, onde as áreas mineralizadas são basofílicas e as áreas não mineralizadas eosinofílicas, na coloração de hematoxilina-eosina de Harris (Figura 1).

Alguns sialólitos não apresentam o padrão lamelar periférico conferindo uma figura homogeneamente arranjada e em alguns casos de organização mista (Figura 5), sem predomínio de um único padrão (lamelar ou homogêneo), onde a configuração torna-se de difícil delimitação, pois as áreas com lamelas ficam de permeio às homogêneas. Quando estão bem distintas apresentam-se mais delgadas e perifericamente distribuídas, nesse caso, a área homogênea toma por volta de dois quartos do raio do sialólito, enquanto a área lamelar ocupa um quarto e outro é ocupado pelo núcleo.

Nos espécimes que apresentavam tecido mole $(26,6 \%$ da amostra), em alguns pontos, havia contato direto entre o cálculo salivar e o epitélio ductal, em outros havia presença de biofilmes e agregados bacterianos entre as duas estruturas (Figuras 8). Esse contato pode representar a contribuição necessária para que tanto 
os elementos das células descamadas quanto o infiltrado inflamatório cheguem à matriz orgânica do cálculo salivar. Nesse caso, haveria o que poderia ser chamado de retroalimentação, ou seja, as bactérias e suas toxinas oriundas da superfície do cálculo salivar atrairiam o infiltrado inflamatório que, juntamente com os remanescentes das células descamadas do epitélio ductal e os elementos locais, iriam auxiliar na formação de mais matriz orgânica, que iria atrair mais bactérias e assim sucessivamente.

As alterações microscópicas observadas nos tecidos e ductos pericalculares como dilatação, infiltrado inflamatório e alterações do epitélio de revestimento do ducto com metaplasia escamosa, oncocítica ou mucosa representam as reações teciduais como resultado da completa ou parcial obstrução ductal. A ocorrência de metaplasia escamosa geralmente está associada tanto à infecção local quanto à agressão de contato do sialólito com o epitélio ductal ${ }^{1,72}$; quando tratamos de metaplasia oncocítica ocorre a proliferação de células com citoplasma eosinofílico rico em mitocôndrias, às vezes claro e rico em glicogênio; a metaplasia mucosa conseqüente aos mesmos fatores apresenta a proliferação de células caliciformes, produtoras de muco.

No tecido glandular remanescente, circunvizinho ao cálculo salivar, também observamos alterações teciduais como infiltrado inflamatório crônico difusamente distribuído, atrofia acinar e fibrose, geralmente associados ao tempo de evolução da obstrução (Figura 6).

Na coloração de H.E., o padrão lamelar de organização em alguns casos foi de difícil interpretação visto o espécime estar fragmentado; nesses casos, quando da classificação quanto ao número de centros de mineralização, optourse por observação panorâmica, em menor aumento, onde projetávamos espacialmente a circun- 
ferência de um fragmento, seguindo sua sugestão de angulação, tentando encaixálo nos demais e assim sucessivamente; quando essas correlações não puderam ser conseguidas e a projeção formava mais de uma circunferência, os espécimes foram considerados com mais de um centro de mineralização. Essa dificuldade pode ter acarretado algum erro de interpretação, o que foi confirmado na aplicação do índice Kappa ${ }^{64}$, pois algum espécime com mineralização unicêntrica de padrão misto de organização, pode ter sido equivocadamente classificado como multicêntrico, para essa coloração, em alguma das análises.

O processamento dos tecidos, isto é, fixação, desmineralização, inclusão em parafina e microtomia, pode provocar a perda de bactérias ou de sua capacidade tintorial $^{12,13,94}$. Os agentes químicos empregados nas desmineralizações de tecidos duros interferem na atividade tintorial de células bacterianas Gram-positivas. As alterações mais significantes foram observadas com o ácido fórmico a 5\%, empregado por uma semana, quando se constatou que em cada 15 bactérias, somente uma corava-se de azul; os melhores resultados foram obtidos quando se empregou o ácido etilenodiaminotetracético (EDTA) a 5\% na desmineralização dos espécimes, resultando em cortes onde as bactérias apresentavam-se sem alterações morfológicas significantes $^{94}$

A desmineralização dos espécimes que foram submetidos ao procedimento foi realizada alguns com ácido fórmico a 5\%, outros com EDTA. Detectou-se pela coloração de Brown e Brenn tanto bactérias Gram-positivas quanto Gram-negativas em todos os espécimes.

As bactérias Gram-positivas contêm mucopeptídio e ácido teicóico fazendo parte da parede celular, o que pode induzir reações inflamatórias granulomatosas com a participação dos linfócitos T e dos macrófagos; além disso, podem ativar o 
complemento e agem como estimuladores policlonais dos linfócitos B. As bactérias Gram-negativas possuem lipopolissacarídios ou endotoxinas fazendo parte da parede celular e participam na indução do processo inflamatório e ativação do complemento ${ }^{13,120}$.

A maioria dos agregados e biofilmes bacterianos apresentou-se como Gram-positivos, particularmente quando foram observados na periferia dos espécimês (Figuras 11 e 12) . Como a maioria dos autores ${ }^{1,2,3,5,54,70,77}$ não relatou a presença de bactérias no núcleo e em suas lamelas vizinhas, causournos surpresa detectá-las nesses sítios em três espécimes: em um apenas no núcleo e em outros dois nas lamelas próximas ao núcleo. Pressupomos que este fato deva estar relacionado ao pequeno tempo de evolução da lesão, o que não se sabe precisamente, onde as bactérias estariam na periferia e, dependendo do grau de mineralização e configuração morfológica do espécime, circunvizinhas à área observada; outra possibilidade seria que mesmo mineralizadas como um todo ou fragmentadas essas bactérias ainda estivessem mantendo sua capacidade tintorial.

Todos os espécimes foram observados pela microscopia de polarização, independentemente se previamente desmineralizados ou não. Por meio do método de desmineralização utilizado, ou quelação por difusão, alguns autores ${ }^{1,40,114}$ observaram apenas a matriz orgânica de sialólitos.

Um corpo birrefringente tem duas direções de propagação da luz com um índice de refração ${ }^{91}$ para cada uma delas. Esses materiais quando colocados entre polarizadores cruzados alteram a propagação da luz, provocando um brilho característico ${ }^{63,123}$.

As estruturas cristalóides como as observadas nos espécimes também foram identificadas por meio de técnicas como microrradiográfica, difração de pulveri- 
zação ou energia dispersiva de raios $x$, em outros estudos sobre cálculo sali$\operatorname{var}^{1,2,10,19,31,32,76,95,100,117}$.

Julgamos a comparação de resultados obtidos por meio de metodologias diferentes não ser o melhor procedimento, mas em vista dos poucos trabalhos registrados na literatura empregando a luz polarizada em sialólitos ${ }^{10,63,115,121}$, ousamos por analogia traçar algumas considerações.

A organização lamelar concêntrica descrita à microscopia óptica comum, ao microscópio eletrônico foi reconhecida como uma área extremamente concentrada em cristais; o espaço existente entre as lamelas quando observado ao microscópio óptico, correspondia a porções menos concentradas em cristais, ao microscópio eletrônico ${ }^{54}$. Os cristais estavam, em muitos casos aleatoriamente dispostos por toda extensão da matriz orgânica. Em alguns pontos pequenos aglomerados de cristalização foram observados, organizados de forma a exibir um padrão radiado de um centro, morfologicamente idênticos às esferulitas, ou calcosferitas, freqüentemente observadas em tecidos mineralizados $2,6,10,19,29,31,40,57,75-77,19,95,103,116$. Apenas um de nossos espécimes ao microscópio de luz polarizada revelou birrefringência de aparência radiada (Figura 18).

A grande variação na distribuição dos cristais em sialólitos nos indica a variação da capacidade da matriz orgânica em reter íons cálcio e fosfato. Alterações de propriedades físicas e químicas locais como concentração desses íons, variação de $\mathrm{pH}$, concentração de mucina e capacidade tampão da saliva, presentes ao redor do cálculo salivar, influenciam diretamente esse processo ${ }^{19,31,32}$. A presença de estruturas mineralizadas homogêneas ou mais compactas, como a formação em "mosaico", sugere que além dos fatores contribuintes já citados podemos incluir o fator tempo (Figura 19). 
Por meio da microscopia de luz polarizada observou-se em um espécime a presença de micrólitos intraductais, porém não havia organização lamelar, apenas um concentrado de estruturas birrefringentes desenhando um contorno relativamente esférico (Figura 23). Este espécime quando examinado ao microscópio óptico comum, em coloração de hematoxilina-eosina de Harris, não mostrava qualquer substância intraductal. Concluímos que neste caso havia mineralização inicial dos microcálculos e, nesses estádios, já que os sialólitos não apresentam radiopacidade suficiente para serem detectados em microrradiografias, poderiam igualmente não ser detectados ao microscópio óptico comum, camuflando-se de permeio ao tecido.

Microcálculos já foram identificados intracelularmente, intraluminalmente em ácinos e ductos, também intersticialmente, apresentando-se basofílicos, homogêneos ou lamelares, por meio de técnicas de coloração de rotina como hematoxilina-eosina de Harris ${ }^{32}$.

Intracelularmente os microcálculos foram observados em células acinares de glândulas salivares normais. Sabe-se que os autofagossomas estão envolvidos na digestão de grânulos secretórios armazenados. Tal degeneração desses grânulos e organelas como mitocôndrias, que podem ser ricas em cálcio e fósforo, poderia levar a uma acumulação destes elementos e sua cristalização intracelular ${ }^{32,42}$.

Mucina ácida e neutra, encontradas em micrólitos, estão presentes nos grânulos secretórios de células acinares de glândulas submandibulares, sustentando a possibilidade de grânulos secretórios degenerativos estarem envolvidos na formação dos microcálc ulos ${ }^{32,42,122}$.

Existem semelhanças morfológicas entre os cristais dos microcálculos intracelulares e aqueles que observamos nos cálculos salivares ductais; associandose essas semelhanças com a presença de cálcio e fósforo dos micrólitos intracelula- 
res, poderíamos admitir que estes também possuem cristais de apatita ${ }^{31,32,42,122}$. Tais relatos apóiam nossas observações por meio de luz polarizada, uma vez que não foram encontradas diferenças significantes entre os cristalóides de cálculos salivares observados e o padrão "puntiforme estromal" identificado nos espécimes que se apresentavam acompanhados de tecido mole (Figura 22).

Sabendo-se que a mineralização ocorre secundariamente ao longo das fibras orgânicas, o arranjo aleatório dos cristais observado em alguns casos nos leva a crer que a organização da matriz orgânica dos sialólitos, ainda que possuindo um padrão relativamente regular de deposição, nem sempre corresponderá à deposição regular do material mineral. Como a disposição lamelar dos sialólitos não é homogênea, conclui-se que em muitos casos a mineralização do cálculo salivar não ocorre de maneira cíclica como um todo e sim de forma focal, nas áreas onde as condições locais são mais favoráveis.

Alguns resultados não coincidiram, quanto ao padrão de mineralização, quando comparadas as técnicas de microscopia óptica comum e de polarização. Um espécime que apresentava organização lamelar em luz polarizada, ao microscópio óptico mostrou-se com padrão homogêneo; outro, também de padrão homogêneo ao microscópio óptico comum, apresentou-se com padrão radiado à luz polarizada. Esse desencontro de observações prova velmente deva-se ao fato de que ao microscópio de luz polarizada obtemos maior poder de resolução e observação, onde todas as estruturas cristalóides, independentemente da extensão são evidenciadas.

A observação de estruturas cristalóides nos espécimes que foram submetidos à desmineralização nos questiona sobre as imagens observadas: se as imagens conferem determinados padrões aos espécimes em luz polarizada, é sinal que ainda restam cristais de permeio à matriz orgânica dos sialólitos. Em seis espécimes 
desmineralizados (54,5\% dos espécimes desmineralizados, 40\% dos espécimes estudados) foi observada a presença de birrefringência, em outros cinco $(45,5 \%$ dos desmineralizados, $33,3 \%$ do total estudado) que sofreram o mesmo processamento observamos apenas refração.

A técnica para a microscopia de luz polarizada preconiza cortes sem coloração $^{123}$; os espécimes que apresentavam tecido mole $(26,6 \%$ da amostra) foram observados ao microscópio de polarização tanto em lâminas sem coloração, como indica a técnica original, quanto na coloração de H.E. (Figuras 17, 24 e 25). Nestes casos, alterava-se a angulação dos filtros polarizadores, permitindo a passagem de alguns feixes de luz, o que produziu imagens coradas em hematoxilina-eosina de Harris relativamente escuras, porém simultâneas à presença de birrefringência nos padrões puntiforme e mosaico, o que era confirmado quando o espécime estava submetido à técnica original da microscopia de luz polarizada, ou seja, sem coloração ${ }^{123}$.

LAFORGIA et al. ${ }^{63}$, examinando 56 sialólitos pela luz polarizada, detectaram estrutura lamelar concêntrica com periodicidade regular periférica em todos seus espécimes. Relataram a não birrefringência do núcleo dos sialólitos e a presença de espécimes com vários núcleos de mineralização; os espécimes dessa pesquisa estavam armazenados a seco, sem desmineralização prévia, e foram submetidos a um corte sagital inicial. Posteriormente uma das metades, incluída em resina, foi submetida a novos cortes de 20ìm cada e então analisada ao microscópio de luz polarizada; a outra porção foi observada em estereomicroscópio. Ainda que nossa amostra tenha sido reduzida em comparação à desses autores, também pudemos observar vários núcleos de mineralização em um mesmo espécime. Detectamos a presença de substâncias minerais reconhecíveis por sua refração ao feixe 
de luz polarizada, dispostas de seis padrões distintos. Nossos resultados divergem dos de LAFORGIA et al. ${ }^{63}$ apenas pela variedade de padrões que observamos. Comparando as ilustrações publicadas pelos autores, percebemos semelhanças com algumas das imagens que obtivemos em nossa amostra.

Sendo a análise morfológica qualitativa, optou-se pela aplicação do índice Kappa ${ }^{64}$, a fim de evidenciar a confiabilidade do método de análise utilizado e a calibração do examinador. Os critérios foram selecionados de acordo com sua relevância para os objetivos propostos neste trabalho: análise morfológica dos espécimes em microscopia de luz comum e polarizada e evidenciação de bactérias.

O nível de concordância para três dos critérios selecionados: padrão de mineralização em H.E., padrão de organização em luz polarizada e tipo de imagem (refração ou birrefringência), resultou em "quase perfeito", evidenciando que estes aspectos apresentavam-se bastante claros ao examinador. Quanto ao critério de morfologia das bactérias agregadas, o índice Kappa ${ }^{64}$ resultou em "substancial", relativamente distante do nível crítico $(0,60)$. A pequena discordância entre a primeira e a segunda análise não foi estatisticamente significante. Podemos considerar que o método de análise foi eficaz e a calibração do examinador foi satisfatória.

\subsection{DAS IMPLICAÇÕES CLÍNICAS:}

Julgamos que nossa amostra constituiu-se de apenas 15 espécimes devido à maioria dos casos de sialolitíase de glândulas salivares maiores não representar, na visão do clínico, associação com distúrbios sistêmicos, dessa maneira promovem a remoção do espécime já prematuramente diagnosticado em tomadas ra- 
diográficas e exame local de rotina e não atentam ao envio da peça para análise microscópica. Quando o acometimento é nas glândulas salivares menores, o envio da peça para análise é mais freqüente, porém a incidência da lesão neste grupo de glândulas salivares é muito menor ${ }^{5,44,58,72,82,89,95}$, o que confirma os resultados.

A localização das glândulas salivares submandibulares ${ }^{42,43,66,81,118,125}$ como ocorrência da maioria dos casos de sialólitos bem como nas glândulas salivares menores do lábio superior e mucosa juga $\mathrm{P}^{5,22,25,44,46,58,72,89}$, sugerem que os fatores locais como trauma e morfologia do sistema ductal possam estar envolvidos na etiologia das sialolitíases.

A sialadenite crônica submandibular foi definida primeiramente por KÜTT$\mathrm{NER}^{62}$, em 1896, quando observando uma associação com sialolitíase, descreveu como sendo um tumor inflamatório da glândula submandibular. A importância desse trabalho é que a partir daí o termo "tumor de Küttner" passou a ser largamente utilizado para designar sialadenite crônica da glândula submandibular, particularmente na literatura alemã, o que de acordo com a atual classificação da Organização Mundial de Saúde $(W H O)$, deve ser evitado e substituído pela terminologia correta de "sialadenite crônica".

O principal fator etiológico na sialadenite crônica da glândula submandibular é o cálculo salivar ${ }^{42,53,56,105}$. O achado de micrólitos intracelulares revela que um processo de sialadenite crônica possivelmente seja secundário à formação deles, ainda que sejam microscópicos ${ }^{31,32,42}$, particularmente pelo motivo que com a idade crescente a presença desses micrólitos em glândulas salivares normais é aumenta$\mathrm{da}^{32,42}$.

Mineralizações nas glândulas salivares podem ser detectadas também em infecções crônicas, flebites, linfonodos, amiloidose e lesões tumorais, como adenoma 
pleomórfico, schwanoma e carcinoma mucoepidermóide ${ }^{90}$. Nas glândulas salivares parótidas $40 \%$ dos cálculos, independentemente da origem, são radiolucentes, detectáveis apenas com métodos como sialografia, tomografia computadorizada ou ressonância magnética. Nas glândulas salivares submandibulares esse número cai para aproximadamente $20 \%$. Devemos considerar a maior incidência de cálculo salivar nas glândulas submandibulares com relação às parótidas na proporção de 15 para 1, aproximadamente $^{19}$.

A presença de bactérias como fator etiológico das salolitíases tem sido objeto de muitas discussões ${ }^{70,73,105,120}$. ISACSSON; FRISKOPP ${ }^{54}$, em 1984, utilizando microscopia eletrônica de varredura para estudo de dez sialólitos, evidenciaram a presença de bactérias em sua periferia e, após análise, concluíram que os microorganismos podem contribuir como um importante fator para a formação da matriz orgânica do cálculo salivar, porém apenas nas fases posteriores e não nas iniciais, o que diverge da opinião de LUSTMANN; $\operatorname{SHTEYER}^{70}$ que sugerem que os microorganismos tenham importante papel tanto na formação quanto no crescimento do cálculo salivar.

TEYMOORTASH et al. ${ }^{120}$ estudando nove sialólitos obtidos a partir de sialadenites crônicas de glândulas submandibulares, analisaram a presença de microrganismos por meio de métodos de extração do DNA obtido dos fragmentos bacterianos dos cálculos salivares. A espécie predominante detectada foi Streptococcus species. Foi identificada a presença de bactérias em todos os espécimes. Concluíram que a presença de micrólitos ou a obstrução de ductos não podem ser classificadas como causa isolada da formação de sialólitos, existindo fatores adicionais necessários, onde, provavelmente, os microorganismos exerçam importante papel.

Em nossa amostra também observamos bactérias em todos os espécimes. 
Nossos resultados nos levam a concordar com ambos os grupos de autores considerando a influência que esses microorganismos e seus produtos possam exercer nos tecidos vizinhos. O que não nos parece esclarecido é que sem um núcleo inicial as bactérias não poderiam autonomamente produzir um substrato e a matriz do sialólitos ter início; dessa maneira, concordando com ISACSSON; FRISKOPP ${ }^{54}$, a invasão bacteriana viria após a formação do núcleo do cálculo salivar . Como explicaríamos a presença de DNA bacteriano no núcleo inicial como encontrado por TEYMOORTASH et al. ${ }^{120}$ ? Provavelmente o núcleo inicial seria colonizado pelos microorganismos e, a partir de então, as bactérias estariam colaborando para a formação da matriz orgânica dos cálculos salivares. Tomando-se um tempo longo de evolução, proporcionalmente os restos bacterianos envolvidos pela mineralização estariam mais próximos do núcleo, se comparados à deposição das lamelas subseqüentes de mineralização. Essa explicação nos parece ser a mais plausível quando consideramos nossos resultados da presença de bactérias no núcleo em 13,3\% dos sialólitos.

Os conhecimentos da evolução clínica deste processo infeccioso e sua etiopatogenia são fatores preponderantes para a aplicação da terapia adequada; quanto à evolução clínica praticamente não há mais dúvidas; resta-nos detectar a causa primária da formação dos sialólitos a fim de desenvolver-se terapia preventiva e não apenas curativa.

Admitindo-se os resultados desta pesquisa poderíamos considerar a presença das mineralizações estromais associada à abundante presença de bactérias e seus produtos, via ductal, como ponto de partida.

Considerando que em glândulas salivares de pacientes saudáveis possa haver presença de micrólitos e que sialolitíase pode estar associada a outras lesões das glândulas salivares, torna-se fundamental a colaboração do cirurgião-dentista 
Discussão 90

para esses estudos, enviando qualquer peça cirúrgica removida do paciente para ser submetida à análise microscópica. 
7 CONCLUSÕES 


\section{CONCLUSÕES}

De acordo com a metodologia empregada, considerando suas limitações, observamos e concluímos que:

7.1 Os sialólitos não têm estrutura uniforme, sua morfologia varia extensivamente, não apenas no mesmo espécime como de um espécime para outro;

7.2 O padrão lamelar de organização foi predominante tanto na microscopia óptica comum quanto na microscopia de polarização;

7.3 À microscopia de luz polarizada foi possível a evidenciação mais detalhada da organização morfológica dos sialólitos;

7.4 A organização morfológica dos sialólitos pôde ser classificada por meio de luz polarizada em seis padrões distintos: linear, puntiforme, radiado, mosaico, homogêneo e misto;

7.5 A evidenciação de bactérias foi obtida em todos os espécimes, com discreta predominância das bactérias Gram-positivas, particularmente nas regiões periféricas dos espécimes;

7.6 A evidenciação de bactérias nas porções centrais de dois espécimes nos faz acreditar em seu possível envolvimento na etiopatogenia dos sialólitos. 
REFERÊNCIAS BIBLIOGRÁFICAS 


\section{REFERÊNCIAS BIBLIOGRÁFICAS*}

1 ANNEROTH, G. et al. Ultrastructure of salivary calculi. Scand. J. dent. Res., v.86, n.3, p.182-92, May 1978.

2 ANNEROTH, G.; ENEROTH, C.M.; ISACSSON, G. Crystalline structure of salivary calculi: a microradiographic and microdiffractometric study. J. oral Path., v.4, n.5, p.266-72, Nov. 1975.

3 ANNEROTH, G.; ENEROTH, C.M.; ISACSSON, G. Morphology of salivary calculi: the distribution of the inorganic component. J. oral Path., v.4, n.5 p.257-65, Nov. 1975.

4 ANNEROTH, G.; ENEROTH, C.M.; ISACSSON, G. The relation of lipids to the mineral components in salivary calculi. J. oral Path., v.6, n.6, p.373-81, Nov. 1977.

5 ANNEROTH, G.; HANSEN, L.S. Minor salivary gland calculi: a clinical and histopathological study of 49 cases. Int. J. oral Surg., v.12, n.2, p.80-9, Apr. 1983.

6 ANNEROTH, G.; ISACSSON, G.; LUNDQUIST, P. The mineral content of salivary calculi: a quantitative microradiographic and diffractometric study. Dentomaxillofac. Radiol., v.8, n.1, p.33-41, 1979.

7 AYANI, N. A multiple salivary calculi of the parotid gland. Otologia Fukuoka., v.50, p.59-62, 1978 apud TAKAHASHI, T. et al. Salivary stones. Bull Kanagawa dent. Coll., v.17, n.2, p.177-86, Sept. 1989.

8 AZAZ, B. et al. Sialolithectomy done with a $\mathrm{CO}_{2}$ laser: clinical and scintigraphic results. J. oral Maxillofac. Surg., v.54, n.6, p.685-8, June 1996.

9 BIRREFRINGÊNCIA. In: HOUAISS: dicionário da língua portuguesa. Rio de Janeiro, Objetiva, 2001. p.460.

10 BLATT, I.M. et al. Studies in sialolithiasis: I. The structure and mineralogical composition of salivary gland calculi. Ann. Otol. (St. Louis), v.67, p.595$617,1958$.

11 BODNER, L. Giant salivary gland calculi: diagnostic imaging and surgical management. Oral Surg., v.94, n.3, p. 320-3, Sept. 2002.

\footnotetext{
* Normas recomendadas para uso no âmbito da Universidade de São Paulo, com base no documento "Referências Bibliográficas: Exemplos", emanado do Conselho Supervisor do Sistema Integrado de Bibliotecas da USP, em reunião de 20 de setembro de 1990.
} 
12 BOHÓRQUEZ AVILA,S.P. Avaliação da presença e localização de bactérias nos canais radiculares e nas lesões periapicais crônicas pelo método de coloração de Brown e Breen e da Prevotella intermedia pela imunofluorescência in direta. Bauru, 1994. 128p. Dissertação (Mestrado) - Faculdade de Odontologia de Bauru, Universidade de São Paulo.

13 BOHÓRQUEZ AVILA, S.P.; ROCHA, R.S.S.; CONSOLARO, A. Avaliação da presença e localização de bactérias nos canais radiculares e nas lesões periapicais crônicas pelo método de coloração de Brown e Brenn. Rev. FOB, v.3, n.1/4, p.25-31, jan./dez. 1995.

14 BOSKEY, A.L. et al. Lipids associated with mineralization of human submandibular gland sialoliths. Arch. oral Biol., v.26, n.10, p.779-85, 1981.

15 BOSKEY, A.L.; BURSTEIN, L.S.; MANDEL, I.D. Phospholipids associated with human parotid gland sialoliths. Arch. oral Biol., v.28, n.7, p.655-7, 1983.

16 BRASILEIRO FILHO, G. Bogliolo patologia geral. 2.ed., Rio de Janeiro, Guanabara Koogan, 1998.

17 BROWN, J.H.; BRENN, L. A method for the differential staining of Grampositive and Gram-negative bacteria in tissue sections. Bull. Johns Hopk. Hosp., v.48, n.2, p.69-73, 1931.

18 BROWN, R.C.; HOPPS, H.C. Staining of bacteria in tissue sections: a reliable Gram stain method. Amer. J. clin. Path., v.59, n.2, p.234-40, Aug. 1973.

19 BURSTEIN, L.S. et al. The crystal chemistry of submandibular and parotid salivary gland stones. J. oral Pathol., v.8, n.5, p.284-91, Oct. 1979.

20 CÁLCULO. In: MACHADO, J.P. Dicionário etimológigo da língua portuguesa. Lisboa, Livros Horizonte, 1995. p.33.

21 CARR, S.J. Sialolith of unusual size and configuration. Oral Surg., v.20, n.6, p.709-12, Dec. 1965.

22 CHIODO, G.T.; ALBERT, T.W.; ROSENSTEIN, D.I. Sialoliths: review and case report. Gen. Dent., v.36, n.5, p.409-11, Sept./Oct. 1988.

$23 \mathrm{CHOI}$, J.; KIM, I.K.; OH, N.S. Multiple sialoliths in sublingual gland: report of a case. Int. J. oral Maxillofac. Surg., v.31, n.5, p.562-3, Oct. 2002.

24 CONCREÇÃO. In: MACHADO, J.P. Dicionário etimológigo da língua portuguesa. Lisboa, Livros Horizonte, 1995. p.201. 
25 CORONELLI, E.; MAFFIOLI, G.F. Calcolosi delle ghiandole salivari: note eziopatogenetiche. Rass. Trim. Odonto It., v.49, n.1, p.41-8, Jan./Mar. 1968.

26 DIFRAÇÃO. In: HOUAISS: dicionário da língua portuguesa. Rio de Janeiro, Objetiva, 2001. p.1039.

27 EKBERG, O.; ISACSSON, G. Chemical analysis of the inorganic component of human salivary duct calculi. Arch. oral Biol., v.26, n.11, p.951-3, 1981.

28 ENNEVER, J. et al. Characterization of Bacterionema Matruchotii calcification nucleator. J. dent. Res., v.57, n.4, p.637-42, Apr. 1978.

29 ENNEVER, J.; SNYDER, W.E. Mineralization of an extract obtained from filamentous micro-organisms. J. dent. Res., v.40, n.4, p.665, July/Aug. 1961.

30 ENNEVER, J.; VOGEL, J.J.; BENSON, L.A. Lipid and calculus matrix calcification in vitro. J. dent. Res., v.52, n.5, p.1056-9, Sept./Oct. 1973.

31 EPIVATIANOS, A. et al. Ultrastructural and histochemical observations on intracellular and luminal microcalculi in the feline sublingual salivary gland. J. oral Path., v.15, n.10, p.513-17, Nov. 1986.

32 EPIVATIANOS, A.; HARRISON, J.D.; DIMITRIOU, T. Ultrastructural and histochemical observations on microcalculi in chronic submandibular sialadenites. J. oral Path., v.16, n.10, p.514-7, Nov. 1987.

33 FRONDEL, C.; PRIEN, E.L. Deposition of calcium phosphates accompanying senile degeneration and disease. Science, v.103, p.326, 1946.

34 FUJII, R. et al. On the two clinical cases of salivary stone. J.Osaka Odont.Soc., v.21, p.135-6, 1958 apud TAKAHASHI, T. et al. Salivary stones. Bull Kanagawa dent. Coll., v.17, n.2, p.177-86, Sept. 1989.

35 FURSTENBERG, A.C. Diseases of the salivary glands. J. Amer. med. Ass., v.136, n.1, p.1-4, Jan. 1948.

36 GONÇALVES, M. et al. Sialolith of unusual size and shape.

Dentomaxillofac. Radiol., v.31, n.3, p.209-10, May 2002.

37 GUIRAL, H.; RISCO, J.; MAYAYO, E. Sialolithiasis submaxilar por actinomices israelii: a propósito de um caso. Ann. ORL Iber. Amer., v.25, n.3, p.247-53, 1998.

38 HAMILTON, P.H. A sialolith in the submaxillary duct: report of a case. Oral Surg., v.3, n.11, p.1388-9, 1950. 
39 HANSZEL, F. Ueber speichelsteinbildung. Wien. klin. Wochenschr., v.13, p.160-3, 1900 apud ANNEROTH, G. et al. Ultrastructure of salivary calculi. Scand. J. dent. Res., v.86, n.3, p.182-92, May 1978.

40 HARRILL, J.A. et al. Structure and composition of salivary calculi. Laryngoscope, v.69, n.5, p.481-92, May 1959.

41 HARRISON, J.D. et al. Histochemical and biochemical determination of calcium in salivary glands with particular reference to chronic submandibular sialadenites. Virchows Arch. A. Path. Anat., v.423, n.1, p.29-32, 1993.

42 HARRISON, J.D.; EPIVATIANOS, A.; BHATIA, S.N. Role of microliths in the aetiology of chronic submandibular sialadenites: a clinicopathological investigation of 154 cases. Histopathology, v.31, n.3, p.237-51, Sept. 1997.

43 HIRAIDE, F.; NOMURA, Y. The fine surface structure and composition of salivary calculi. Laryngoscope, v.90, n.1, p.152-8, Jan. 1980.

44 HOBKIRK, J.A. Sialolithiasis of a minor salivary gland: a case report and review of the literature. Dent. Practit. dent. Rec., v.20, n.6, p.213-4, Feb. 1970.

45 HÖHLING, H.J.; SCHÖPFER, H. Morphological investigations of apatitic nucleation in hard tissue and salivary stone formation.

Naturwissenschaften, v.55, n.11, p.545, Nov. 1968.

46 HO, V.; CURRIE, W.J.R.; WALKER, A. Sialolithiasis of minor salivary glands.

Brit. J. oral Maxillofac. Surg., v.30, n.4, p.273-5, Aug. 1992.

47 HUBAR, J.S. et al. Megalith. Oral Surg., v.70, n.2, p.245, Aug. 1990.

48 HUGHES, P.M. et al. Scintigraphic evaluation of sialadenitis. Brit. J. Radiol., v.67, n.796, p.328-31, Apr. 1994.

49 HVIDT, R. Sialolithiasis. Ugeskr. Laeg., v.123, p.98-101, 1961 apud ANNEROTH, G. et al. Ultrastructure of salivary calculi. Scand. J. dent. Res., v.86, n.3, p.182-92, May 1978.

$50 \mathrm{IRO}, \mathrm{H}$. et al. Extracorporeal shockwave lithotripsy of salivary gland stones. Lancet, v.2, n.8654, p.115, July 1989.

51 ISACSSON, G. Salivary calculi. Stockholm, 1977. 31p. Dissertação (Mestrado) - Karolinska Institute and Department of Oto-rhino-laryngology, Karolinska Hospital. 
52 ISACSSON, G. et al. Salivary calculi and chronic sialadenites of the submandibular gland: a radiographic and histologic study. Oral Surg., v.58, n.5, p.622-7, Nov. 1984.

53 ISACSSON, G.; AHLNER, B.; LUNDQUIST, P.G. Chronic sialadenites of the submandibular gland: a retrospective study of 108 cases. Arch.

Otorhinolaryngol., v.232, n.1, p.91-100, 1981.

54 ISACSSON, G.; FRISKOPP, J. The morphology of salivary calculi: a scanning electron microscopic study. Acta odont. scand., v.42, n.2, p.65-72, Apr. 1984.

55 ISACSSON, G.; HAMMARSTRÖM, L. An enzyme histochemical of human salivary duct calculi. J. oral Path., v.12, n.3, p.217-22, June 1983.

56 ISACSSON, G.; LUNDQUIST, P.G. Salivary calculi as an aetiological factor in chronic sialadenitis of the submandibular gland. Clin. Otolaryngol., v.7, n.4, p.231-6, Aug. 1982.

57 JENSEN, A.T.; DANO, M. X-ray crystallographic examination of calculi from salivary glands. J. dent. Res., v.31, p.620-6, 1952.

58 JENSEN, J.L. et al. Minor salivary gland calculi: a clinicopathologic study of forty-seven new cases. Oral Surg., v.47, n.1, p.44-50, Jan. 1979.

59 KINNI, M.E. Sialolith. Oral Surg., v.59, n.1, p.111, Jan. 1985.

60 KLEBS, E. Beiträge zür kenntnis der pathogenen schistomyceten. Arch. exp. Path., v.5, p.350-77, 1876 apud ANNEROTH, G. et al. Ultrastructure of salivary calculi. Scand. J. dent. Res., v.86, n.3, p.182-92, May 1978.

61 KÜTTNER, H., Handbuch der praktischen crururgie. Stuttgart, Verlag von Ferdinand Enke, p.927-35, 1926 apud TAKAHASHI, T. et al. Salivary stones. Bull Kanagawa dent. Coll., v.17, n.2, p.177-86, Sept. 1989.

62 KÜTTNER, H. Ueber entzündliche tumoren der submaxillar-speicheldrüse. Beitr. Klin. Chir., v.15, p.815-28, 1896 apud HARRISON, J.D.; EPIVATIANOS, A.; BHATIA, S.N. Role of microliths in the aetiology of chronic submandibular sialadenites: a clinicopathological investigation of 154 cases. Histopathology, v.31, n.3, p.237-51, Sept. 1997.

63 LAFORGIA, P.D. et al. Analisi clinico-statistica, morfologica e microstruturale di 400 casi di sialolitiasi. Minerva Stomatol., v.38, n.12, p.1329-36, Dec. 1989.

64 LANDIS, J.R.; KOCH, G.G. The measurement of observer agreement for categorical data. Biometrics, v.33, n.1, p.159-74, Mar. 1977. 
65 LEUNG, A.K.C. et al. Multiple sialoliths and a sialolith of unusual size in the submandibular duct: a case report. Oral Surg., v.87, n.3, p.331-3, Mar. 1999.

66 LEVY, D.M.; REMINE, W.H.; DEVINE, K.D. Salivary gland calculi: pain, swelling associated with eating. J. Amer. med. Ass., v.181, n.13, p.1115-9, July/Sept. 1962.

67 LIMA, V.A. et al. Sialolitíase submandibular: análise clínica de 188 casos. Rev. Col. bras. Cir., v.9, n.2, p.41-4, mar./abr. 1982.

68 LITÍASE. In: MACHADO, J.P. Dicionário etimológigo da língua portuguesa. Lisboa, Livros Horizonte, 1995. p.430.

69 LUSTMANN, J.; REGEV, E.; MELAMED, Y. Sialolithiasis: a survey on 245 patients and a review of the literature. Int. J. oral Maxillofac. Surg., v.19, n.3, p.135-8, June 1990.

70 LUSTMANN, J.; SHTEYER, A. Salivary calculi: ultrastructural morphology and bacterial etiology. J. dent. Res., v.60, n.8, p.1386-95, Aug. 1981.

71 MANDEL, I.D.; EISENSTEIN, A. Lipids in human salivary secretions and salivary calculus. Arch. oral Biol., v.14, n.2, p.231-3, Feb. 1969.

72 MANDEL, L.; FATEHI, J. Minor salivary gland sialolithiasis: review and case report. N. Y. St. dent. J., v.58, n.10, p.31-3, Dec. 1992.

73 MARCHAL, F. et al. Retrograde theory in sialolithiasis formation. Arch. Otolaryng. Head Neck Surg., v.127, n.1, p.66-8, Jan. 2001.

74 MARCHAL, F. et al. Submandibular diagnostic and interventional sialendoscopy: new procedure for ductal disorders. Ann. Otol. Rhinol. Laryngol., v.111, n.1, p.27-35, Jan. 2002.

75 MCCONNELL, D. The crystal chemistry of carbonate apatites and their relationship to the composition of calcified tissues. J. dent. Res., v.31, p.53-63, 1952.

76 MISHIMA, H.; YAMAMOTO, H.; SAKAE, T. Scanning electron microscopy: energy dispersive spectroscopy and x-ray diffraction analyses of human salivary stones. Scan. Microscopy, v.6, n.2, p.487-94, June 1992.

77 NAESLUND, C. A comparative study of the formation of concretions in the oral cavity and in the salivary glands and ducts. Dent. Cosmos, v.68, p.113744, 1926.

78 NAHLIELI, O.; BARUCHIN, A.M. Sialoendoscopy: three years experience as a diagnostic and treatment modality. J. oral Maxillofac. Surg., v.55, n.9, p.912-8, Sept. 1997. 
79 NAHLIELI, O. et al. Combined approach to impacted parotid stones. J. oral Maxillofac. Surg., v.60, n.12, p.1418-23, Dec. 2002.

80 NEVILLE, B.W. et al. Patologia oral e maxilofacial. Rio de Janeiro, Guanabara Koogan, 1998.

81 NEW, G.B.; HARPER, F.R. Chronic inflammation of the salivary glands with or without calculi. Surg. Gynecol. Obstet., v.53, p.456-60, 1931.

82 NG, S.Y.; PINTO, P. Ultrasound-guided retrieval of labial minor salivary gland sialoliths. Dentomaxillofac. Radiol., v.29, n.5, p.319-22, Sept. 2000.

83 NILES, E.S. A study of the salivary glands with reference to the cause of odontolithus. Dent. Cosmos, v.26, p.466-84, 1884.

84 PAPIN, D. Salivary calculus. Dent. Cosmos, v.6, p.136, 1864-65.

85 PILCHER, J.A. Salivary calculus containing a foreign body: report of a case. Arch. Otolaryngol., v.26, p.531-3, 1937.

86 POLLACK, C.V.; SEVERANCE, H.W. Sialolithiasis: case studies and review. J. Emerg. med., v.8, n.5, p.561-5, Sept./Oct. 1990.

87 PRATT, L.W. Foreign body of Wharton's duct with calculus formation. Ann. Otol. Rhinol. Laryngol., v.77, n.1, p.88-93, Feb. 1968.

88 PTIÁLITO. In: MACHADO, J.P. Dicionário etimológigo da língua portuguesa. Lisboa, Livros Horizonte, 1995. p.456.

89 PULLON, P.A.; MILLER, A.S. Sialolithiasis of accessory salivary g lands: review of 55 cases. J. oral Surg., v.30, n.11, p.832-4, Nov. 1972.

90 RABINOV, J.D. Imaging of salivary gland pathology. Radiol. clin. North Amer., v.38, n.5, p.1047-57, Sept. 2000.

91 REFRAÇÃO. In: HOUAISS: dicionário da língua portuguesa. Rio de Janeiro, Objetiva, 2001. p.2413.

92 REICHART, P.A.; PHILIPSEN, H.P. Patologia Bucal. Porto Alegre, Artmed, 2000.

93 RICE, D.H. Advances in diagnosis and management of salivary gland diseases. West J. Med., v.140, n.2, p.238-49, Feb. 1984.

94 RIBEIRO, F.C. Aspectos morfológicos dos biofilmes microbianos na osteomielite crônica supurativa e correlações endodôntica e parendodôntica. Bauru, 1999. 128p. Tese (Doutorado) - Faculdade de Odontologia de Bauru, Universidade de São Paulo. 
95 RIESCO, J.M. et al. Crystalloid architecture of a sialolith in a minor salivary gland. J. oral Path. Med., v.28, n.10, p.451-5, Nov. 1999.

96 RISAK, E. Zur frage der speichelsteinkrankheit. Zentralbl. chir., v.56, p.2464, 1929 apud ANNEROTH, G. et al. Ultrastructure of salivary calculi. Scand. J. dent. Res., v.86, n.3, p.182-92, May 1978.

97 RIZZO, A.A. et al. Mineralization of bacteria. Science, v.135, p.439-41, 1962.

98 RODGERS, A.; SPECTOR, M. Human stones. Endeavour, v.5, n.3, p.11926, 1981.

99 RUST, T.A.; MESSERLY, C.D. Oddities of salivary calculi. Oral Surg., v.28, n.6, p.862-5, Dec. 1969.

100 SAKAE, T.; YAMAMOTO, H.; HIRAI, G. Mode of occurrence of brushite and whitlockite in a sialolith. J. dent. Res., v.60, n.4, p.842-4, Apr. 1981.

101 SCHERER. 1737 apud TAKAHASHI, T. et al. Salivary stones. Bull Kanagawa dent. Coll., v.17, n.2, p.177-86, 1989.

102 SCHMELZEISEN, R. et al. Sonography and scintigraphy in the diagnosis of diseases of the major salivary glands. J. oral Maxillofac. Surg., v.49, n.8, p.798-803, Aug. 1991.

103 SCHROEDER, H.E.; BAMBAUER, H.U. Stages of calcium phosphate crystalisation during calculus formation. Arch. oral Biol., v.11, n.1, p.1-14, Jan 1966.

104 SCHROEDER, H.E. Formation and inhibition of dental calculus. J. Periodontol., v.40, n.11, p.643-6, Nov. 1969.

105 SEIFERT, G. Aetiological and histological classification of sialadenites. Pathologica, v.89, n.1, p.7-17, Feb. 1997.

106 SHAFER, W.G. et al. Tratado de patologia bucal. 2 ed. Rio de Janeiro, Interamericana, 1985.

107 SHINOHARA, Y. et al. Sialolithiasis in children: report of four cases. Dentomaxillofac. Radiol., v.25, n.1, p.48-50, Jan. 1996.

108 SIALÓLITO. In: MACHADO, J.P. Dicionário etimológigo da língua portuguesa. Lisboa, Livros Horizonte, 1995. p.192.

109 SIALÓLITO. In: HOUAISS: dicionário da língua portuguesa. Rio de Janeiro, Objetiva, 2001. p.2565.

110 SIDDIQUI, S.J. Sialolithiasis: an unusually large submandibular salivary stone. Brit. Dent. Journal, v.193, n.2, p.89-91, July 2002. 
111 SLOMIANY, B.L. et al. Lipid composition of the matrix of human submandibular salivary gland stones. Arch. oral Biol., v.27, n.8, p.673-7, 1982.

112 SODERLUNG, G. Die speichsteinkrankheit (sialolithiasis) und ihr veralten zu der priaaren und duktogene speicheldrusen aktinomycose. Ztble. Chir., v.38, p.24141-30, 1930 apud TAKAHASHI, T. et al. Salivary stones. Bull Kanagawa dent. Coll., v.17, n.2, p.177-86, Sept. 1989.

113 STANLEY, M.W. et al. Sialolithiasis: differential diagnostic problems in fineneedle aspiration cytology. Anat. Pathol., v.106, n.2, p.229-33, Aug. 1996.

114 TAKAHASHI, T. et al. Salivary stones. Bull Kanagawa dent. Coll., v.17, n.2, p.177-86, Sept. 1989.

115 TAKEDA, Y. Crystalloids with calcareous deposition in the parotid gland: one of the possible causes of development of salivary calculi. J Oral Pathol, v.15, n.8, p.459-61, Sept. 1986.

116 TAKEDA, Y.; ISHIKAWA, G. Crystalloids in salivary duct cysts of the human parotid gland: scanning electron microscopical study with electron probe $X-$ ray microanalysis. Virchows Arch., v.399, n.1, p.41-8, 1983.

117 TANDLER, B. Electron microscopical observations on early sialoliths in a human submaxillary gland. Arch. oral Biol., v.10, n.3, p.509-22, May/June 1965.

118 TARTARO, S. et al. Contributo clinico-casistico sulla calcolosi delle ghiandole salivari. Arch. Stomat., v.22, n.3, p.325-47, July/Sept. 1981.

119 TAYLOR, R.D. Modification of the Brown and Brenn Gram stain for the differential staining of Gram-positive and Gram-negative bacteria in tissue sections. Amer. J. clin. Path., v.46, n.4, p.472-4, Oct. 1966.

120 TEYMOORTASH, A. et al. Bacteria and pathogenesis of human salivary calculus. Acta Otol., v.122, n.2, p.210-4, Mar. 2002.

121 TRAINI, T. et al. Analisi al SEM ed al microscopio ottico in luce polarizzata di uno scialolita della ghiandola sottomandibolare. Minerva Stomatol., v.50, n.5, p.173-80, May 2001.

122 TRIANTAFYLLOU, A.; HARRISON, J.D.; GARRETT, J.R. Analytical ultrastructural investigation of microliths in salivary glands of cat. Histochemical J., v.25, n.3, p.183-90, Mar. 1993.

123 VIDAL, B.C.; MELLO, M.L.S.. Biologia celular. Rio de Janeiro, Livraria Atheneu, 1987. 
124 VITUMS, V.C. Sialolith simulating a cuspid. Oral Surg., v.32, n.3, p.503, Sept. 1971.

125 WAKELEY, C.P.G. The formation of salivary calculi and their treatment. Lancet, v.216, p.708-11, 1929.

126 YUASA, K. et al. Submandibular gland duct endoscopy: diagnostic value for salivary duct disorders in comparison to conventional radiography, sialography and ultrasonography. Oral Surg., v.84, n.5, p.578-81, Nov. 1997.

127 ZENK, J.; HOSEMANN, W.G.; IRO, H. Diameters of the main excretory ducts of the human submandibular and parotid gland. Oral Surg., v.85, n.5, p.576-80, May 1998. 
ABSTRACT 


\section{ABSTRACT \\ MORPHOLOGIC ANALYSIS AND SIALOLITHS STUDY \\ BY MEANS OF THE \\ OPTICAL AND POLARIZATION MICROSCOPIES}

The purpose was to analyze sialoliths through optical microscopy and of polarizated light. It was going used 15 cases, whose blocks, foils and records of the specimens were obtained from of the Department of Oral Pathology, Bauru Dental School, of São Paulo University. Under the optical microscopy the specimens were analyzed through hematoxylin-eosin and Brown and Brenn stains. It was observed that the sialoliths has no uniform structure, and their morphology varies not just in the same specimen but also from a specimen to another. The lamellar pattern of organization was as predominant at the optical microscope as at the polarized light microscope. There was detected of bacteria in all the specimens. Through polarized light it was established a classification for the found patterns: lineal, speck, mosaic, radiated, homogeneous and mixed. In the specimens that presented soft tissue $(26,6 \%$ of the sample) it was detected speck shape stromals mineralization. 
APÊNDICES 


\section{Universidade de São Paulo Faculdade de Odontologia de Bauru}

Al. Dr. Octávio Pinheiro Brisolla, 9-75 - Bauru-SP-CEP 17012-901 - C.P. 73

PABX (0XX14)235-8000 - FAX (0XX14)223-4679

Comitê de Ética em Pesquisa

Processo $n^{\circ} 010 / 2003$

Bauru, 6 de março de 2003

Senhor Professor,

O projeto de pesquisa encaminhado a este Comitê de Ética em Pesquisa em Seres Humanos, denominado "Sialólitos: análise morfológica e estudo através de microscopia óptica e de polarização", de autoria de Rosário de Arruda Moura Zedebski, que será desenvolvido sob sua orientação, foi enviado ao relator para avaliação.

$\mathrm{Na}$ reunião de 26 de fevereiro de 2003 , o parecer do relator, aprovando o projeto, foi aceito pelo Comitê, considerando que não existem infrações éticas pendentes

Informamos que após o envio do trabalho concluído, este Comitê enviará o parecer final, que será utilizado para publicação do trabalho.

Atenciosamente,

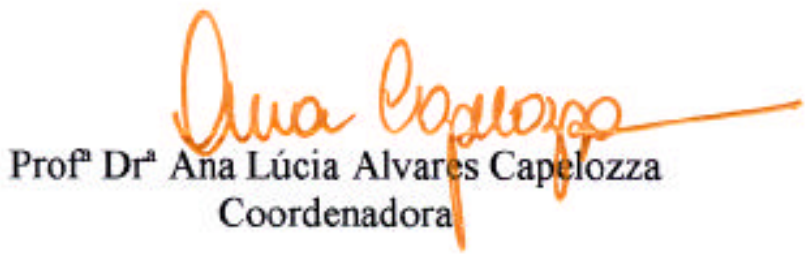

$\mathrm{Ilm}^{\circ} \mathrm{Sr}$. Prof. Dr. Luís Antônio de Assis Taveira

DD. Docente do Departamento de Estomatologia 


\section{Universidade de São Paulo \\ Faculdade de Odontologia de Bauru}

Al. Dr. Octávio Pinheiro Brisolla, 9-75 - Bauru-SP - CEP 17012-901 - C.P. 73

PABX (0XX14)235-8000 - FAX (0XX14)223-4679

Comitê de Ética em Pesquisa

Processo $n^{\circ} 010 / 2003$

Bauru, 30 de abril de 2003

Senhor Professor,

Informamos que após análise por este Comitê de Ética em Pesquisa em Seres Humanos, seu pedido de alteração do titulo do projeto de pesquisa intitulado "Sialólitos: análise morfológica e estudo através de microscopia óptica e de polarização" de autoria da $\mathrm{CD}$. Rosărio de Arruda Moura Zedebski, sob a sua orientação, para "Anâlise morfológica e estudo dos sialólitos por meio das microscopias óptica e de polarização", foi aprovado.

Lembramos que após o envio do trabalho concluído, este Comitê enviará o parecer final, que será utilizado para a publicação do trabalho.

Atenciosamente,

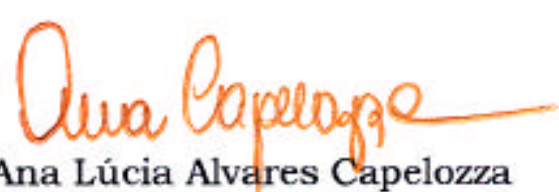

Prof ${ }^{2} \mathrm{Dr}^{2}$ Ana Lúcia Alvares Capelozza

Coordenadora do Comitê de Ética em Pesquisa em Seres Humanos

$\mathrm{Ilm}^{\circ} \mathrm{Sr}$. Prof. Dr. Luis Antônio de Assis Taveira

DD. Docente do Departamento de Estomatologia (Patologia) 